Portland State University

PDXScholar

6-1-1966

\title{
Unmet social work needs in an inmate population of a county correctional institution
}

Jerry M. Harkins

Portland State University

Melbourne W. Henry

Portland State University

Virginia J. Hodges

Portland State University

Mary Patrick O'Meara

Portland State University

Elisabeth N. Siegel

Portland State University

See next page for additional authors

Follow this and additional works at: https://pdxscholar.library.pdx.edu/open_access_etds Let us know how access to this document benefits you.

\section{Recommended Citation}

Harkins, Jerry M.; Henry, Melbourne W.; Hodges, Virginia J.; O'Meara, Mary Patrick; Siegel, Elisabeth N.; and Wilkins, Donna B., "Unmet social work needs in an inmate population of a county correctional institution" (1966). Dissertations and Theses. Paper 506.

https://doi.org/10.15760/etd.506

This Thesis is brought to you for free and open access. It has been accepted for inclusion in Dissertations and Theses by an authorized administrator of PDXScholar. Please contact us if we can make this document more accessible: pdxscholar@pdx.edu. 


\section{Author}

Jerry M. Harkins, Melbourne W. Henry, Virginia J. Hodges, Mary Patrick O'Meara, Elisabeth N. Siegel, and Donna B. Wilkins 
AN ABSTHACT OF THE THESIS OR

Herkins, J.M., et al. for the Masters in Soclal Work Date thesis is presented Hay 13, 1966

Title Unmet Social Work Needs in an Inmate Population of a County Correctional Institution

Abstract approved

This descriptive study was designed to elic1t the kInds, extensity and intensity of needs of the inmate population of Multnomah County Correctional Institution. 2 minimum security jall for misdemeanants.

A guiding hypothes18 asserted that there were unmet needs of prisoners which could be met through social work services both within and outside the institution.

Almost the entire population of the institution was Interv1ewed. Open-end and structured responses were recorded on schedules. Flve broad seas of need were defined. These were 1) physical needs - Including sood, clothing, shelfer, and medical care; 2$)$ social needs .. including interpersoral ties, group membership, religious, and recreationa 1 needs; 3) psychological needs -- including the Individual $\mathrm{g}$ self concept, attltudes towards accepting he1p, desire for change, and his present level of achieve. ment versus level of spiration; 4) educational needs -Iroluding academic, vocational, or remedial schooling: 
ard 5) ilnancial needs - - including post-release funds, debts, and employment.

Statistical measures tested consistency, whether 1ntervlewers projected their own values, and interviewer reliability. Variances showed differences were due mostly to Inmate traits and not interviewer bias, except that the welght given to some inmate needs varied more than chance at the .05 level.

The 59 men saw themselves as having some 102 cotem gorlaed needs immediate upon release and 320 long-range needs, nearly all directly xelated to social work serviees.

Findings suggested additional research in the Bollowing areas:

1. To determine the similarity or dissimilartty of inmate needs of misdemeanants elsewhere.

2. To determine to what extent commun1ty resources can be made avaliable in responding to the needs of released prisoners.

3. To determine family needs of Inmates. Implications of the study favored the use of social warers within the institution itself, evaluation of existo Ing soclal work seryices, the establishment of a jobmplace. ment program and crention of down-town center to serve 2. number of secular needs. 
APPROVED:

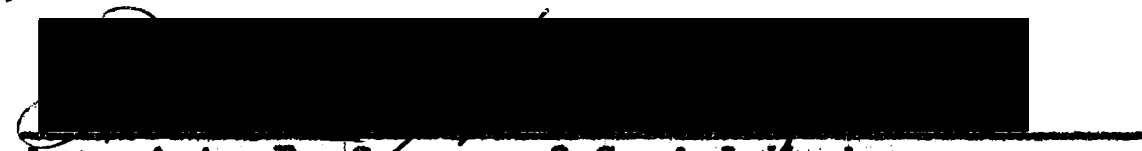
Associate Professor of Soclal Work
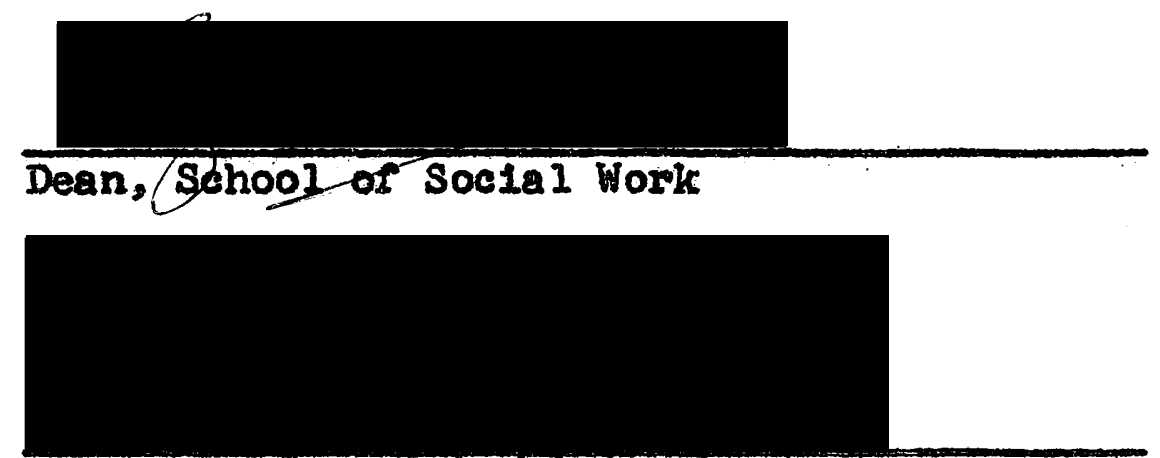

Dean of Graduate strgies

Date thesis is presented

May 13, 1966

Typed by Keitha He12B 


\section{Oregon. State College, Portland. School of Social Work.}

ONRET SOCIAL WORR NEEDS IN AN INAMTE

POPULATION OF A COUNTY CORRECTIONAL INSTITUTION

by

JERRY M. HARKINS

MELBOURRE W. HENRY

VIRGINIA J HODGES

SISTER MARY PATRICK O'MEARA

FIISABETH $N$ 。 SIEGEL

DONNA B。WIIKINS

A GROUP PROJECT

submitted to

PORTLAAND STATE COLTEGE

in pertial fulfiliment of

the requirements for the

degree of

HASTER OP sOCIAL HORK

June 1966 


\section{TABLE OR CONTENTS}

CIA PISER

I. TMIRODUCTION

Ratlonale.................. 3

Researchers a.................. 4

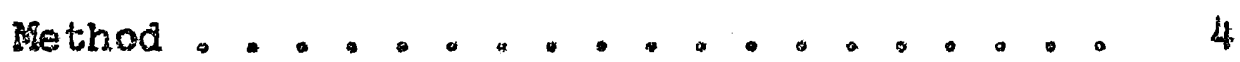

Limications................. 5

Hypothesis................ 5

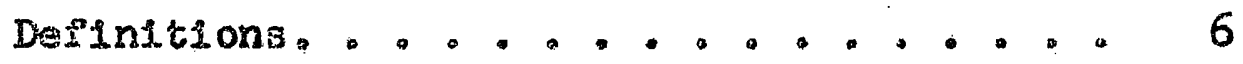

Operating Definitions.......... 9

Corrections............ .10

Notes.................. 19

IX, SETTHNG: IULTWOAAH COUNTУ AND ITS CORRECTIONAI INSTTIUTION

The Offlee of Sherlif............20

Rocky Buttra11............. 23

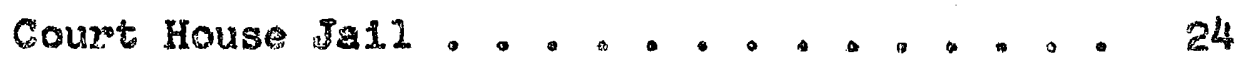

Mulnomen Courity Correctional Institution

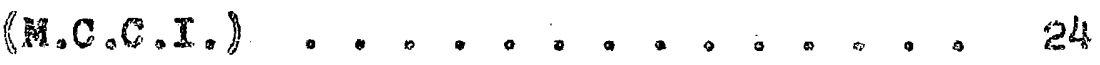

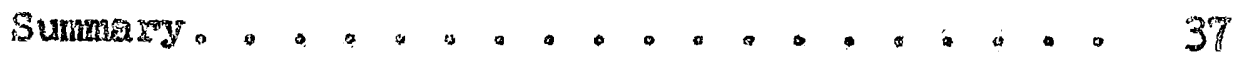

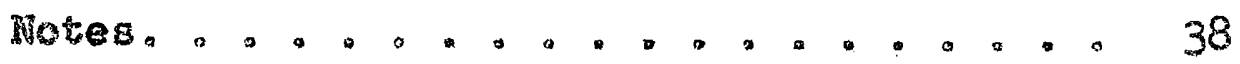

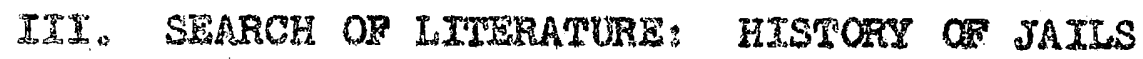

Criteria for Searh of ilterature..... 39

Tolution of Cximinal Ion. .........40 
Origin of ga11s............ 43

Origin of Correctional Institutions. . . 46

History Felated to Project . . . . . " 48

Notes.............. 51

IV. SEARCH OF LITERATURE: CURRENT STUDIES IN CORRECTIONS

Theories of Criminology. ........ 52

Need Concepts in Soclal Work ....... 59

Special Areas of Need. ......... 63

Role of Social. Work. ......... 67

Comuntty Resources. ......... 73

Conclustons. ............. 74

Notes. . .............. 76

V. METHODOLOAY

Cenera I Procedure, ........... 80

Dallaniting the Problem .......... 83

Hypotheses . ........... 85

Prentest Interviews. . . . . . . 86

Construction of the Questionnare..... 89

Cxiteria for Selection of Interviewees... 92

Adminiatretion of the Questionnalre....93

Tabulation of Data ............ 95

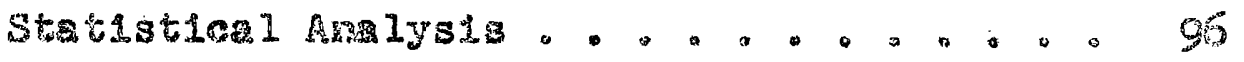


VI. FINDINGS: DESCRIPTIVE

Demographic Datr. ........... 99 Employment and Income Dato ........ 102 Marital and Farental Ststus of Inmate Population............ 105 Needs of Inmate Population ....... 106 Self-Concept of Inmates.......... 118 Iny tes Loners. . . . . . . . . a 121 Thme Feelings about H.C.C.I. . . .... 124 Fost-Release Plans . . . . . . . . . 125

VII. FINDINGS: IREEREMTIRI

Pnysleal Needs . . . . . . . . 128 Soclal Meeds............... 129 Esychologida I Needs. . . . . . . 130 Focatoral Meeda. ........... 134 Flnancial Heeds. ............. 135 Statistigal Analysis of Job Needs...... 136 Surengry. ............... 140

VITI. ENELUUATYON AND IMPLICATIONS

Critique of the Questlonnalre....... 142 Relationship to the LIterature ..... 148 Traplications ............... 152 sunnow. . . . . . . . . . . 157 
DX. SURUARY ARD SUGGESTIONS FOR FUTURE STUDIES

Reconmendations for Puture Research and

$$
\text { Action ............... } 160
$$

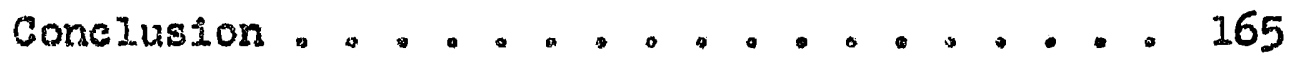

Motes............... 167

Selected Blbliography. .......... 168

Appendix A - Questionnalre . . . . . 176

Appendix B - Tebuletion.......... 190

Appendix C - Charts. ........... 200 
CHA PTER I

\section{INZRODUCTION}

Th1s was a descriptive study. The purpose was to determine the k1nds, frequeney, and intensity of needs confronting varlous types of offenders who were at one point in time part of the inmate population of Muitnomah County Correctional Institution, hereafter referred to as H.C.C.I. Particular emphas1s was placed upon personal and famliy needs that would confront the inmate subsequent to his release from the institution. These needs included both Imrediate and future wants of the inmates. Signiflcant secondary findings were seen as possible outgrowths. As a forward-10oking project, the study anticipated exfective reduction of societal and personel pressures which lead men to comrat felonies and misdemeanors by making avallable to the potential prizoner and/or recldivist community resources which he could use in thes of stress and need. Th1s purpose has particular significance for inmates In Rultnomah County because of the lack of a county parole or probation system which might act as an information bureau for those in need. However, inmates who are serving sentences of more than six months may apply for Parole through the Oregon State Parole and Probation Department.

This project was undertaken with expectations of pioviding service-oriented agencies in the Portland area 
with indications and suggestions which would help them channel their errergles toward the specific needs of shortterm prisoners upon release from jalla and correctiona 1 institutions. Results may show greatex strength in agencles already involved in rehabilitation of released prisoners and may be the catalyst in synthesizing and coordingting the services of existing social services. Another of the secondary expectations was to gather materials for a future booklet to be published for the use of Inmates, arrestees, police and correctional personnel. Th1s booklet would point to the existence of social services now giving limited attention to the unmet needs of exmprisoners and the 1.r families.

In general, it was hoped that the conclusions would stimulate greater public interest, awareness and concern in the universal field of correction with special applica. tion to the County of Multnomah.

This project did not purport to point up the positive possiblities of keeping more men from beconing recidivists because of their experience in the experimental Pacil1ty demonstrated at a gudy ar crime prevention, nor was it geared to help the pexisons currently serving time. It was not intended to 2leviate the needs of the present inmate population. Although some judgmental, Interpretive observations were included, it was not the purpose of the researchers to 
evaluate the Institution as such.

Rationale

The rationale underlying this study grew out of a number of salient points pertinent to the general field of ja1ls.

1. The majority of correctional subjects are in the jail population.

2. The ja1ls have long been neglected as objects of research.

3. The high recidivism rate, the poor conditions, the inhumane treatment of prisoners, and the overcrowding would indicate that jalls have not been successful in meeting their purpose.

4. Ja1ls have been neglected by soclal agencies .

5. There is a recent resurgence of interest in jails as a matrix of crime.

The concept for this project grew out of an educational conference on corrections held in Portland, Oregon, In 1964. Subsequently, Dr. Frank Miles of the Research Department of the School of Soclal Work of Portland State College approached Sheriff Donald E. Clark asking for cooperation and direction on the possibility of special research at the new correctional institution of Multnomah County. It was agreed that M.C.C.I. and Its inmate population would provide the data. 
Researchers

Intitally, it was recommended by the project director that the research be carrled out by ten or more individuals who had detalled knowledge of community resources and possible experience in the fleld of corrections. Several students expressed keen interest in the proposed study; however, only eight members elected to participate in the project, but two of these withdrew from the Graduate School at the end of the first year.

The project was finaliy undertaken by six students of varying backgrounds under the direction of Dr. Frank Miles, project director. Among these six students, one had a background in the Children's Department of Public Welfare and In a private ageney with unwed mothers; another worked as a caseworker and supervisor in the State Public Welfare Department; one had several years juvenile court work; one had limited experience in religlous services with prisoners; one served as Director of Girls in a private correctional agency; and still another had done volunteer service with alcoholic groups.

Method

Sixty inmates were interviewed with questionnalres prepared by the researchers. Each student interviewed ten inmates. The inmates were asked 73 structured questions * See Appendix page 176 
and their responses were $x^{\circ}$ ecorded by the intervlewers. These questions were geared to ascertain the needs of the men as the men saw them. Interviews were held on an individua I basis in private offices at the institution itself.

\section{Limitations}

1. Because the inmate population at M.C.C.I. represents only a smali portion of all inmaties in the state of Oregon, generalizations to other areas or populations should be drawn cautlously.

2. Although M.C.C.I. as a minimum security institution and the current inmate population represented a select group from Rocky Butte the mof county jali which w111 be described later), who were assumed to be more highly motivated and amenable to treatment than the average prisoner in the state of Oregon, the needs deternined by this study could represent the unmet needs of 11 prisoners.

3. The one-time contact with the prisoners did not faclittate as free a commication as could have been ganed from several contacts.

Hypothesis

This study is predicated upon one major hypothests. If states that there are unmet needs of prisoners which could be set through soclal work services both within and outside the institution. 
The Nul1 Hypothesis states that there is no signif lcant relationsin between the unmet needs of prisoners and the social work services which could be provided to meet them.

\section{Definttions}

The following derinitions attempt to provide expanded background information pertinent to an understanding of this study. These definitions, in part, give denotativa and connotative usage of the words. The operating definitions will be discussed later in this chapter.

Misdemeanor: There is no clear-cut or precise derinition for the term "misdemeanor". Generally, the term applies to persons legally convicted of a crime not classiried as a felony. Felonlous acts are usually clearly deflned by individual states; however, crimes which constitute a felony in one state may not be a felony in another state. Therefore, the term mademeanor depends on the law or a given state, county, or municipality for 1ts defirition.

Usually, persons sentenced for misdemeanors are tried by a local maglstrate, district courts, or justice of the peace ard committed to local city or county ja11s state fams, houses of corrections, work houses, or road camps. Genera $11 y^{2}$ misdemeanants incur shorter sentences and lesser flnes than those given to felors; however, in some atates certa In misdemeanors draw down a heavier sentence than a 
minor felony. A misdemeanor confinement normally ranges in duration from a few days to several months, and does not usually exceed one year.

The most frequent charges which result in misdemeanor confinement are drunkennesi, disorderly conduct, vagrancy, non-support of dependents, assault and battery, petty larceny, gambling, and driving offenses.

In the State of Oregon, a definition of the term misdemeanor may be found in the Oregon Revised Statutes (1963). It reads as follows:

"161.080. Misdemeanors: punishment when penalty not prescribed. Whenever an act is declared to be a misdemeanor and no punishment is prescribed therefore, the person committing the act shall be punished upon conviction by imprisonment in the county jail for not more than one year or by fine of not more than $\$ 500$, or both."

Ia11: The word fall (British-gaol) is thought at one point to be derived from the Spanish laulu-a-cage. It is place for confinement of persons arrested for crimes and held in custody.

In defining the term fail, Louls N. Robinson sa1d:

"A jail is a local penal institution, county or city, for the safe-keepling of persons awalting trial but not admitted to ba11, and in general for those serving short sentences of less than one year. There are other groups who pass through the jail. It is customary to keep in jail important witnesses who, it is thought, might disappear; and insane individus Is are often held in jail pending their transfer to a hospital...

"The use that is made of a ja1.l depends 
upon the avaliablitity of sita and other county or municipal Institutions, upon the extent to which probltion is used, and upon the functioning of court machinery. (1)

Each state has its oun legislation pertinent to the creation and malntenance of a jall system. As can be expected, the rules and regulations for each state are different and quite often serve the political interest of the law makers.

Genera 1Iy, short-term prisoner may be defined as one who has been found guilty of a misdemeanor or selony and commitied to a local or reglonal jail or correctiona institution for a period not usualiy exceeding one year.

Need: As defined by Webster's New World Dictionary, the term "need" refer's to an urgent requirement of something essential, or desirable that 1s lacking, required or destred. A need also represents a condition in which there is a deflelency of something requiring relies or supply. A need is a condition of poverty or state of want.

The term "need" is used quite frequently in psychom blologic 11terature in reference to man's survival both as an animal and as a member of society. The study of behavior In many species, both internal and external, makes it possible to ldentify certain patterns of activity that are geared toward mintaining the lise adaptation of individual members within a species. For example, we know that the 
are certain blologic requirements of organtsms, such as oxygen, food, water, elimination of waste products, and protection Irom hostile environments. Behavior then, will take place to meet the above requirements. The type of behavior performed is referred to as an adaptation and the requirement to be satisfied is called a need.

Operating Definttions

Semantic difficulties frequently interfere with effective communication. The following definitions of terms are given to prevent possible misinterpretation. Social Works This refers to help offered by a professionel social worker to instigate the process by which the client is alded in adapting to his ilfe situa. tion perticularly with regard to his interaction with the communt ty at large.

Soc1al Work Ageney: This term refers to those agencies in and around the metropolitan area of Portiand. It includes, but is not limited to, those socim I agencies which offer services to both the person and his family.

Need: In this project the word need refers to those 1tens listed on the questionnaire stated by the 1nm mate as essential or desirable that are lacking, required, and desired in his particular case.

Communtey Organizations: These refer to any educaclone 1, recreatlonal, religious, hed th, or welfare 
organization.

Inmate or Prisoner: Th1s refers to men incarcerated in the county jail for a misdemeanor, with a sentence of one year or less on each charge.

Intensity: This term refers to the degree or amount of strength or energy with which the need is felt by the Inmate.

Extensity: This term refers to the breadth of the need and Indicates how much of a need is present in the group or Individual.

Corrections

This study was called the "Corrections Project". The word "corrections" is not merely a euphentstic expression to cover up an old problem, but it is a genuine attempt to take a new approach to the old problems of criminals, punishments, and prisons. Th1s new approach 1deally sees man as a total belng--blological, soclological, psychological and spipitualmand as such, treatment must be consistent with the empirie and sclentific rindings and the morel values In all areas of knowledge. In this approach the offender is the center of the directed actions. He is an individual. and not merely a part of the collective, interchangeable population, mass, or crowd. Individualization, whether through group or one-to-one contact, is advanced through classifieation, diagnosis, treatment, and prognosis, by 
clinical procedures and trained personnel. Corrections also emphasizes physical structure and environmental resources.

Expressing his philosophy of corrections, John D. Case, Warden, Bucks County Prison, Doylestown, Pennsy 1venia, states:

"We are in the salvage business, not the junk business. Individuals are confined to institutions as punishment and not for punishment. Each person is treated AS AN INDIVIDUAL. Our aim is to assist in solving his problem so that he can return to the society as a law-abiding cltizen." (2)

Case continues:

"Corrections involves the use of every phase of the science of Human Engineering. It must be just, humane, and sclentific, not only for ordinary human decency, but 21so for our own safety and security. It is essential to make soclety understend that true protection--lasting protection-can result only through changing attitudes, especialiy since 97 out of every 100 persons sentenced to penal institutions are actually released to go back to the community." (3)

Although the American society has not yet devised a perfect system for treating the offender and satisfying the public, yet, it can boast of several progressive changes and advancements since the transplanting of the house of corrections and the work house to America by the first calonists. The present level of development in the correctional rield is not without precedent. A survey of the historied development is pertinent to this project. 
The earliest recognized reformation in the historlcal development of penology was the workhouse established in 1771 in thent, Belgium, by Jacques V1la1n, later known as the "father of penttentiary science". Vilain developed a classifleation system in which felons were segregated from vagrents and misdemeanants, and sexes separated. He encouraged sentences longer then one year because shorter sentences would not afford surficient time to teach a trode or to instill "good habits".

Another concept of early penal reform was borrowed from the church. It was the concept of solstude and explaw t1on, both of wich were thought necessary at that time for complete regeneration. Thus, in the elghteenth century, solitude, silence, hard work, classiflcation of types and possible instruction in religion substituted for the brutal punishment of prisoners of en earlier day.

John Howard $(1726-1790)$ was an early Engl1.sh pengl reformer whose work, State of Prisons (1777) planted the seed of prison reform in England. He proposed an insti. tution he celled a pententiary which would encourege pentitence, education, productive work, and separation by Individual cell. He and others with a deep concern for penel reform, lncluding nembers of the Soclety of Friends, were instrumental in securing passage by Parliament of the Pententiary Act of 1779 .

Penal reform spread from Europe to the American 
colonies. Prior to the American Revolution, penal laws ins the colonles fexcept Pennsylvania and West Jersey which were Influenced by the Quakers) were barbarlc.

In describing the conditions of Colonial America, Tyler strates:

"Punishment was almost exclusively corporal--the death penelty for serious crimes and some form of publicly inflicted pain or humiliation for minor offenses. Whipping, mutilation, confinement in stocks: 'ducking ${ }^{\circ}$, and branding were the lesser punishments usually provided in the sentences of colonial courts. Puritanism and Quaker ascetlcism alike condemined every form of sensualitoy, and blesphemy and implety were regarded as crimes against the state. Gambling, dronkenmess, dueling, lytme. breaking the peace, and conspicuous idieness were considered offenses meriting severe punishment, and the "common scold" was publicly ducked in an attempt to rold the community of the muisance of her virulence. Local codes meticulously prescribed the number of lashes or the number of hours in the stocks to be imposed for some ininor offenses and for others fixed the spot on the offender ${ }^{\prime} \mathrm{s}$ body where a designated letter should be burned." (4)

Because of the jnmediacy with which punishment was administered, the need for prisons in colonial America was minima I. The jail for temporary detention was all that was necessary. The rights, respect, and well-belng of Incarcerated offenders were of little concern to the public. Howevers, when imprisonment succeeded corporal punishment, fails became the first prisons and it was necessary to make thern somewhat permanent abodes. With the freedom given by the new constitution, 
socletles were organized to inspect, investigate, make reports and work to alleviate conditions in public jalls. one of these early societies. The Philadelphia Society for Alleviating the Hiseries of Public Prisons, had a twofold purpose: 1mproving conditions in Phlladelphia Walnut Street and High Street jalls, and formulating plans for a modern prison to be constructed by the state. These reforms secured legislation which resulted in the Act of April 5 , 1790 creating the prototype of the penitentiary. This act emphasized solitary confinement for certaln types of prisoners, hard and productive work, classification, santation, discipline, and religious instruction as essential to reform measures.

During the first quarter of the 19th century, furother prison reforms, which grew out of the renewed revivalism and humatarianism, resulted in two rival systems. The first of these systems was the Auburn Penitentiary (1816) in the state of New Zork. It was orlginaliy designed for the old congregate system, but reformers secured legislation for instituting the cell system. During the day, the inmates worked, worshipped and ate in a common setting, and returned to their cells in the evening. Discipline was severe. The prisoners who were marched to work in lock step, were denied face to face contact, were strictly forbidden to speak. Every infraction of the rules was instantly punished usualiy by Plogging. 
The second rival system was the Eastern State Penitentlary at Cherry H111. Pennsylvania. In this system, each inmate was provided a cell and adjoining courtyard. All activities were carried out in the cell except exercise which was done in the courtyard. The immate recelved no visitors. His only contact was with prison personnel, a nember of a charity organization and a chaplain. Communication with other inmates and the outside world was completely severed. In this type of confinement, the inmate supposedly had time to meditate, read h1s Bible, and to develop mental and splritual strength that would transform his $11 f e$ and prepare him to return to society.

Throughout most of the nineteenth century these two systems, along with those patterned after them, generated a great deal of controversy. The literature produced during this period, pro and con, is interesting. Some adminlstrative policies and several outstanding penal administrators emerged from this era.

In 1870, a group of penitentiary administrators who felt the need for penal reform met in Cincinnati, Ohio, to scudy and discuss the merits of the Ir1sh System of prison discipline. The Irlsh system of disc1pine emphasized the indeterminate sentence and the active involvement of the prisoner through work for his early release.) Th1s meeting was the inauguration of what is lonown today as the Anerican Correctional Association. Among the earis 
Pounders were Enoch C. Wines, FrankIin B. Sanborn, Zebulon Brockway, and Gaylord Hubbell.

EImira Reformatory (1876) in New York State reflected the progressiveness of the Cincinnati reformers. A substitute for the penitentiary, Elmira was established for first offenders between the ages of sixteen and thirty. Its program under the leadership of Zebulon Brockway, stressed education, athletics, military, vocational and religious training, and indeterminate sentence.

The federal government became actively involved in prison reforms when in 1891 congressional action created three Federal penitentiaries at Fort Leavenworth; Kansas, Atlanta, Georgla, and MeNe1I Island in the Puget Sound, Washington. In 1925 the Federa 1 Reformatory for Women was opened at Alderson, West Virginia, and a reformatory for young adults at Chilicothe, Ohio.

During the Hoover Administration, the United States Federal Bureau of Prisons was established. A progressive system for classification of Federal prisoners was developed and extensive bullding programs were undertaken. Advanced ideas in penology were incorporated into the Federal system. The twentieth century ushered in a new ero in penology--the classification-clinic period, sometimes referred to as the era of The New Penology. According to this new method, prisoners are sent to prisons for treatment and not for punishment. Prisoners are classifled according to 
diagrosis and sent to the appropriate institutions that more nearly meet their needs.

Today, several technjques and approaches are used in penal institutions across the United States. Among these are probation, parole, Indeterminate sentence, individual therapy, group therapy, experiments in various types of group living, education--college credits are offered in some institutions--occupational work, compet. 16ive athletic programs, and a number of other programs designed to help the released prisoner in his social adjustment.

Penal reform is by no means ended. It must be continuous and one which requires constant evaluation and analysis by each generation.

This introductory chapter has given some background and description of the alms and purpose of this exploratory research project, has revlewed origins of the study, has defined the basic terms used in the study, has attempted to set forth something of a rationale, and has summarlized its importance to the field.

The remaining chapters will present a survey of M.C.C.I.; a review of the literature pertinent to the areas of study; a description of the methodology as 1t developed and was used by the group Including description of the questionnalre adninistered; an analysis of the findings, information gleaned from the questionnalre, the results of 
tabulations and statistical tests; a summary of the conclusions reached by the group and a discussion of the implications for further studies. 
NOTES TO CHAPTER I

1. Robinson, Louls H., Ja11s, Care and Treatment of Mis-demeanant Prisoners in the United States, Philadelphta, the John C. Winston Co., 1944, pp. 1-2.

2. Case, John D., "Ph1losophy of Correct1ons", New York City, Amexican Journa I of Corrections, Jan.-Feb. 1965, p. 4 .

3. Io1d.

4. Tyler, Alice Felt, Preedon's Ferment, New York, Harper and Row, 1944, p. 268. 
SETIING: MULTNOMAH COUNTY AND ITS CORRECTIONAL INSTITUTION

The County of Multnomah, in the State of Oregon, continuing in the tradition of the early reformers, translated into action progressive correctional philosophy when 1t established the Pultnomah County Correctional Institution in 1961.

A description of the specific setting in which the study took place is appropriate. In order then to present a picture of H.C.C.I., some of the local antecedents from which it developed must be examined.

Multnomah County has a population of over $554 ; 000$. Portland, Its largest city, covers 74 square miles with a population of 372,676 . Of the remaining 350 square miles, approximately 100 square miles are heavily populated or industrial1zed。

In 1916 the Multnomah County Sherdf's Office Undform Patrol was formed. This organization' continues to grow with the 1ncreasing population and today provides a wide range of services under three legislated departments--Tax Departanent, Civil Department, and Police Department.

The Orfice of Sheriff

The Sheriff is elected to office on a partisan basls for a four year term. He is aided by an administrative assistant, an executive assistant, a personal secretary, an 
offlce accountant, and a business manger. Sheriff Donald E. Clark was elected Multnonah County Sheriff in November 1962. He has demonstrated interest in the social science approach to the general field of penology. The professionalization of police work is one of the Sheriff's goals. The professionalization of the police organization would imply that the officer on the job 1) must have an understanding of human behavior--1nd1vidual and group, 2) must be familiar with social problems and their et1ology in terms of anthropological, soc1olog1cal, historical, psychological, and economic ilterature, 3) must be quick in making intelligent legal decisions, 4) must be restrained in the use of firearms and physical force, 5) must be compassionate and considerate, and 6) must have the ability to communicate well.

Increased education and more efficient on-the-job training program are two avenues whereby professional status may be achieved. The Sheriff has made positive steps in these two aress. In June 1965, he presented a brief to the Multnom County Civil Service Commission appealing for the upgrading of educational requirements for law enforcement officers from the present two year college minimum to a Bachelor ${ }^{\circ} 3$ degree. (1) This recommendation became one of the requirements for personnel some months later.

Sheriff Clark ${ }^{\circ}$ philosophy in regard to on-the-job training is expressed in the MuItnomah County Sheroff's 
Offlee Manuel.

"Sheriff Clark's emphesis on training has further resulted in motivating large numbers of officers to pursue academic courses at the college level and to enroll in law school. This schooling is accomplished by individuals in their off-duty hours.

"The department has actively sought and sponsored nationally known schools in Multnomah County and has presented departmental schools in areas of need and competence. These activities draw students from police agencies both within and outside the state of Oregon and require the Personnel and Training officer to coordinate, gulde, and control every aspect of their presentation." (2)

Because the focus of this study is in the area of corrections, we shall look in greater detall at the runction of the Pollce Department. This department is broken down into three divisions, namely, Administrative, Operational, and Services. These divisions are supervised by veteran police captalns who are designated Deputy Chlefs.

The Service Division has particular significance for this study, for it is in this division"s portfolio that M.C.C.I. Fills. This Division is headed by a Deputy Chlef and Includes three sections: Jails, Records and Identification, and Scientific Investigation. The focus of the study is limited to the fixst section--Ja1ls.

There are three separate organizations which are supervised by the Multnomah County Sherlff. These are Rocky Butte Ja11, the Court House Ja11, and the Correctional Institution. A Brief description of the first two 1nsticutions will be given and more detalled description of the 
Correctional Institution because of 1 ts relatedness to this study.

Rocky Butte Ja11

Located at 9755 North East Hancock Drive, on the outsiclets of the eastern edge of the city of Portland, is Rocky Butte Ja11. This bastille of maximum security is situated on the site of an old abandoned gravel pit which once provided work for the inmates. Th1s location is off the beaten track, inconvenient to the public and difricuit to find for persons unfamiliar with the area.

Originaly constructed in 1941 with Pederal W.P.A. funds, Rocky Butte Ja11 was expanded in 1946 by funds rrom the treasury of Wultnomah County. This jail hes a maximum capacity of four-hundred prisoners.

The average daily population is about three-hundred men and fifteen woinen. All Federal prisoners as well as those sentenced by the county and in some instances prison exs sentenced by the City of Portland are held in this jail. Prisoners from other Oregon cities and counties and the Federal protsoners are held upon orders of the respective courts at $\$ 2.00$ per day. About seventy-f1ve prisoners housed at the location are awaiting trial on felony charges. Other felons housed at Rocky Butte are those whose cases are being appealed or who are wating transier to the oregon State Pentrentiary or Pederal. Penitentiary. (3) 
Rocky Butte is a maximum security ja11. Generally it does not permit segregation of sentenced and non-sentenced prisoners, nor does it provide separate accomodations for varying types of offenders, or men of varying age groups. Prisoners are not kept in private cells, but in large dormitory-cells, commonly referred to as "tanks". Only few of the prisoners are segregated, and then primarily for morals charges. The most perverted of these cases are sometimes isolated in the Court House Ja1l. Because Rocky Butte is so far removed from the Court House, men have to be shuttled back and forth for court appearance, consultation w1th attorneys and the like.

Court House Ja11

The Court House Jail is located on the seventh and eighth floors of the Multnomah County Court House, Portland, Oregon and is supervised by one lleutenant in charge of nine deputies. This jail is essentially a holding facility for persons who are undergoing trial, being arralgned, or having prolonged appointments with defense attorneys. Some persons booked by the U. S. Immigration Service are held at this location until further disposition.

MuItnomah County Correctional Institution (M.C.C.I.)

Multnomah County Correctional Institution, a minimum security 1nstitution, is Gultnomah County's latest effort 
to rehablitate and restore to productive citizenry those men temporarily committed to its care. Adjacent to this institution is Edgefield Manor, a county home for the aged, and Edgefield Lodge, an Intensive, live-in treatment center for disturbed children.

Concelved a medium security insticution by the former Sheriff, M.C.C.I, wa opened in December 1963, as an experiment in minimum security living. This new-type jail with its honor system and minimum security facilities elicited opposition from the citizenry of the Hood viliage community. Today, opposition from residents is minimal and Ininates are permitted to use communtty recreatlonal facilities.

The physical structure is constructed from conerete blocks and steel with a wooden roof. The building is asterlsk-shaped and patterned after the spokes of wheel. The central office, originaliy a screened control area, represents the hub of the wheel with nine spoke-11ke blocks radiating from this hub. Surrounding the bullding is a high metal fence topped with barbed wire. The fence, not necessarily incongruous with the institution's philosophy, Insures a kind of desired privacy.

M.C.C.I. has a maximum capacity of 125 1nmates, urder a single bunking system. At the time of this study the Inmate population was approximately 80 . The inmate population at M.C.C.I. is drewn primarily from Rocky Butte Ja1l. 
Other counties in the state of Oregon have contractual agreements with Multnomah County for certain prisoners.

At Rocky Butte Ja1l, an Inmate desiring a transfer to 毁,C.C.I. completes an application blank, No one is denied the privilege of applying for a transfer because of prior of fense, age, race, or present offense. However, certain somcalled psychopathic and sociopathic personalities are not consldered. If the inmate-applicant responds favorably to the screening process, he is classified as a minimum security risk and transferred to M.C.C.I.

The philosophy of the institution is directed toward providing the inmate with guided opportunity to accept and make decisions governing his own conduct and general welfare. The environment affords freedom of movement with opportunities for guidance and counselling. It is assumed that dynamics of group interaction and community living complement the individual-oriented program. In this rehab1litative center an attempt is made to approximate some of the normal activities of the free society.

Personne 1: The staff at M.C.C.I. consists of one Lleutenant, one Sergeant, one part-time Ja11 Counsellor (Psychologist), one Ja1l Steward (or cook), eight Deputies, and a part-time Ja1l Chaplain sponsored by the Portland Counsel of Churches. The personnel, as vell as the Inwates, must carry their share of the responsibility if animum security institution is to be successful. In sense, the 
offlcers at M.C.C.I. are "hand plcked" for their tolerance, understanding, and capacity to recognize and solve some of the problems which occur within the institution. These men perform multiple role. At Rocky Butte, the guard is "the bull", and is often feared. At M.C.C.I. the officer, a supportive, non-punitive person, may be seen as friend who is ready to be of service. The officer who has spent many years in maximum security situations and transferred to a minimum security situation could feel threatened and find adjustment difficult. It is for such reasons that jall personnel for M.C.C.I. are carefully selected from the ranks of Multnomah County police.

Work Program: Work has always been an Integra 1 part of man's existence: Today, it 18 strongly emphasized In twentieth century American society. Early penal reformers emphasized the value of work in the rehabilitative program of prisoners. Work seems to have these values:

1) It is a part of the therapeutic process and helps in the restoration of the man to society.

2) It develops skilis, good work habits and stimulates an on-going interest in some type of trade.

3) The remineration from work enables the irmate to partially meet post release needs.

4) It is an experience with religious and moral over-tones.

At M.C.C.I. work is high on the priority 11st. The 
Inmate recelves $25 \%$ per day worked whlch is deposited to his account. Because of lack of facilities and equipment, the work program is limited. The present progran includes anima I husbandry, farn work, butchering and meat processings service-type jobs in the county home, general malntenance at Precinct \#I of the MuItnomah County Sheriff's office. semi-clerical jobs in the institution itself, maintenance and repalr of the bullalngs, work in the laundry, print shop, Kitchen, and barber shop. The men state preferences regarding work asslgnments and these are used as guides in appointments to specific jobs. Although these preferences are considered, the counselior has the finol decision in appointment. The effectiveness of the work-program in preparing inmates for work upon release is not known. Summary of Institutional Life: Upon entering H.C.C.I。 for the first time, the inmate is given an Inmate Hanual to acquaint him whth some of the basle rules, regulations, and principles of operation. This booklet provides information pertinent to the Institution ${ }^{\circ} \mathrm{s}$ expectations of $\mathrm{him}$. (We should mention here that this Inmate ranual is not the same as the "Information Handbook" which the visitor to N.C.C.I. recelves. The former is the prisoner ${ }^{\circ} \mathrm{s}$ guide to institution al I1fe and the latter is a visitor ${ }^{\circ} s$ guide to the institution. The infomation pithin these booklets, of necesgi. ty, would be different.)

Probably the first impact of institutional Iivings 
especially for the first-timer, is the "vestment ceremony". The Inmate is divested of clothing except for his undershorts and given a clothing issue for which he is held responsible throughout his incarceration. The replacement cost of lost or damaged clothing (except for normal wear) must be met by the inmate from his jail earnings.

A part of the "vestment ceremony" is the temporary withholding of personal property. Among these items are wallets, pocket or wrist watches, rings, cigarette lighters, keys, or any other article of value. These articles are kept in sare-keeping and returned to the inmate upon his release.

Dormitory Regulations: Each inmate 1s assigned to a bunk in one of the four living areas. One of the considerations for assigning beds is work-assignment. In each unit, the bed numbered "one" w1ll be assigned to the dorin trustee. There are specific regulations pertinent to the making of beds ("milltary style"), changling of sheets, pillow cases, mattress covers, and blankets. Each man is responsible for keeping his section or space of the dorm1tory neat and clean.

Inmates are free to relax in their bunks during their Sree time; however, smoking in bed is strictly prohlbited. The men are encouraged to show consideration for the feelings and rights of others at all times.

Personal Hyglene: The following instructions on 
pexsonal hyglene are quoted directly from the Inmate

"...Wherever men live together in close groups, personal cleanilness is important. Excellent facllities are provided for your personal cleanliness and it is expected that you w111 use them" "Reference has already been made to tollet and shower facilities.) "You should shower and shave every day, more of ten if you are assigned to a work crew where you might pick up offensive odors. Electric razors are avaliable for everyone's use in the Shower Room. Since these are expensive items, we natura $11 y$ caution you to take good care of them. Make use of foot baths for this w1ll keep fungus infections (athlete's foot, etc.) under control. espectally during the summer time weather.

"You are expected to get a halr-cut at least every two (2) weeks. The Barber w111 post a schedule for halrcuts and you should check these regularly to make sure you do not miss your date. In the event you are going to receive a special visit, appear in court, or are to be released, see the Barber and he w111 make special allowances for you. Bear In mind that the Barber has been instructed not to allow extreme hair styles. You can help him to do his job by asking for one of the various conventional halr-cut styles." (5)

Mea 1s: A genuine attempt is being made by the administration of M.C.C.I. to make the food program an 1ntegral part of the rehobilitation process. Meticulous planning and care go into the preparation of each meal by the Ja1I Steward. H1s staff members are chosen from the inmate population and are often experienced cooks. The cher"s planning provides such varlety in meals that dinners are served for one month without repeating a menu. The dining room is furnished with wooden tables and metal chalrs. One table can accommodate s1x men; there are 
no special seating arrangements and the men are free to sit wherever they w1sh.

Three meals are served dally, and the serving is "cafeterie" style. After picking up knives, forks and spoons, the men are served on compartmented metal tray. Beverages are provided at each table in tin cups. Each man 1s responsible for returning his tray and utensils to the designated area. W1th the exception of desserts and meats, surflcient food is prepared so that each person may have additional portions.

The men are given a five minute call before the actual serving time. This provides enough time for them to be in thelr respective dorms where a count is taken. The men are then signaled to form queve according to dorms, with priority on a rotating basis. Enough time is provided for relaxed eating. Coffee breaks are provided dally in the recreation area.

Pedical Service: H.C.C.I. does not have a residential medical care facllity, nor personnel. Hospital personnel and doctors from Rocky Butte make regular weekly scheduled visits. At this time "sick I1ne" is held and medication dispensed. Cases of serlous 11lness are taken to the Multnomah County Hospital where medical care is provided. In the event of an emergency, doctor can be arranged for through the neighboring county home. Recreationa 1 Program: The recreational activities 
at M.C.C.I. are an Integral part of the 1nstitution's program. Activities are geared to cover a wide range of interests from indoor table games to outdoor athietic competitive sports. Currently, M.C.C.I. Is a member of a reglonal sports league and competes in basketball and baseball. This league is made up of community groups and M.C.C.I. Is the only jall group that paricipates. Most games are played away from "home". The team travels in a bus under the supervision of the Recreational Officer, who wears civilian clothes. The team members play in regular sports unfforms. The team functions under an honor system and responds to the benefits and urgings of peer pressure by conducting themselves in a responsible way. Sports compet1tion and the winning of several trophles have con-m tributed to the morale of the inmates.

Television viewing is part of the recreational prow gram. The television is located in a central viewing area. Those whing to view mat take a chair from the dining hali to this central area and should return the chair upon leaving. The program viewed is determined by majority yote. The attending officer, however, has the last word in case of a deadlock or unxesolved controversy. Sports programs are given priority by the inmstes.

Ilbrary service is not a new part of the correctlonal institutions. "We do not know just when the first prison library ras inst1tuted, but the Philadelphia Prison Society 
furnished books to prisoners in the renovated Walnut Street Ja11 in 1790." (6) The Iibrary at M.C.C.I. houses a wide selection of books, reference material, magazines, and other periodicals and is open to the men during their "waking" hours.

Religlous Services: M.C.C.I. has a chaplain sponsored by the Portland Council of Churches who provides services for three half-days a week. The Chaplain devotes one hale-day per week to group therapy and one half-day to a study and lecture type treatment usually on subjects of personal problems. Individual counselling sessions are offexed. Counseling by clexgymen is not limited to religious problems. Priests and ministers from the communty provide religlous services each Sunday. The Protestant Staff Chaplain is coordinator of all religious activities. Chapel services are held in an appropriately styled section of the bullding.

Counsel2ing Services: Counseling service is provided to some degree by all members of the staff. However, this job is the primary responsibility of the Jall Coursellor. Counselling is done on an individual basis when the inmate expresses a destre for such help. The Ja1l Counsellor and the Chaplain also offer group therapy sessions。

V1sits and Correspondence: intaining and strengthening relationships with members of his family and former 
frlends is germane to a healthy personality. Through personal correspondence and the reception of visitors the inwate can keep his famlly and friends informed of his accomplishments and of the efforts he is making to prepare himself for a successful return to the community. Members of the family and friends can and do advise, assist, plan, and encourage the inmates in these efforts. Such contacts have proven beneficial to the men who have regular visitors. Visits are held in open arrangement with various Inmates and guests forming casual groupings about the room. Staff personnel are present during visiting hours.

Sunday afternoons from 1:00 p.m. - 4:00 pom。, are designeted for regular visiting. In addition, inmetes may recelve visitors on national holidays, namely, New Year ${ }^{\text {is }}$ Day, Memorlal Day, July 4, Labor Day, Thanksgiving, and Christmas. During the three houx visiting period, an inmate may not have more than four adult visitors. If at all possible, visitors are requested to make previous arrangements 1 th the institution pertinent to the1r visit. The administration has the right to terminate any visit due to overerowding or improper conduct. Visiting is conducted in the chapel, dining and recreation areas of the building. Inmates are not limited to the number of letters they may wite or recelve. However, no outgoing letter may contain more than two sheets of paper wh th witing or one side only. All letters, with the exception of letters 
to an attorney, the court, or the Sheriff, may be censored. Stationery is provided but the inmate is responsible for his own postage.

Contents of incoming mail are limited to the letters, funds to be deposited in an inmate ${ }^{\prime} \mathrm{s}$ account, and photographs within good taste.

Commissary: M.C.C.I. provides for the basic necessities of food and clothing for the inmate. In order to meet other miscellaneous needs there is an inmate comm1ssary. The commissary is opened from 1:00 pom. unt11 4:00 p.m. and again from 7:00 p.m. unt11 8:00 p.m., and carries such items as cigarettes, candy, tollet articles, soft drinks, pens, pencils, underclothes and handkerchiefs. An inmate does not use cash to make payments; instead, he draws against his deposited funds. The Inmate who does not have a deposit fund is unable to purchase because he lis not allowed to draw gainst his work money. V1sitors may use cash in making a purchase from the store. Profits frow the operation of the commissary are deposited in the Inmate Welfare Fund which heavily subsidizes recreational activities, Use of Telephone: In cases of extreme emergency an inmate my be permitted access to and use of the institutional telephone. Permission must first be obtalned from the counsellor, chaplatn, or ranking officer in charge before any calls may be made. The inmate must first disclose the nature of the call and give information regarding the 
reciplent. If permission is granted the cal1 will be made In the offlce of the staff member who granted permission. Under no cireumstances w111 inmates be permitted to accept incoming calls.

Activities: Original plans provided for evening self-improvement programs for the men requesting them. The projected programs would include Alcoholles Anonymous group counselling, educational courses, public speaktng, and other areas of interest indicated by the men. To date however, the only program that is in operation 1 s the educational one. Individual tutoring is being proviaed by a co-ed group of college students from one of the Rorkland Colleges. The delly schedule of M.C.C.I. 1s as follons:
$6: 15 \mathrm{a} \cdot \mathrm{m}$.
Wake up
$6: 15--6: 45$
Dress, shave, make beds, clean living area
$6: 45--7: 30$
Breakfast
$7: 30$
Parm Work CaII
8:00
Arrival at ass $1 \mathrm{gmed}$ place of tork
$8: 00--11: 15$
Works
$1.1: 30 m-12: 30 \mathrm{p}, \mathrm{m}$.
Lunen
$12: 30=4: 30$
Aftemoon work
$4: 45-5: 30$
Supper
$5: 30-11: 05$
Free time for lelsure activities

The bove delly the schedule is obseryed by those shmotos on regular work crews. Others who are assigneo 
specific tasks which require varying hours do not conform to that schedule. Special dormitory and eating arrangements are made for these men. Depending on the work assignment, an Inmate may work IIve, six, or seven days a week.

Summary

This chapter gave a brief account of Multnomah County and 1ts correctional institutions. A cursory survey of the geography, political subdivision and demography was presented. Attention was Biven to the Multnoma County Sheriff's Department w1th particular emphasis

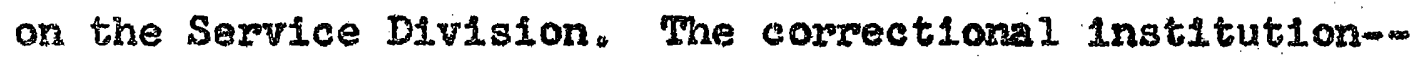
M.C.C.I.g the major focus of this chapter, was given a more detailed description. 
NOTES TO CHAPTEA II

1. Clark, Donald E., Jetter to Multnomah County Civ1l Service Commission, Portland, Oregon, June 7, 1965.

2. Sheriff ${ }^{\circ} \mathrm{s}$ Staif, Purpose, Organization, Departments, Multnomah County Sheriff's Orlice, Portiand, cregon, January 15, 1965, p. 4 .

3. Ibld.

4. Iold.

5. Sheriff's Stafe, Inmate Manual, M.C.C.I. County of Nultnomah, Portisnd, Oregon, December 1, 1963, pp. 4-5.

6. Barnes, Harry, and Teeters, Hegley, New Horlzons in Criminology, 3rd edition, New Jersey, Englewood Cilfirs, Prentice-Kal1, Inc., 1959, D. 346. 
CHAPTER III

\section{SEARCH OF IITERATURE: HISTORX CR JAILS}

The review of the 11 terature will be divided into two major categories: (1) the historical role, and (2) the current role of the jail.

From the fiction of Victor Hugo with its emotional appeal to the conscience of mankind to the prison descriptions of John Howard and his far-felt reforms, we find the recommendations of theorists out of step with the attitudes of society on how to treat the man confined to 1911. The biographers of John Howard ${ }^{\circ} \mathrm{s}$ studies sum up the unsteady progress in soelety's attitude toward the misdemeanant:
"Slow progress since that time has taken us far beyond Howard's imagination, to a system in which there is a distinctly therapeutic element; a system in which some "gaolers' are beglnning to regard themselves not as impassive watch dogs who must bring immediate punishment upon the prisoner who deviates slightly from the rules, but as understanding soc1s 1 workers Wth thom inmates can discuss their prob- lems and ask for sympthetlc guldance, a system in which all prison staffs are encouraged to develop this attitude." (I)

Criteria for Search of Ilterature

The originel assignment within the group for review of the 1iterature was divided into the following categories:

Fsychological Absiracts

Soc10logical Journals

Soc1a1. Work Journa is 
Textrooks on Criminology, Sociology, and Penology Abstracts of Theses

In addition the group was expected Individualiy to be alert to other information gleaned from footnotes and references which would be pertinent to the study, with particular focus on jails and correctional institutions, the treatment of misdemeanants, and implications for the practice of social work. Generally, the search was to be limited to the period from 1960 to 1965 . The search of I1terature did not cover the institutions for long-term offenders. However, any attempt to present the practice of social work in jalls and correctional institutions must include the classic l1.terature on criminology written in the period of developing social consclousness and evolvement of social institutions to meet these problems, for full understanding.

Evolution of Criminal Iaw

Four distinct stages exist in the evolution of criminal law: (1) Vengeance, or retribution, (2) Repression, (3) Rehabilitation, and (4) Prevention. (2) Ceorge Bernard Shaw describes the three offlclal objects of our prison system as vengeance, deterrence, and reformation, with the only one achieved belng vengeance. (3) Ell1ott, discusses five categories in her detalled analysis of the motives of punishment: (1) Retribution or vengeance, Deterrence, (3) Reformation; (4) Reparation, (5) Social 
utility. (4)

Soclal utility is a broad classification and may include all except retribution. She excludes the aspiration motive of atonement for offenses through suffering. the suffering meted out in proportion to the gravity of the crime. "In a very real sense this concept is nothing but vengeance or retribution in the name of moral law".

Vengeance has roots in the earliest known c1v111zations and is popularly referred to as "lex talionis"-the law of retallation or, "an eye for an eye" and "death for a death" principle of the Mosalc Code. (6) A present day example is the death penalty for murder.

The deterrence motive is to instill fear of the law In the mind of the offender and to prevent the breaking of the law by examples of what happens to those who break the 12\%.

The reformatory motive is concerned with the rehab111tation of the offender in order to bring about his satisfactory ajustment within the group. The medieval church with 1ts tenets of explation, penitance, and reform contributed to punishment through reformation. The silent approach in treatment by the Quakers is an example. The reparation motive alms to force the offender to pay damages to the pergon injured.

To give an example of historlcal perspective, Hines wrote: 
"Of all the perplexing questions which confront the statesmen and the publicist, probably the most difricult of solution is that which relates to the proper treatment of crime and criminals. This is true. whether the question is approached from its theoretical or its practical side".

The writer continued, that an enlightened jurisprudence must rest upon the principle of due regard to the rights and interests of convicted criminals, as well as of the community which 1 t seeks to protect. He concluded that the treatment of crime must concern itself with repression and prevention and the treatment of criminals by extirpation or rehabilitation. This quote from V1ctor Hugo reflects the humanitarian phllosophy evolving in the eighteenth century toward social problems:
"The study of social infirmities and de- formities, with a view to their cure, is a sacred duty. The mission of the his- torlan of ldeas and of morals is not less obligatory than that of the chronicler of events. The latter skims the surface of civilization. He registers royal marriages;
the birth of princes, quarrels between kings, battles, convocations, the achieve- ments of men illustrious for their public services, political revolutions. He describes the external aspect of events. But it is a deeper and more arduous task to penetrate beneath the surface; to lay bare the foundations on which the social structure has been reared; to tell of those who labor, who suffer, and who walt--of womanhood staggering under bur- dens too heavy to be borne; of chlldhood in 1ts young agony; of the sllent secret conflicts which allenate men from their kind; of the obscure ferocities, the prejudices, the intrenched injustice, the subterranean reactions of law; of the hidden evolution of souls; of the formless shudderting of the masses of the starved, the halr-clad, the 


\begin{abstract}
disinherited, the fatheriess, the unfortunate, and the infamous; of all the hobgoblins that wander in the dark. He who would lay bare the mysterious springs of human actions must descend--with a heart full at once of charity and of severity, as a brother and as a judge-minto those impenetrable casements where crawl in confusion those who bleed and those who strike, those who weep and those who curse, those who fast and those who devour, the wronged and theis oppressors. Have these historians of the heart duties inferior to those which are la1d upon the historm lans of the world ${ }^{\theta} \mathrm{s}$ extexlor life? Hes Dante less to say than Mchiavelli? Is the under-world of civilization, because it is deeper and more gloomy, less real and important than the upper? Can we know the mountain, if we know nothing of the caverns?" 18
\end{abstract}

Origin of Ja11s

Historically the ja11 or gaol was the antecedent of the present-day prison. The ilrst function assigned to Jalls was a place to detain the accused who was awalting tria1, or the convicted who was awaiting punishment. As imprisonment became the mode of punishment replacing physical punishment, physical torture and public ridicule decreased.
"Out of the jail grew the prison. Then came the reformatory, the fuvenile school, the specialized 1nstitutions for different problem types. But the jali remains and is not vexy different from what it has always been." (9)

The jail was not equipped for long-term sentences, and has become, In modem soclety, a place to confine the short, term offender and the individuals awalting trials. 
Many writers describe the conditions in the majority of fails as deplorable, antiquated, unfit for humans, but as a soclety we have permitted these conditions to remain unchanged and unchallenged as Sutherland describes:
"An unbelievably filthy institution in which are confined men and women serving sentences for misdemeanors and crimes, and men and women not under sentence who are simply awalting trial. With few excep- tions, having no segregation of the uncon- victed from the convicted, the well from the diseased, the youngest and most $1 \mathrm{~m}$ - pressionable from the most degraded and hardened. Usually swarming with bedbugs, roaches, lice and other vermin; has an odor of disinfectant and flith which is appaling; supports in complete laleness countless thousands of able-bodied men and women, and generaliy frords ample time and opportunity to assure inmates a complete course in every kind of viclousness and crime. A melting pot in which the worst elements of the raw materials in the crim- Inal world are brought forth blended and turned out in absolute perfection." (10)

Some of these conditions are present in the Portland City. Ja11 according to recent newspaper articles in the Oregon1an. These vignettes appeared in a recent series of newspaper articles on present jall conditions in Portland:

"The fault for conditions that exist lies to a great extent on the city's insistence on keeping fecilities constructed in 19121913 to house 75 prisoners. Today, it is not unusual for 350 men and women to be housed there on some days." (11)

"There are no facilities for segregation of prisonexs.... Murderes, and thieves, perverts and homosexua 1s, drunks and boys between 18 and 21 , repeaters and first offenders, are all thrown together. 
"Often three or four prisoners must share a small cell. Many cells have no bunks. In dormitory blocks bunks are stacked four deep. One block, 30 by 40 feet, sometimes holds as many 2872 prisoners.

"There is no room to exercise, no rehabilltation program, no real counselling... not even a private place where a man can talk to his minister or his attorney....

"Foul leakage from cell tollets is a reminder of plumbing installed more than 50 years ago.

"The jail reeks of disinfectant. Cell bars and walls are thick with paint and a grim jall joke is that paint is all that holds the place together.

"Most of" the jail's Inmates have been arrested on drunk charges. Only about one in ten faces felony charges. Once arraigned, persons charged with felonies are transferred to the county's Rocky Butte Jail to await preliminary hearing in Circuit Court." (12)

"Four young men--st1ll in their teens-were housed in an overerowded cell--a jumble of bodies, heat and smelis--during a recent long veekend." (13)

In general, modern writers attribute the poor conditlons to the methods of administering ja1ls, the role of the sheriff, lack of supervision, lack of funds, polttics, and public lethargy. Federal officlals deseribe jalls as:

"a sleve through which comes the population of all other penal institutions and a goodly portion of the mental hospitals. More than one mililon persons pass through the jails of this country each year. For every one person cominited in a prison or reformatory, ten are committed to jalls. At any one time something like 50,000 inmates may be found in our jails. The jail is the first institutional experlence of 1 ts kfind for hundreds of thousends of men, women, and children." (14) 
Writers point to the poor conditions under which transgressors of locel statutes serve imprisoment. In contrast, transgressors of Federal laws in America, as well as in Europe, typically serve imprisonment under more humane conditions.

Origin of Correctional Institutions

Early English records show the development of the house of correction and the workhouse as an effort to deal with the problems of vagrancy and unemployment present in sixteenth century England. In phllosophy, these early inst1tutions were quasi-rel1ef, quasi-penal, and quasimedical. The institutions met the needs of certain groups of soclety: (1) the hordes of wandering ldle who would work if they had a chance, and (2) those who would not work unless they were compelled to do so, (3) young adults who needed special tralning in order to work, and (4) those who were in part incapacitated.

The establishment of houses of corrections and work houses was not untversal in all counties and munielpalities In England. Robinson describes the evolution of these Institutions as follows:

"Grradually, the house of correction took on the character of a place for the imprisonment of petty offenders. Finaliy, it vanished entirely from the English penological scene and the worichouse, where evidentiy the incapaciteted group gravitated, became the English almshouse." (15) 
The Industrial Revolution produced tremendous soc1al change. People were no longer attached to the land and population moblitty which had been patterned toward land acquisition now became, in addition, patterned toward job avallablilty. The change from agrarian economy to industrialization gave impetus to city development and the concurrent increase in soclal problems. Legal statutes were broadened, at times scmewhat haphazardly, in an attempt to control these problems.

In America, the eariy colonial laws were a part of our English heritage. In the colonies of Pennsylvania and New Jersey, records show provision that all prisons should be workhouses for felons, vagrants, and loose and ldle persons. (16) In theory, work and education for the misdemeanant were identifying features of both institutions. Their development has been varied and checkered in the history of care of the short-term offender. Ell1ott concludes her history on the house of correction with these remarks:

\footnotetext{
"From the beginning houses of correction were a part of the shift from corporal and capital punishment to incarceration for punishment. The offenders so punished were chiefly misdemeanants.

"These institutions 211 are far superior to most jails; they provide employment and some vocational training; but, like the jails they do very littie rehabilitative work:" (17)
} 
History Related to Project

During recent years interested groups and Individuals have contributed time, effort and money toward active experimental rehabilitation programs. Statisticians and researchers, professionals from the fields of law and saclal work, lay persons, church groups such as The Cospel Mission, the Quakers, and the John Howard Soclety have become involved in practical application of various aspects of theory. A recidivist is no longer a mere number in a tabulation at the end of the fiscal year since agencies and individuals have begun to look at the inmate in the institution with the idea that his unresolved problems accompany him as he leaves to return to the community. Is it possible for the institution to function effectively in the area of Inmate need? Robinson stated this issue succinctly long ago:

"If one were to attempt to state the relative importance of the jail in our network of penal and correctional inst1tutions, he would have to take into account other factors than those mentioned, for example, the length of time a man spends in an institution. Is an institution which keeps ten men ten years each as important as one that keeps two hundred men six months each? Another point that also would need to be considered, is the quality of the imprisonment, that is, whether the particular institution attempts to educate or train the prisoners. Thus, from a ph110sophical standpoint, the problem of deciding on what is the exact importance of the ja1l becomes extremely complicated. But the large number of these institutions plus the 
fact that they do handle an enormous number of human beings are enough to warrant $a$ careful examination of their work and of their future place in our scheme of government." (18)

A search of the 11terature developed several issues pertinent to the role the jail performs in society. What function does it play in the present treatment of the offender? How has 1 t fared in the development and advancement of social institutions in America? If the ja11 has a.role to play in modern soclety, what are the needs of the Inmate? How are the needs of the inmates to be understood In the light of the development of the behavloral sclences under the impact of soclocultural concepts? Should jails be abolished? What purpose of society do they fulf111? What has been the philosophy of soclety in punishing man? What are the roots of our present attitudes on the punishment of man by locking him up?

Are there criteria by which the success or fallure of the jail system can be measured? Are there criterla to measure the role soclal work can play in the treatment of misdemeanants?

These questions are directly related to the purpose of the project, the needs of the misdemeanant. It would appear that historically, work and employment were viewed as the principal needs of misdemeanants. Idleness of 1rmates characterized jails. The house of correction was not unfversal. A review of curpent l1terature will reflect 
present practices in meeting needs of misdemeanants. 
1. Howard, D. L., Howard, John: Prison Reformer, Archer House, Inc., Hew York, N.Y., 1963, P. 165.

2. Wines, Prederick Howard, Punishment and Reformation, Thomas $Y$. Cronwell Co., Revised Edition, New York, 1923, pp. 6-7.

3. Shaw, George Bernard, The Crime of Imprisonment, Philosophical Iolbrary, New York, 1946, pp. 76-77.

4. Elliott, Wabel A., Crime in Modern Society, Harper and Brothers, New York, 1952, pp. 445-450.

5. Ib1d., P. 446.

6. Ib1d., pp. 445-450.

7. Wines, Op. C1t., p. 1.

8. Toid., p. 3 .

9. U. S. Department of Justice, Lets Look at the Jaller's Job, Correspondence Course For Jallers; U. S. Bureau of Prisons, Wn., D.C., n.d., p. 2 .

10. Sutherland, E. H., and Cressey, Dons ld R., Pranclples of Criminology, Fifth ed., L1ppincott, New Tork, 1955. p. 365 .

11. Sanderson, W1Iliam and Olmes, Robert, "Serles of Art1cles on Portland Ja1ls", The Oregonian, (Portland, Oregon): Section III, p. 6, col. 4. through 6, November 29, 1965.

12. Op. C1t., The Sunday Oregonian Forum, p. 1, col. 3 through 6, November 28, 1965.

13. Op. C1t.. Section III, p. 16, c01. I through 8, November $30,1965$.

14. v. S. Department of Justice: 0p. C1t., p.2.

15. Robinson, Louis N., Ja11s, Care and Treatinent of Misdemeanant Prisoners in the United states, The John C. WInston Co., PhIladelphis, 1924, p.93.

16. Ib1d.

17. Ell1ott, Op. Cit., pp. 508-509.

18. Robinson, Op. Cit., p. 8. 
SEARCH OF LITERATURE: CURRENT STUDIES IN CORRECTIONS

There appears to be, in recent years, some attempt to clarify and compare the many differing theories in this field. There should be awareness of confusion concerning terminology which adds to the complextty of those attempts at comparison. Each fleld tends to develop its own vocabulary. Even within a single fleld there is wide variation and lack of unity on this aspect alone. Man, in his search for a reason for crime has answered this through the years by guess, superstition, and by scientific investigation.

Theorles of Criminology

Dressler, in his anthology, summerizes cause as follows:

"A cause is that which makes something happen. The cause of some effect refers to an invariant relationship between two phenomena." (1)

He lists an array of causes that have been advanced in the past several decades which range from "Momism" to the "Unw1lingness on the part of the government to estabIIsh a Federal Department of Morals". (2) He concurs with other writers that invariant relationships between any single fact or constellation of factors and crime and delinquency are yet to be discovered. 
Early theorists were of two schoolsm-the Classical and the Positivist. (4) Beccaria (5) and Lombroso were early Italian scholars who made extengive studies on the cause of crime. Lombroso's theory of the organic. etiology of criminal behavior continues to form a basis for some recent research by $\mathrm{E}$. A. Hooton, physical anthropologist. (7) He completed a study based on biological infer. 1ority, repeating the errors of method and interpretation committed by Lombroso. His studies are not significant in reflecting cause of criminal behavior.

Siri Naess attempts a conceptual clarification of criminal causation. He reviews a select group of sociological, psychiatric, and cross-discipline theorles. Another terminology for these theories is Social Pressure and Supermego. (9) Included in this study are: Sutherland, Herton, Sellin, Sarbin, Gough, Thoma and Znanleckt, Healy and Bronner, and Frledlander. Naess attempts to re-formulate these theories in a common language using the concepts of role prescription, role enactment, $1 d$, ego, and super-ego. He concludes that these theorles concexn pressures originating in the social surroundings of the persons and could be grouped as hered1ty and environment. Austin Turk, (10) a sociologist, points to the current emphasis upon descriptive typing of offenders in accordance to offense or psycho-soclal characteristics, with typologies reflecting the rehabliltation interest 
toward changing behavior. He contrasts this to the theoretical interest in learning how the adjective "criminal" came to be applied to the individual and his behavior.

Turk argues for recognition of differences between the reformist and the analytical interests, and the research problems of each, which are fundamental and should be made explic1t.

In the fleld of criminology, Donald Clemmer (11) studied the social organlzation of a prison. Many persons have been concerned with the effect of organization on behav10r. Donald Cressey (12) has drawn together a segment of these recent contributions. Among them is an article by Clarence Schrag, which states:

"Principles and generalizations are o1f...
then... statements asserting certain
interrelationships between criminal actions
and various conditions under which these
actions may be expected to occur. If the
generalizations are sufficiently detailed
and accurate, then observations of the
specifled conditions should enable us to
predict the resulting criminal behavior.
"Control of crime 1s believed to be possible
when the variables on which prediction is
based are subject to deliberate modification.
By changing the statuses of persons or groups
with respect to the variables that are
associated with criminality, designated
changes presumably can be produced in the
amount or the nature of criminal behavior."

Schrag looks especially at Sutherland's theory of different1al association; (14) Durkheim's theory of anomie: and Weber's theory on analysis of bureaucratic 
organizations, (16) plus additional contributions made by others working in the tradition of these three. He outlines one foundation for a theory of correction based on role configuration within a framework of social relationships. These configurations are: (1) prosocial, (2) antisocial, (3) pseudosocial, and (4) asocial. (17) This is termed:

$$
\begin{aligned}
& \text { "a typological system, which attempts to } \\
& \text { formulate the emplrtcal relationships } \\
& \text { among concepts or variables by deslgnating } \\
& \text { which of the combinations are expected to } \\
& \text { occur with high frequency and which ones } \\
& \text { should occur infrequently or not at all." }
\end{aligned}
$$

He further states that although the typology may have Imperfections, it should show the relationship between criminal behavior and variables of culture, social system and self.

With recognition that criminality is not always a rational cholce between right and wrong but rather a pattern of deviancy from norms which are determined by a dominarit law-making group in soclety, there has been novement away from punishment and toward rehabilitation through treatment. Some theorlsts have focused on development of typologies and classifications of behavioral patterns as they may be used for prediction and control. One of the most recent contributors to theory on treatment is Don $C$. Aibbons, who developed a typology for juvenlle delinquents and one for aduIt criminals, to be used as a diagnostic 
system which would result in an orderly process of therapy. (19)

Treatment has traditionally been a combination of the clinical method or Individualization and the group relations method. The latter approach was a break from the treatment of the offender through isolation. Current isterature, particulariy in the coriectional publications, includes a number of studies utilizing the Individual treatment of the misdemeanant. These studies cover classiflcation, pre-parole procedures and probation studies. The literature also covers the group relations method in a number of experiments in self-government, education, grouping of simflar offenders, ways of making contacts with law-ablaing groups, halfway houses, and work-parole. The concepts of individualization and socialization of the fa11 1nmate are not new. One of the earliest AmerIcan social scientists to write on the subject of the county ja1l, Stuart Queen, says:
"In other words, individualization of offenders is only one spect of their refor- mation. The other slde of it is soclaliza- tion. These are not two distinct entities. They are simply different ways of getting at the same thing. Because man is what he 1s, we cannot have the one without the other." (20)

The lag in the implementation of the rehabilitative role of corrections, according to aibbons, (21) stems in part from the Image of offenders as "bad" persons who w11fully violate criminal laws. Another problem is 
enlisting sound financial support of correction programs, mainly because politlcians reflect constituent oplnion that the misdemeanant must not be coddled.

California is one of the states which has attempted to overcome public apathy through agressive leadership, professionally-trained staff, ambitlous programs for treatment of juveniles and aduit inmates, and evaluation of these operations through research. These approaches have become an established part of the correctional effort under the Calffornia Youth Authority and the Depertment of Corrections. (22) This state is considered a model for many others in developing progressive correctional programs.

A model of contemporary correctional institution Is described by Howard B. Gill, who outlines four basic essentials characteristic of such an institution:

1. Normalcy as it has to do with the interpersonal relationships between officlals and staff, with rules and regulations, and ith the general overail climate of the institution.

2. Small group principle as this applies to IIving quarters, dining, bathing, work program, and le1sure-time activities, including hobbles, athletics and entertainment, visiting, religious services, and medical care.

3. Inmate particlpation based on joint action and jolnt responsibility for 211 institution activities except discipline, parole, rinances and similar orfictal administrative actions.

4. Community contacts, including oringing the outside community into the prison and taking the Inmate 
to the outside community in all

reasonable ways possible, (23)

There are innumerable descriptive studies on many experimental programs being utilized in different locations. Robert $F$. Kennedy describes the success of halfway houses in reducing the incidence of parole fallure; (24) David $R$. McMilian discusses a recent program of work furlough in Orange County, California: (25) and Donald alaser writes about residential centers for community guidance and gradm usted release of convicted persons, as a development in the parole system. (26)

Another aspect of this field often found in writings Is that of prevention through early intervention. Samuel Hencher states,

"A social service is most effective and least costly when the problem it is deslgned to meet is anticipated and planned for in advance, or when the problem is dealt with as quickly as possible after it arises. Many problems are so general in nature that plans to meet them can be made well in advance. If advance planning is not done, the social intervention required later is both complex and expensive. Moreover. uniess help is offered at the point of crisis, many people cannot achleve their maximum potential and others remain either moderately or severely handicapped." (27)

Fundreds of other studies such as yearly reports by the U. S. Department of Health, Education and Welfare, including Current Projects in the Prevention, Control, and

Ireotment of Crime and Delinquency have been written. (28) These studies are contributing to substantive findings in 
the correction f1eld. Qibbons sums up this area of the Iiterature with:

"..theoretieal statements have multi-
piled faster than substantive research
findings so that the subject area is
presentiy characterized by a number of
unresolved theoretical issues for which
relevant data have not yet appeared." (29)

These studies cover a number of theories on the cause of criminal behavior as well as treatment. The study will now focus on the contributions of the profession of social work in meeting needs of individuals, including those of the misdemeanant.

Need Concepts in Social Work

The concept of needs is familiar to the profession of social work. The profession has historlcally developed around the need an Individual brings to the agency. times in the past elghty years since the Charity Organi. zation Movement and the Settlement House Movernent, the profession has implemented change in function and focus to meet need in times of crisis. The profession has been moving through a period of attempting to understand and apply theory concerned with the interaction of psychic and soctal development of individuels. The profession has developed methods in casework, groupwork, and community organizetion with a growing interest in research.

In defining needs, Erikson has descrtbed the Importance of looking at man's total mechantam: 


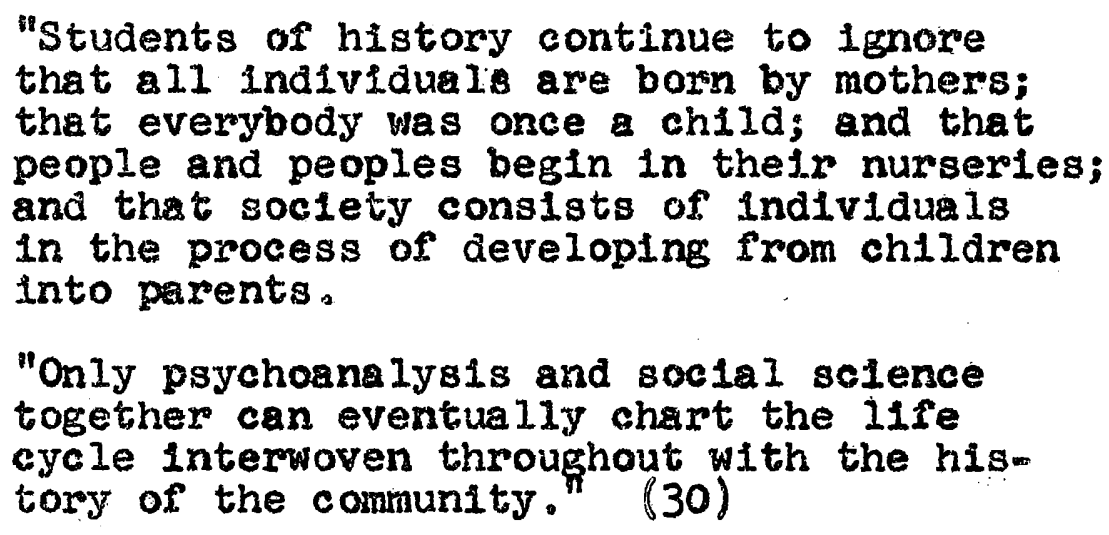

Florence Holl1s develops a frame of reference basea on Freudian influence, writing that man is influenced by Instinctual drives and needs and by environnental meeting of these needs. (31)

Erikson expanded and socialized the theorles of Freud, succeeding in bullding a bridge between psychosexual theory and social behavior. The concept of suparego is described by Erikson as:
"The superego is the internalization of all the restrictions to which the ego must bou. It is forced upon the child by the critical influence of the parents. and later, by that of professional edum cation, and of what to the early Freud was a vague multitude of fellow men making up the "milleu" and "public oplnton"." (32)
Leighton describes the development of personality, with a psychosoctal orientation. The "self" is a complex of indivioual characteristics, including hereditary phy sique, plus values, attitudes, and needs which are incorporated through interaction with influential others, and further molded through significantly important enviromental and group memberships. 
"Correlatively, it is the unique human
capacity for separating self from other,
for distinguishing the ego from an ob-
jective physical and social world out
there" that makes it possible for us to
concelve and elaborate soclal patterns.
Self and society, although distinct, are
interdependent, and each depends for 1ts
existence on the existence of the other."

Soc1al work literature has shown an accumulation of theortes on which to base the needs of individuals. Most writers pointed out that further experiments and research should be made in the application of these theories. In the corrections fleld there is pauclty of material on the needs of short-term offenders.

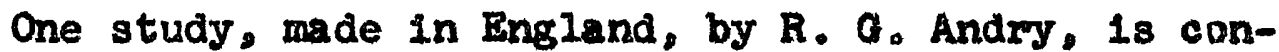
cermed with this type of offender. Sentencing procedure and post-release needs were examined. Recommendation was made for a "Reconstruction Centre" which would develop a program around occupationa therapy, facilities for vocational training, and group activities. The work which the offender would learn would have to be satisfying and rewarding in order to have a permanent changing effect on behavior patterns, goals and attitudes. Teamwork aiso was considered essential in order to develop a pattern of work Ing with rather than gainst other persons. Punlshment was handled through fines of sufficlent size to be impressive and could be paid by instaliments over a period of time, partially as restitution to the person agalnst whom the offense was committed. The needs as outlined seemed 
bastcally within categories of psychosocial and employment or training. (34)

Continuing search of ilterature in this area, Harvey Treger suggests that needs of the offender are recognition of his law violation behavior; motivation to change; developling Judgment; self-understinding; a feeling of being worthwhlle, and a purpose and direction in 11fe. (35) These suggested needs would fit basic needs of people everywhere.

Eugene Helmler, an Inglish psychtatric social worker, differentiates humen needs, termed "satisfactions". between the primary level of relationshlps during infancy and ch1ldhood and the adult level. The primaxy needs are the same as adult needs but focused inwardly toward self and family.

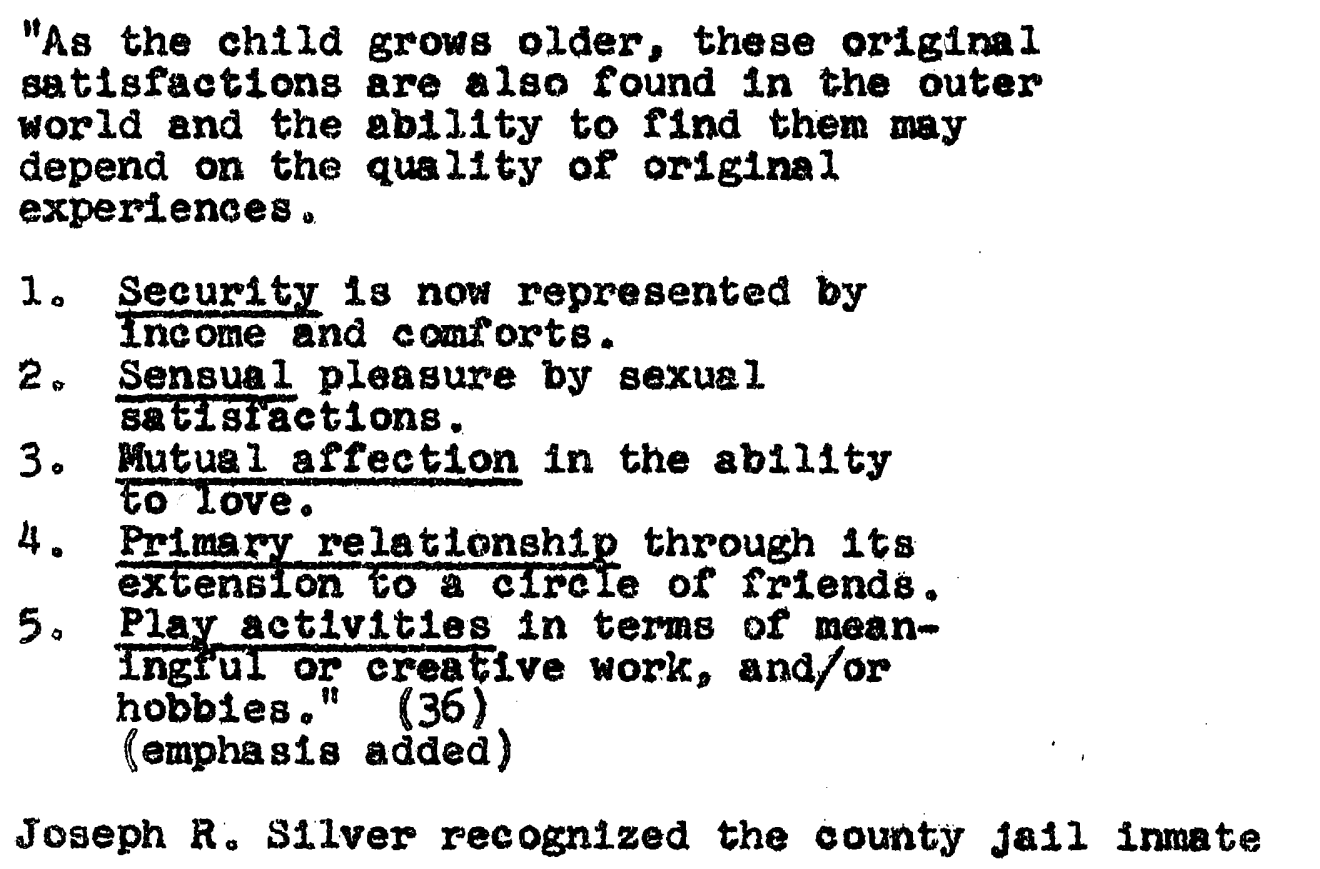
as having many complex problems, including patterns of 
emotions l disturbance, with too much rejection in childhood and at an adult level, or, in contrast, too much permissiveness:

"Many of the very obvious problems of this group have to do w1th concrete needs. Merely meeting these concrete needs without getting into the deeper material of the personal adjustment means losing a chance---perhaps the only chance-to really help the individual. Skilirul helpful intervention at such a time of crisis may be what is required to break a continuing pattern of delinquency."

A center has been operating in Oakland, California, since August, 1965, directed toward meeting the needs of released prisoners. In a letter to a project member, it was stated:
"From the staff point of view we cee certain
'lacks" in many men which we might interpret to be needs if the men are to develop as we would have ther develop. Such 'needs. are ror (I) constructive iniendships, (2) constructive lelsure time interests. (3) more farsighted goals and (4) employment skilis. When we look closer at the latter "need" for employment sikilis we can see frequent lack of preparacion for work, limited ablilty to find work and impolred ability to hold a job.
"Some of these staff-observed needs may be felt by some of the paroled men, but 1t appears that the felt needs of the majority must be expressed in more ele- mental terms. In summary there seem to be (1) assurance of basic physical needs, (2) affection or acceptance by others, (3) alleviation of fear or boredom and (4) pleasure giving activities." (38)

Special Areas of Need

Family relationships are a primary concern in the 
developmental pattern of an individual. Literature review revea ls many recent studies have been constructed around the concept of the family as an institution. There is a certain universality to basic individual needs. A Californta study focused on women prisoners and their famtlies. Looking at the family as an institution "with Interacting role functions which include emotions I functions". (39) separation of any one member from the group results in change for all group members. The role function of the mother probably is of greater Importance than the role function of the father. This, however, depends on the age level of the children:

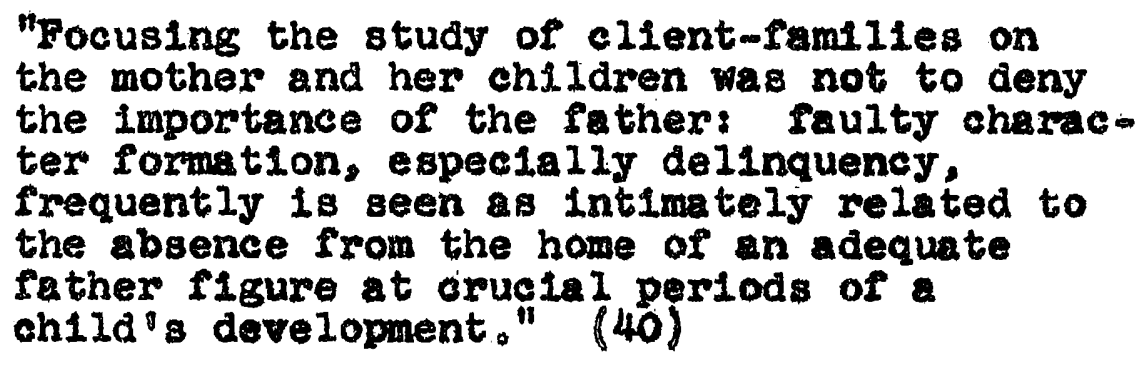

However, there are consequences to be reckoned with in regard to self-1mage and persons 1 1dentity for each family nember. In addition:

"Whenever parental separation and famlly spintering occur, the consequences for the children are determined by many factors, including who $1 t$ is that has been lost to the other family members, the number lost (1.e., extent of splintering), the prior cohesiveness and functional effectiveness of the family, the ages of those involved, the reason for the separation, the duration of the separation, the substitute situation, etc. The sequelae of separations be described in terms of economic, phystealblological, erotional, and social factors. 
While these factors are interdependent and, in reality, do not operate separately, they nevertheless provide a convenient means by which the effects of family separations might be described." (4I)

Sldney Friedman and T. Conway Esselstyn, in another California project, studied the effect on children whose father's were ja11ed. They contend that most absences of the father from the home (11lness, milltary service, divorce, eto.) are for reasons which are socially accepted and therefore not applicable to the study, since a jail sentence carried with 1 social disapproval. The approach was through public school teachers using the "University of Pennsylvania Pup11 Adjustment Inventory, Short Form", to measure differences between an experimental group and two control groups matched as to age range and grade level. Similarity of socioeconomic level was not considered a fector as the chlldxen studied were from fairly uniform areas in this respect.

In sumary it is show that jaling the father results in a negative response on the part of children as related to school and other areas of adjustment. Girls are affected more adversely than boys. It is suggested that:

"Vital and continuous cooperation and coordination is required between correctionel, welfare and educational agencles. Provision for special attention to children at the time of their fathers" confinement should be part of general soclal service practlce everywhere. It should not be left to chance or the unusuel incident." (42) 
Another area covered in the review of literature was the alcoholic offender. Classification systems of fail inmates include a high incidence of the drunkard or alcoholic. (43) What js the present opinion of experts on effects of jail confinement for the alcoholle? Some of the opinions, according to current research 11terature are: ja1l does not reform the alcohollc; ja1l does nothing besides affording a temporaxy service to the communtty; jall further degrades the alcoholic inmete and confirms him in his dependency.

One study of chronic drunkenness in Canada suggests that the lot of the chronic drunicenness offender is not as hard as many surmise and that the jall may meet needs of the inmate other than punishment. It points to the "meager affective relationships" (44) of the chronic drunk on the outgide and suggests that jall may meet needs of stable environment, a substitute social system, and a quasi-familial setting. The distinction is made between the overt alcoholic and the hidden aleoholle, clting the need of correctional officers to study the fall as a resoclalizing agency in how to best meet the needs of both types. (45) Other studies are pointing to the medical needs of the drunken offender and the need to help this group bridge the gap back to the communtty. Tinsley and Hunter in an address to the American Corrections I Association, define the major areas of a pre-release guidance 
center. These areas are employment commensurate with his ab1lity, counseling with problems, Including alcoholism, family, etco, and use of community agencies such as Alcoholics Anonymous. (46)

We1l and Price described a rehabilitation program for the alcoholic in an address to the American Correctional Association in 1962 .

"Some formalized system is needed by which patients are routed to the vaxious facilities and services of the center. A multiphasic screening clinic staffed by qualified physicians (some speclal1sts in psychiatry), nurses, soc1al workers, vocational counselors, and other Q111ed professional personnel should routinely see every admission to the center to determine whether the patient should remain in the acute care unit in the center, be transferred to general hospital or mental institution, be returned in some cases to the city fail, be assigned to the center's rehabilitation, custodial, "day and night center", be handled on an outpatient besis, or sent home to be seen by the person's family physician. This screening unit is probably the "core" of the entire operation. Placing the patients in unit that does not meet their needs or one that is incompatible with the program of the center, can be expensive to the institution and can be detrimental to the patients." (47)

Role of Soclal Work

The Ilterature has shown the expanding role of social work in the correctional field which is timely and pertinent to this study.

Sochal work is defined by Jeanette Regensburg as:

"That which seeks to enhance the soctal functioning of individuals, single and in 
groups, by activities focused upon their soctal relationships which constitute the interaction between man and his environment. These activities can be grouped into three functions: restoration of Impaired capacity, provision of individual and social resources. and prevention of social dysfunction." (48)

Social casework is often differentiated from social work as being a psychosocial treetment method. Social work practice involves intervention wth the purpose of Improving, restoring, meintaining, or enhancing the social functioning, and the social role performance of individuals. (49)

Elllott Studt in her work for the Council on Social Work Education defines the role of social work in the fleld of corrections as follows:

"The present historically necessary task of the corrections field is to define the nature of rehabilitative treatment for offenders, to develop the structure for such treatment and to prepare the personnel to man such sexvices.

"Becruse social work is a discipline with a formulated body of knowledge and skills specifically concemed with the modification of the social functioning of individuals, it is one of the professions with a potential contribution to make to the professionalization of correctional service."

Her fundamental premise is that the basic structure of soclal work prectice, Including the processes of sirudy, diagnosis, evaluation, and planned work is 1nherent in the role of the social worker in the correctional system. Special knowledge and skills are required for competence In this fleld directed towards helping individusis, groups, and communties. Among the basic tasks assumed by the 
soclal worker in corrections are:

1. Preparing meaningful reports on the of fender and his unique social situation.

2. Supervising the client ${ }^{\prime} s$ social activ1ties in such a way that he can better meet controls.

3. Helping the involuntary client to use help in problem solving, particularly around the problems of stress created by law enforcement.

4. Equalizing the problem of authority for the client in accepting necessary controls as provided by the varlous social agencles, schools, enployers, parents, teachers and institutiona 1 personnel.

5. Functioning effectively in a multipledisc1pline agency, sharing and participating in decisions directed towards the ultim te adjustment of the individuel.

6. Contributing knowledge of the fleld of corrections to the community in the development of sound sociel pollcy and action. (5I)

other writers in defining the role of the social worker in corrections argue that generic social work edo ucation his not been concerned about the special problems of dealing with captive persons. However, workers with experience and education in social work have been engaged in proctice in authoritetive flelds for many years in the Juvenlie Courts, for example.

There are nany Interrelationships between corrections and social work. The Oregon Council on Crime and Delinquency has been an active supporter of the developinent 
of a school of social work in this state. The desire to utilize social work training in this fleld is evidenced in the recruitment programs of correctional institutions. Carle F. OPNe1l in describing his work with prisoners speculates that the underlying dynamics are no different from other groups of clients:

"Outstanding problems are emotional dependency, feelings of inadequacy, basic lack of trust, psychosexual confilcts, quthority problems, schizold patterns, and antisocial identifications. Motivation toward treatment varies considerably, with wide extremes. Involving a poorly mot1vated client in meaningful treatment is a primary challenge for the caseworker." (52)

Another focus of the role of social work in the fleld of corrections is follow-up care with the offender aiter discharge. Samuel Mencher in discussing accessibility as one of the primary functions of social welfare says:

"...social agencies have been continuously plagued by the falluxe of those who most need their services to take advantage of them. The present structure of services is too haphazard to meet the needs of the general population. On the one hand, the better-educated and the well-to-do Independently make maximum use of avaliable health and welfare resources. On the other hand, in spite of the efforts made by both public and voluntary agencles to provide comprehensive services, they are not fully utilized by those who have been forced by indigence or other critical conditions--such as mental and physical handicaps, crime and deilnquency, and so on--to come into contact with welfare agencles." (53)

Soclal agencles in general have been reluctant to work of th the offender for several reasons. He is highly 
resistive in entering a helping relationship and does not voluntarily seek help for his adjustment problems. In meeting the unique needs of the offender, the agencies hove been facing two problems: (1) developing skills in working with resistive clients, and (2) absorbing a new group of clients in their already understaffed programs. (54)

A recent project sponsored by the office of Juvenlle Delinquency and Youth Development, Department of Health, Education and Welfare, contributed to the continuing effort of the social work profession to construct 1 ts own body of knowledge. This study has particular s1gnificance for the fleld of corrections as the author, Elllot studt, draws the 111ustrations from that sphere. The author develops her conceptual epproach by use of three dimensions: social problem, social task, and the service system.

Her analysis of service systems ralses some clearcut issues for the present professional soclal agencies. studt says:

\footnotetext{
"The correction organization tends to be isolated from many of the servicerelated decision makers whose heip is necessary for effective resocializetion and restoration. Many officlals such as the police, school administrators, and welfare or recreation workers hold the correctional agency responstble for preventing the offender from causing trouble for them.....This isolation of the organ1zation within the community parallels and reflects the soclal 1solation of the offenders whom it is expected to serve." (56)
} 
Allce Overton suggests an attitude of "get with 1t" rather than fighting against soclety as the important 1ngredient in establishing relationships in correctional work. She feels it is necessary to make clear the worktng purpose, to deal with resistance, convey expectation of and respect for the client, and to use a family focus wherever possible. (57)

Authority relationships have perhaps presented the largest hurdle to certain social work theorists in the correctional fleld, but as Elliot studt points out, all social work uses authority in some way. Eliglbility for public assistance, fules established for group work, the foster-care program, school social work in relation to attendance, regulations established by varying clinical treatment centers, alI use some aspect of authority. Authority in these settings is a legitimatized power which is interxelated with responsibility. (58)

John G. Miner expresses the philosophy of the use of authority by social workers in correctlonal settings:

"The workers have to be on the side of law in their practice. They have responsibility for helping the offender integrate principles of peality that may or may not be pleasurable. Such individuals need support to consider and sace consequences and to learn through these experlences, rather than to evade or escape them." (59) 
Community Resources

The Report of the Priorities Committee sponsored by the Portland Community Counc1l lists the following agencles as offering specific service to the post-release offender: The Governmental agencies of County Courts, Oregon State Parole Board and the U.S. Department of Prom bation and Parole, the Salvation Army and Volunteers of America. (60) Potential community resources encompass a far larger number of agencles.

The Oregon Council on Crime and Delinquency is currently making a study of the Oregon Correctional System With a report expected in July, 1966. Among the several recommendations are the following:

"Current parole and discharge laws and procedures must be carefully revlewed. At the present time the best risks (40\% of the inmates) are released from correctional institutions under the supervision of parole staff, while the poorest risks are released with no parole supervision and in most cases no help to reintegrate them into soclety. Perhaps it would be better to release more on parole under parole supervision and help than to wait a whlle longer and release the same persons with no supervision and no help to re-adjust them to society.

"We should also study what happens to the misdemeanant offender. We know that a great many of the people who go through the revolving door of our clty and county jeils are committed for the offense of being drunk or drunk and disorder ly. Whether these persons are more offenders against soclety or against themselves $1 \mathrm{~s}$ 
a good question. Others who go through the misdemeanant court machinery ma be young people who if not helped may be beginning a criminal career. Counties and cities have little or no probation services for misdemeanant of fenders and ilttle or no rehabliltative programs for those sentenced to ja11." (61)

The California Department of Corrections and Department of Public Welfare conducted a study of the use of avallable resources in meeting needs of inmates and their families. The study was concerned with women prisoners but there is pertinence to this project. Conclusions of the study were: famliles of prisoners need assistence In working out realistic short-term and long-term goals and plans; there should be greater awareness of the consequences of separation in samily group; there exists a need for social services to be assessed for all family members at the time of original incarceration or arrest of a family member; there is need for planning and exchange of information between agencies and Institutions and coordinating services to meet the total family need more realisticaliy; there is evidence of need for better communication and development of procedure at a pollcy level, to be incorporated procedura $11 \mathrm{y}$ by agencies and institutions.

Conclusions

In this chapter we have reviewed some of the literature dealing with meeting the needs of the misdemeanant 
which bears upon the purpose and direction of this project. Baslcally, the current studies in this area show a two-way emphasis: (1) the offender must be helped to alter his deviant behavior by meeting various social, economic, physical, and emotional needs, and (2) society must provide ways to effectively implement or bridge the offender"s return to a satistactory situation.

Research is ther Pragmentary but Wines, Robinson, and Queen glve historlcal background while Turk, Schrag (Cressey), Gibbons, and Zalba are contributors to curpent trends, theory, and developments in the fleld.

From Elizabethan times, the ilterature has reflected serious questions about the usefulness of the jall as an institution. A recent study by Cyril Robinson describes 2 screening process to make alternative plans for the lesser offender. (63) Varlous projects developed to allevlate some of the problems of handing short-term offenders are described. Calirornia studies are excellent In this area. 
NOTES TO CHAPTER IV

1. Dressler, David, Readings in Criminology and Penology, Columbia University Press, New York and London, 1964. Dedication, p. 167-168.

2. Ib1d., pp. 167-168.

3. Ibld., pp. 167-168.

4. Elliott, Mabel A., A Crime in Modern Soclety, Harper and Brothers, New York, 1952, pp. 435-445.

5. Io1d., p. 438 .

6. Ibld., p. 441 .

7. Dressler, Op. C1t., pp. 178-180.

8. Ibld., pp. 178-180.

9. Naess, Sir1, "Comparing Theories of Criminogenesis". Journal of Research in Crime and Delinquency, Vol. 1, No. 2, JuIy, 1964, P. 171.

10. Turk, Austin T., "Prospects for Theorles of Criminal Behavior", Journal of Criminal Law Criminology, and Polltical Science, Vol. 55, No. 4, December 1964, pp. 454-461.

11. Clemmer, Dona ld, The Prison Commun1ty, Rinehart, New York, 1940.

12. Cressey, Donald R., Ed, The Prison, Holt, Rinehart Winston, Inc., New York, 1.961, pp. 310-311.

13. Insid.

14. Ioldo, p. 315.

15. Ibid., pp. 316-318.

16. Mbid., pp. 318-321.

17. Io1d.2 pp. 347-352。

18. Ibid., p. 357 . 
19. G1bbons, Don C., Chaging the Lawbreaker, The Treatment of Deilnquents and Criminals, Prentice-Hall, Inc.s 1965. $\mathrm{pp} .74-188$.

20. Queen, Stuart A., The Passing of the County Jail, deorge Banta Publishing Co., 1920, P. 126.

21. Q1bbons, Op. Cit., p. 192.

22. Ib1d., p. 193.

23. Adapted from G111, Howard B., "What is a Community Prison", Pederal Probation, Vol. XXIX, No. 3, September, 1965, pp. 15-18.

24. Kennedy, Robert $F$. , "Halfway Houses Pay Off", Crime and Delinquency, Vol. 10, Jan. 1964, pp. 1-7.

25. MoMilian, David R., "Work Furlough for the Jailed Prisoner" Pederal Probstion, Vol. XXIX, No. 1, Nerch, $1965, \mathrm{pp} .33-34$.

26. Qleser, Daniel, The Effectiveness of a Prison and Parole System, Bobbs-Merr111 Co., Indianapol1s, T.X., Kansas City, 1964.

27. Hencher, Samuel, "Principles of Soc1al Work Organization". Social Casework, Ny, 1963, p. 262.

28. Current Projects in the Prevention, Control and Treatment of Crime and Delinquency, Vor. IV, Wational Research and Insormation Center on Crime and Delinquency, National Counc1l on Crime and Delinquency. New York, Winter 1964-65.

29. Cibbons, Op. C1.., p. 198.

30. Erikson, Erik H., Ego and the Identity Cycle, International Universities Press, Inc., tew Tork, 1959. p. 18 .

31. Hollis, Florence, Casework, A Psychosocial Therapy, Randor House, NeW York, 1965, p. 16.

32. Erikson, Op. Cit., p. 20.

33. Leighton, Alexander, and Clausen, Jahn A., and Wilson, Robert N. (eds.) Explorations in Social Psychiatry.

Basic Books, New York, 1957, p. 19. 
34. Andry, R. G., The Short-term Prisoner, Vol. 8 of the Inlbrary of Criminology; Delinqueney and Deviant Social Behaviour, Stevens \& Sons, London, 1963. pp. 87-102.

35. Treger, Harvey, "Reluctance of the Social Agency to Work WIth the offender", Federel Probation, Vol. XXIX, no. 1, arch, 1965, pp. 23-28.

36. Helmler, Eugene, "Looking Behina Cold Facts", New Soc1ety, reprint, April 18, 1963, p. 5.

37. Silver, Joseph R., "Citizen Participation in the Held of Corrections", American Corrections I Association, Portland, Oregon, 1963, pp. 80-85.

38. Olsen, Elmer, W., Supervisor, Correctional Casework, Trainee Unit, Parole and Community Services Division, Department of Correctlons, Oakland, California. Letter to Sister Mary Patrick 0'Meara. Coples avaliable in Corrections Project files, Portland State College, Portland, Oregon, November 9, 1965.

39. Zalba, Serap10 R., Women Prisoners and Their Families, Monograph, State of Califormia Departments of Soclal Weifare and Corrections, Delmar Publishing Co., Inc., Los Angeles, Califormia, 1964, pp. 2-3.

40. Ibid., p. 7 .

41. IOIC., p. 3.

42. Friedwan, Sldney and Esselstyn, T. Conway, "The Adjustment of Children of Jail Inmates". Federal Probation, December, 1965, Vol. 29, No. 4, p. 59.

43. Robinson, Louis N., Op. C1t., p. 43.

44. Rubington, Earl, "The Alcoholle and the Ja11", Rederal Probation, Voi. XXIX, No. 2, June, 1965, p. 30.

45. IDId. . p. 33 .

46. Tinsley, Harry C.s and Hunter, Harris G.s "Summary of Pre-release Procedures" American Correctional Association, 1962, p. I80.

47. Hel. Thoms $P_{4}$, and Price, Charles P., "Alcoholism in a Retropolitin C1ty: A Suggested Comprehensive Rehabilitation Program", Amertican Correctional Association, Philadelphia, Peñnsyivania, 1962, p.113. 
48. Regensburg, Jeannette, "The Curriculm Study: Implications for the Practice of Social Casework", Soc1a1 Casework, Vol. 41, No. 1, Jan. 1960, p. 14.

49. Ibid., pp. 14-15.

50. Studt, Elliot, Education for Social Workers in the Correction i Fiela, Council on Soclal Work Education, Wo1. 5, New York, 1959, p. 14.

51. Ibid., Adapted from pp. 15-16.

52. O'Ne11, Carle F., "Intensive Casework with Captive Clients", Soclal Casework, Vol. 40, November, 1959, p. 491 .

53. Mencher, Op. Cit., pp. 262-263.

54. Treger, Op. C1t., pp. 23-27.

55. Studt, Ell10t, A Conceptual Approach to Teaching Mterials, Illustrailons from the fleld or Corrections, Councli on Sbelal Hork Ecucation, New York. N.Y., 1.965, pp. 15-16.

56. Ibid., pp. 25-16.

57. Overton, Alice, "Establishing the Relatlonship in Soc1aI Work": Journal of Crime and Delinquency, Vo1. 11, No. 3, JuIy, 1965, pp, 229-238.

58. Studt, Ell1ot, "Worker-Client Authority Relationships in Social Work", Soclal Work, January, 1959, pp. 18-28.

59. Miner, John Q." "Ireedom and Authority in Social Work" Soclal Work Papers, University of Southern California, Vol. 8, 1961, p. 12 .

60. Priorities Committee Report. Portland Community Counc11, 1962. Mineographed copies avallable Cormunity Counc1l, Portland, Oregon.

61. Moshorsky, W1IIIam V., Ietter to the Honorable Tom McCall, Secretary of State, 2-3-65. Copies avail-able at Oregon Council on Crime and Delinquency. Portland, Oregon, pp. 2-3.

62. Zalba, Op. Cit., pp. 121-124.

63. Roblnson, Cyril D., "Alternatives to Arrest of Lesser ofrenders", Crime and Delinquency, Vol. II, No. Is January, 1965, pp. 8-21. 
CHAPTER V

METHODOLOGY

The central problem was one of studying the unmet social needs of the inmate population of county correctional institution, especially with reference to their post-release period. The social work rationale was that crime and recidivism rates might be reduced if pollce and correctional workers utilized existing social work agencles rather than handling inmate problems themselves or referring then to the courts. Further, it was thought possible that Individuals might avold some of the pressures leading to offenses if they used such agencles.

However, introduction of such a polley of peferral required study of the types and rrequencies of needs, and of the agencles appropriate for referral. This was seen as a brosd and encompassing subject requiring specific1ty in order to handle the problem of "unmet needs" in a systematic manner.

A structured questionnalre interview of inmates was seen as the jor tool for this study, with subsequent statistical andysis.

General Procedure

In the spring of 1965 a tentative time schedule was set up as rollows: 
Spring, 1965: Review ilterature, begin construction of questionnalre, become familiar with the institution.

Summer, 1965: Continue review of 11terature and refine questionnalre.

Pal1, 1965: Administer questionnalre to inmate population or sample and begin analysis.

Winter, 1966: Complete analys1s, study existing social work agencles, and begin report.

Spring, 1966: Complete repoxt.

The elght members of the group selected the committees on which they wished to serve. Early comittees formed were: Blbllography, Leedership, and Editorlal and Writing. All members zere to particlpate in the review of the 11 terature.

The ilterature to be reviewed was divided into six major areas. Each member volunteered or was assigned to cover certain meterial: Psychology Abstracts, Journals of Criminology, Soclology Journals, Social Work Journa Is, Abstracts of Theses, and text books on Criminology, Soc1ology and Penology. Each member was also to be alert for Information pertinent to the subject when reading in areas of pexional interest, such as periodieals, Iaw joumals, monographs, and material 1 sgued by religlous arganizations. The review of the 11terature was limited to witings of the prior five years except for historlcal background and pertinent references which were traced to the source. 
Committees were formed, with three members designated as a leadership group responsible for 11 la ison and coordinstion. Three members volunteered for the Blbllography Comittee and took the responsibility for maintaining the bibliography file. One person was selected to maintain written records and handle correspondence. Three members volunteered to serve on the Editorial and Writing Committee.

Commlttee membershlp was malnly on a volunteer basis and was subject to revision. With the exception of the Treasurer and Secretary roles, each member participated In all areas of the project to some degree. Thus, each individual had some experience in reviewing the ilterature, formulating the problem, constructing the questionnalre, interviewing and administering the questionnaire, tabulatIng data, statistical analysis, and preparing the report.

Al1 members of the group submitted questions for consideration of Inclusion in the questionnaire. A vote was taken on each question by the group. A question recelving a vote of $s i x$ to elght remained. Those which scored three to five votes were discussed and revoted on, and those recelving votes of one or two were discarded. Summer meetings were held for further discussion of the project. There was some need to test the realism of the questionnaire items by mid-summer. Some of the group also lacked interviewing experience with jail inmates. 
Informa 1 interviews were held with four inmates of a jail in an adjoining county. Among the topies explored were their present situations, realistic and unrealistic items to include on the questionnalre, inmate attitudes, best appraaches, and types of needs.

Delimiting the Problem

Pollowing the neeting with prisonexs and a critique of the first draft, the questionnalre was revised.

It was agreed that the questions should include five major areas of human needs in our soclety. Those five areas were seen as:

1. physical needs -- including food, clothing, shelter, and medical care;

2. social needs -- including interpersonal ties, group membersh1p, religious, and recreational needs;

3. psychologicel needs -- including the Individual ${ }^{\circ} \mathrm{s}$ self-concept, attitudes towards accepting help, desire for change, and his present level of achlevement versus level of aspiration;

4. educational needs -- including academic, vocationel, or remedial schooling;

5. Financial needs -. Including post-release funds, debts, and employment.

The emphasis was on those needs which might be met by soolal work ageneles and community institutions.

Considerable thought was given to the language used in the questionnale as some of the inmates would have Iimfted comprehension of abstract terms. Compound and 
complex sentences were avolded. There was an attempt to avold the use of emotiona l language or words that could have negative connotations; that is, words that might disrupt the interview before the final stage, blas response, or Influence other Inmates against cooperating. Quant1tative answers were felt desirable wherever possible and most questions were formulated with categorized response. Discusston was held on scaling of answers and the decision was in iavor of a 100 point scale. That 1s, the Inmates were asked to assign a numerical welght, rangIng from 0 to 100, which would indicate the extensity or intensity of his answer to that particular question. Responses in numerical terms provided the data necessary for statistical purposes and the 100 point scale allowed for finer discrimination than, for instance, a five point scale.

Face sheet information on each inate was avallable at M.C.C.I. There was considerable discussion axound the use of this information. There was a question of interviewer blas if such information were avaliable prior to the interviews. It was felt by some that face sheet information could be used to provide clues for establishing inftial rapport, to check on reliability of interviewee information and to guide interviewing technique. It s decided that face sheet information would be secured after the interview so the problem of blas through foreknowledge 
would be avolded while retalning a check on inmate rellability。

Hypotheses

The alms of the project were approached through the use of null hypotheses in the two major areas of (a) unnet needs and (b) intervlewer rellablilty.

The null hypotheses were the research hypotheses inasmuch as simflarity of needs was expected among the inmates, and reliability could plausibly be expected in a group of simliarly trained interviewers.

This allowed for quantitative estimates of significance of similarities and dissimilarities among the interviewers and with respect to the needs of the men. It furnished a test for the posaibility that an interviewer might inject his own deviant interpretations.

Sub-hypotheses were the null hypotheses of no difference among the interviewers and no difference among the men with respect to extensity and intensity. Subhypotheses referred to specific questions relating to each area of need; physical, soclal, psychological, educational and financial.

Because this was an exploratory study, a considerable number of probes produced data for testing additional hypotheses. Analysis of varlance and Chi-square tests were employed as indicated. Null hypotheses were rejected, if 
slgriflcent difference was shown at the .05 level, with appropriate degrees of freedom.

Pre-test Interviews

Pollowing fixing of the major hypotheses and revision of the questionnalre a pre-test was run. The test was given in the recreation room of M.C.C.I. so that aII members of the project group could give the test at the same time. This was to reduce Inmate bias through preknowledge of test 1tems and communication of att1tudes. Six inmates were selected by the pxison counsellor for the pre-test. Criterion for selection was that the inmate's release was to be within the week of the pre-test. It was expected that the immediacy of facing post-release problems would facilitate focus on these needs and these pre-release inmates would have been thinking about future plans. After introductions and talking briefly about the study, the questionalxe administered.

The 1ninate was told the nature and purpose of the pre-test and study. He was assured of confident1al1ty and that the Individuel. results would not be avaliable to the administrative personnel of the institution. It was impressed upon the lnmo that we were asilng his cooperation for factual information and he was asked to refuse to answer a quetion rather than give false information. He was requested to ask for clarification of any questions 
he did not understand and to make suggestions as to changes in words, format, or additional questions.

Some time was spent with each inmate after the questionnaire was adminlstered to answer his questions and to record suggestions. Each question was rechecked with him to assure that an answer had been recelved or to clarify a particular question or answer. Following the interview the inmate was thanked for his cooperation. He was then requested not to discuss the test in detail with his fellow-inmates. It was explained that, particularly if he should criticize the procedure, he might blas the remaining inwate population and possibly invalidate the flnal testing and the entire study.

The results of the pre-test were discussed in deta11. Recognizing individual differences, the group felt that rapport was readily established and that the Inmates taiked without undue resistance. The consensus wa that Inmates seemed pleased to feel they were part of 2. selentific study and were able to contribute their information. Nothing contrary as observed by 1nstitutional personne1.

Several inmates had felt that some questions were duplicated in two or more areas, and these duplications were removed. The group felt that some of the questions were too difficult to answer and they were revised or removed. Some answer categorles were changed to better 
fit the actual answers recelved rather than the preconcelved expected answers. Some inmates had shown conPusion as to the point in time reference of some questions, 1.e., "What do you like to do in your spare cime?" Ques. tions were revised and clarified by qualifying phroses such as "here at M.C.C.I." ${ }_{8}$ or "on the outside", or "usua11y". Wording and phrasing of questions were discussed unt1. consensus was reached as to clarity of the particular ltem. In some questions where it was felt additional clarification might be requested by some inmates, agreement was reached as to what additional information would be glven.

It was decided that questions which appeared to be least threatening should come first. The areas of self́-concept and post-release needs had been recognized as potentially threatening to the inmate and had been placed toward the end of the questionnaire. In the pre-test situation the research group had divided, with half the Inmates being ssked those questions regarding education first and the other half being asked those questlons regarding marttal status and famly situation first. Consensus was that efther area was acceptable as a starting point as there had been no difference between the quality of the answers to the questionnalre as a whole and the starting place. In lts fina I form the questionnalre began with the family situation. 
The major accomplishments of the pre-test were:

1. Known exrors in the questlonnalre were removed and questions added. Some near-duplications of other questions or of institution records were built into the questionnalre to serve as checks of reliability.

2. The use of the questionnalre was Informally validated \&s a structured, quantitative instrument for eliciting information from the jall inmate.

3. It provided an opportunity for the interviewer to become famsliar with the staff, the population, the environment and the interviewing situation.

4. It built conflidence in the intervlewers, through experience.

5. The necessity was shown of conducting the interviews in private.

Construction of the Questionnase

A copy of the final form of the questionmalie is Included a Appendix A.

When questions were submitted by group members for considergtion it was found that questions were formed acording to Individual arees of interest, srequenty influenced by the specific area of literature reviewed. Considerable time was spent in discussing the merlts of Individual questions before the deciston was made to be mgorous in limfting questions to those furnishing 
Information on needs which could be met by social work agencies or community institutions.

First drafts of the questionnalre included questions regarding affectional ties of chlidhood, sibling rivalry, favorite school subjects, how they ranked the nelghborhood of their youth, military service, feelings about being spanked, and whether they had a favorite teacher. These were discarded as unwarranted considering the focus of the study.

Other questions were discarded following the pretest, such as, "If you were completely alone, jobless, and penniless, how would you feel?" The consensus was that such \& hypothetical question could have a residual negative effect on the inmate even if it were of value in elialting feeling tone under adverse clrcumstances.

In its fingl form fnadvertent duplications hod been discarded and the questionnalre had been divided into gross categories, such as:

Family situation lincluding the number of friends and nembership in groups);

Buployment lincluding estimated annual income, type of worker, and type of work usually followed);

Soejal interests fineluding religlous interests, perreationel cholces, and chosen compantons for such recreation);

Self-concept fincluding how he seer himself as an 
Individual, how he gets along with others, and how much he thinks others 11ke him);

Incarceration (Including what Inmate likes and dislikes about present situation);

Post-release needs (Including Immediate and longterm needs).

"Post-release needs" was seen as the core of the study. Fifteen categories of need were ilsted and Inmates were requested to identify pertinent areas, with answers on a point scale as to the extensity of this need. These fifteen categorles of need had been selected for inclusion on the basis of personal experience, pre-test information, revilew of the I1terature and professional training. These needs were: job, money, housing, clothing, family, educational, medical, recreation, religious, legal, fine, garm1shee, license, amount of money (owed), and all other. These are primarily concrete needs, with varying specific1ty.

The general tone of the interview situation, the seapport between inme and interviewer, and the specific questions, with allowance in "other" for unlisted needs, were positive factorg in ellating the data.

Another dimension inguired as to how important fulfiliment of this need (Intensity) to the individual. Subsequent questions in chis ares were designed to probe inmote awareness or possible reasons for unfulfilled needs and any type of help he might have prevlously utilized. 
Croteria for Selection of Interviewees

Thelpe was some question as to the stae of the sample of the immate population to be interviewed. The concerm was how to Iimit the sample in view of the time avallable while lncluding a sufficlent number to allow valld inferences from the stat1stical analysis of the data gathered.

Although Hultnomah County Corrections I Instikution has the capacity for population of 125, the average monthly population was about 80 , with approximately 20 releases and 20 new innates per month. On the basis of this Information the decision was made to 1ntervlew the total population present as of November 15, 1965, excluding the following:

3. Men interviewed in the pre-test who might have returned:

2 - Men due for release before December 30, 1965. It was thought advisabie to have the men avaliabie while data were belng tabulated should clarification be required on pyrticular questionnalre:

3 -Three inmetes who were on "work-release". (3)y "wonkmelease" was meant gainful employmert ln the communty with return to the institution each night.)

With the above excepticas, the total population as

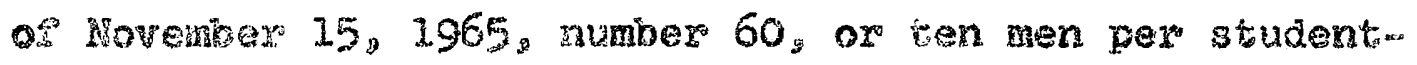

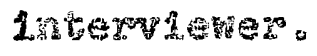


An unbiased method of assignment of inmates to interviewers was used. The procedure was for the instifution to schedule one man per interviewer-hour available on any particular day. Interviewers drew from the pool of scheduled men with no order. As one interview was completed, the next man was called in.

Those inmates who were to be released the soonest were intexviewed first. Consideration was also given to Inmate jall work assignment, to avold conflict with heavy mork periods. Interviewing was not done at night. It was felt by both the research group and the fall staff that inmates might be resistant to giving up their free time for such a purpose.

Administration of the Questionnalre

Essentially the same procedure was followed for the testing as had been used for the pre-test, but there was mos privacy. On the scheduled Interviewing days there were two sms ll offlces put at the intervlewers ${ }^{2}$ disposal. that of the Egychologlst and that of the Chaplain. on days then three Interviewers were present, the Chapel section of one wing was used. This was not a completely enclosed area but there was surficient space between this ares and the Ilbrexy to assure confident1al1ty of the conm versation, if not privacy.

Each man was called to the central area by the 
officer of the day. He was met there by the interviewex, who Introduced himself, and led the way to the site of the interview. When both interviewer and inmate were seated, the purpose of the study was explained and the confidentialty of the information was emphasized. Although the full name was not requested for the face sheet, often the man's name had been called out when he was summoned to the interview, one reason the concept of confidentiality had to be stressed.

It was further explained that the study might be of value to future prisoners in this or other institutions but that there was no direct benefit to the respondent. He was asked to cooperate as h1s contribution to a scientifle study which might help athers. He was requested to answer to the best of his knowledge and to refuse an answer rather then provide false information which might blas the results. After establishing some rapport between interviewer and Inmate with the non-threatening questions on the sace sheet, the questionmaire was administered. When the inmate requested clarification of terms or questioned ambiguity or repetition, an explanation was given, but the structure of the questionnaire was mantalned as closely as posstble. When conpleted, the questionnalre was revlewed to be sure ali pertinent questions had been answered. Any inmate questions relative to the quastionnalre and the study rere answered but discussion of his persond problems 
or entering into any counselling relationship was avolded. Each man was assured of the value of his cooperation and thanked for his particlpation.

Subsequent to the interviews, data were collected from the jall records regarding the age, schooling, length of sentence, and charge, for each informant. Neither psychological data nor a past record were avallable for every man so such factors were not included as a part of the strudy :

Interviewing was completed by December 14, 1965. One re-interview was necessary due to the absence of one sheet in a completed questionnaire, not noted at the time of the interviews.

Tabulation of Data

Each intervlewer tabulated all answers for his questionnalres, Hith the axception of those questions requiring open-end response. Key questions were checked Independently for accuracy. The subjective weights on the hundred point scale given in quantitative answers (extensity and intensity) were totaled and the arithmetic means were figured.

Face sheet data from the prison records were handled in the same nanner, and the items of "Age" and "Place of birth" which appeared on both the prison record and the questionnalre were checked for agreoment. Such 
agreement was one indication of Inmate reliability in this situation.

By the use of this procedure, each interviewer had a tabulated summary of his set of interviews. Sub-total data were thus useful in checking possible differences anong interviewers, and computing error.

The interviewer sub-totals were then tabulated on master sheets for total population data. Open-end questlons (those where inmate responses were not conflned to pre-specifled categorles) and "other" categories bere I1sted and categorized from the origingl questionnolres. Then both quantitative and open-end answers were studiad and compred for relationships.

Statistical Analysis

As previously stated, It was believed that the number answering and the scoring given to the categorles covered in post-release needs were the core of this study. merefore, the first stratistical tests pertalned to this particular question. With emphasis on the most frequenty Indicated, the need for a job.

It was considered that those men who were married might indicate more "needs" than those who were not narried. It was also hypothesized that femile interviewer might ellet more responses in the "need" ares than the le intervlewers, by virture of the totaliy maculine environant. 
A Chi-square was used to differentiate married-unmarried inmates and assignment to ma or female interviewerg. An analysis of variance was used for all answers to this particular section for each interviewer, to indicate within group differences of interviewers.

Other Chi-square tests were employed when indlcated. Spec1fic tests will be reported in the next chapter in conjunction with the respective findings. 


\section{CHAPTER VI}

\section{FINDTMGS: DESCRIPTIVE}

The chrpter on methodology has described the meetings, division of labor, construction of the questionnalre, pre-test, revision of the questionnalre, administration of the questionnalre, and tabulation of the data.

In this chapter findings will be examined. A summary of all questionnaire responses is supplled as Appendix $B$ for those readers who msy be interested in the results which were not andyzed.

The total number of Inmates interviewed was sixty. However, one inmate who reported for his scheduled incer vien refused to participate in answering the questionnalre. He told the interviewer he had not comitted the offense for whlch he had been sentenced. He was serving his time and thought this was all the law required. He "wanted no part of the research study." This was his declsion and no coerclve techndques were utillzed to attmpt to change his mind. For this feason, the greatest number of men answerm ing any question is 59. When referring henceforth to the populatofon, it is these 59 respondents to whore referance is made. Some of the demographic data has an of 60 because this infordion was obtalned from the fail record rather that Prom the Irmote. 
Demographic Data

The needs of the population of M.C.C.I. were many, and they were widespread, but before examining these needs, it would be weli to examine the population exhibiting them.

Race: Racial and ethnic minority groups were represented in the population but the majorlty were Caucasian. Race was not one of the varlables studied.

Age: The arithmetic mean age of the sixty men under consideration was 29.5 years, with a range from 17 to 62 . Thirty-four of the men were age 25 or under; fourteen were from 26 to 40 inclusive; and twelve were in the 41 to 62 age bracket.

Education: Seventeen of the men had from one to nine years of schooling. Thirty-81x men had 10 to 12 years; of these, fourteen had elther graduated from high school or received the G.E.D. certificate which is the equivalent of a high school diploma. None of the men had completed college although seven had one or two years of college. Vocational or "on the job" training was not elleited. The arithmetic mean years of education was 10.18 years.

Length of Sentence: These sixty men had been sentenced to serve a total of 15,972 days, almost 44 years. The arithmetic mean sentence was 266.2 days, with a range of 30 to 730 days.

This mean requires some interpretation. Two men 
were serving consecutive sentences on two charges. In both of these cases, the maximum sentence for one charge was one year, which is in accord with the statement in Chapter I regarding the usual maximum sentence for a intscemeanor. However, as these two Inmates were serving total of 605 and 730 days, respectively, these figures were used in computing the average length of sentence.

The median figure for length of sentence was 205 days. Hialf the population were serving less than 205 days and half were serving more.

The modal length of sentence (being served by the greatest number of men, 1.e., 28) was 180 days. Th1s 180 days" sentence was given for vartous types of offenses and does not reflect a standard sentence for any particular charge.

Orfenses: What are the offenses for whlch these sixty men have been sentenced to serve almost 44 years of their collective time?

One-third (20) of the offenses lnvolved driving a motor vehicle. Seven men were sentenced for driving with no operator's Ilcense; aix for driving while their licenses were suspended; seven for "other" driving offenses, 1neludIng fallure to leave name at accident, resisting arrest, and eluding police. One man was serving tine for "driving under" the Influence of alcohol."

One-fourth (15) of the offenses were larceny (4) or 
petty larceny (11). The differentiation is one of degree, not of kind. In Oregon one is gullty of petty lareeny if the value of the stolen property is less than $\$ 75.00$; of laxceny if the value of the stolen proparty is more than $\$ 75.00$.

One-sixth (10) of the offerises were drinking or alcoholism。

One-twelfth (5) of the offenses were categordzed as NSF checks. This NSF stands for "non-surflcient funds" and means the Individual cashed a check or gave one in return for merchandise, etc., having insufficient money or no morey in the bank to cover the check when it was presented to the bank for payment.

Of the remalning ten men, two were charged with "recelving and concealing" stolen property; two were charged with "vagrancy"; s1x were 11sted under the "other" category, which includes defacing bullding, assalt and robbery. parole violation, having a concealed weapon, and unlawiuliy seling reglstered securicies.

Charta 1,2, 3, and 4 (Appendix C) summerize the data for age, educstion, length of sentence, and current offense.

Relationsh1p Between Age and Ofrense: A scattergram was drawn to find potential relationships between age of the offender and the offense for which he was currently charged. 
A preponderance of driving offenses were clustered In the 25 and under age group. Only three driving offenses were charged against older men, two of age 38 and one of 41 . Drinking or alcohollc offenses were found for all of the age groups shown in Chart 4. The 18 year old charged with "driving under the Influence" could be categorized under either driving or drinking offenses, so this was listed separately to avold confusion.

The larcenous offenses were also found in all age groups but nine cases clustered in the 25 and under group. The NSF charges were not found in the younger group. The ages in this charge category ranged from 28 to 45. Enployment and Income Date

According to the U.S. Department of Labor, average annual earnings in 1962 for full time employees fexcluding farm labor) were $\$ 5,013$. How does the population M.C.C.I. In 1965 compare with this natlons average?

Income: Ten of the Inmates were unable to est1mate theix yearly income. These vere some of the youngex men who had brief employment records or had held only part-time jobs, and lived with their parents. They had never supported themselves.

With the remoining $49 \mathrm{men}$, income figures were dew rived from hourly, weekly, or monthly renuneration, projected to an annual estimate, based on the average length of 
time employed each year. In a few cases, the men remembered thelr gross income for the previous year.

The ardthmetic mean for the annual income of the 49 men was $\$ 4,472$, w1th a range from $\$ 200$ to $\$ 18,000$. The lower figure was reported by a man who sald he had not earned more than $\$ 200$ a year for some time. The $\$ 18,000$ was the stated income for a salesman. These extreme figures neturaliy affect the arithmetic mean. The median of $\$ 4,125$ and the mode of $\$ 5,000$ (Na7) reflect more real1stic picture of the population.

Chast 5 (Appendix C) summarizes these data for annual Income. Also given are charts reflecting on the general type of work performed (chart 6) as well as the line of work (chart 7).

登ind of Woriver: This category was an evaluation by the inmste, reflecting his own Idea of the degree of skil1 irequired. If there appeared to be confusion in differentiating between skilled and semi-skilled, "skilled" was explained as usualiy implying some technical or vocatLonal tralning.

Slxteen of the 1mates considered themselves slcliled workers, (Including the $\$ 18,000$ a year salesmen): Twentyone men considered themselves to be semi-skilled, and twenty-one were casul laborers. One man sald he was a casus I laborer but had no trouble in finding employment bew fause he was sem-skilied inasmuch as he had considerable 
ability in fixing equipment or making minor automotive repairs.

Line of Work: This category was deslgned to reflect the stability of employment on a time dimension - steady, seasona 1, and odd-jobs. Steady implies continuity in the same or a similar type of employment; odd-jobs has the connotation of sporadic or periodic employment, moving on as the fob is completed; seasonal work includes the harvest or agricultural crews.

A construction worker consldered himself to be in the "steady" category although his work was regular but not steady. He did not seek other employment during the ralny season but lived from savings or went into debt. He was one of 34 inmates who considered their work steady. Sixteen men replied "odd-jobs" and elght men replied "seaw sona I" to this question. One man, mechan1e, took steady work when he could find it but did oddojobs when necessary. Another inmate consldered himself to be primarliy a harvest worker (seasonal) but did add-jobs if someone approached him with a job.

Three sources of difficulty in interpretation arose with respect to these kinds of work. The categories were overlappling, (the men could be in different categories at differenctimes) and some men tended to respond to meanings not intended. These difficulties were anticipated, but other considerations intervened. The use was justified in 
that results reflected acturities and were readily interpreted.

Has a Job Wa1ting: Some post-release needs would not be extensive if a job were walting for the inmate. Chart 8 categorizes inmate answers into yes, no, or maybe, regarding this situsicion. Twenty men of the population of 59 expected to return to their former employer and sixteen thought maybe they could get their old job back. Twentythree had no job prospects and did not lnow where they could find a job.

Marital and Parental Status of Inmate Population

The marltal status and parental status of che Inmate population are shown in Chart 9 and 10. The mried and divorced categories reflect some overlap, not discovered until the figures were tabulated. Some of the men had been divorced but were currently legally married, and they answered yes to both categories.

Twenty-two inmates had never been married. Twentysix were, or had been legally married, but only nine of these men were living with their wives. Elghteen men had been divorced. Three men had a "common law" marriage which is not a legal status in Oregon. Fourteen were living apart Pron their wives.

Twenty-seven of the men were fathers. Twenty-three were fathers to a total of 49 chlidren under the age of 18. 
These children ranged in age from 2 weeks to 17 years. Nean number of children was 2.1 .

An attempt was made to ascertain the percentage of inmate income which was going to the supgort of dependents. Twelve men indicated they were supporting children. There are therefore eleven men who were not supporting their hypothetical twenty-two children, based on mean number of children. Of the twelve men who were supporting their children, the extent of their contribution was not tabulated aue to interviewer variance in interpreting this question.

Reeds of Inmete Population

In this study of the inmate population an attempt has been mede to elleit data on needs of Immediate postrelease urgency and long-range needs in such areas as employment, health, education, welfare, and family needs. other data which may be useiul for inferential purposes were gathered in the areas of self-concept, soclal interests, and how Immates react emotionally to present incarcoration. These unmet needs, particulariy employment, health, eduction, welfare, and family needs, could in large measure, be met by social work services.

Our major hypothesis states:

Hypothesis I: Irmates of H.C.C.I. have unmet needsu prior to incarceration, during incarceration, and upon 
release-which could be met or alleviated by social work. social work agencies, or communtty institutions.

This hypothesis is supported by inspection. The answers to questions \#38 and \#4I respectively show a total of 59 men listing 102 post-release needs and 320 long-range needs in both specific and general areas.

The Community Counc11, Portland, Oregon published a booklet, Where to Purn, which is a directory of health, welfare, and recreation agencies. Problem areas iserved by Qgencles Include: Aged, Alcohollsm, Child Welfare, Employment and Job Traiming, Family and Personal Problems, Flnanc1.1. Ass1stance, Handicapped, Housing, Inter-Group Services, Iegal Advice, Redical Care, Recreation and Informal Educetion, and Veterans and Armed Forces.

In large measure these 102 Immediate post-release needs and the 320 longmrange needs could be met or alleviated by the social work agencies and conmunity institutions Ifsted in the varlous sections of where to Turn. However, either through lack of knowledge or subjective feeling about seeilng help the inmates do not approach the agencies for help with unmet needs.

Other needs seen by the Inmites Included a driver ${ }^{\circ}$ Iicense. There is no agency per se to supply help in this area. Obedience to the law and resociallzation appear to be indicated and the fact that prevalence of this need wa in the younger men (25 and under group) indicetes that 
driving offenses diminish with age. Inferential analysis suggests that alleviation of this need could be perlpheral to more adequate personal adjustment .- which is a service rendered by existing agencies.

Specifically, what are the needs the inmate sees as unmet? Questions were clarified with the explanation that needs were things that "would help you stay out of trouble with the law. Help you get along better on the outside". This clarification may be seen as an ambiguous interpretation of the definition of need as given in Chapter I but It appeared to be comprehensible to the inmates. However, the concept of help as a need for some individuals in adjusting to both the expectations of, and the opportunities offered by society is basic to the profession of social work and was assumed to be a primary need of this populaEion.

Data on the needs of the inmates were gathered regarding the inmediate needs on the day of release and for Iew days thereafter and how the mexpected to meet these needs. The second dimension, on long-range needs, contalned 15 categorles, one residual, which the research group consldexed to reflect aress of need with a future orfentation.

The men were asked to consider where they wanted to be, soclally and economically, in terms of employment; whet they would like to have, in terns of material wealth; what they saw as necessary to enable them to become "solid 
citizens" in the future. Then mutual consideration, by Inmate and intervlewer, elicited means towards the goals of the finnate. Thus, many of the needs isted axe conerete necessities, such as medical ald, whereas others are means towsrd a more favorable goal, such as education.

The men also gave information regarding family needs. Similar explanations were given, that 1s, what did the men think their family might require to enable members of their family to function more adequately?

Inspection of the answers show the inmates indicated a "Iack of something required" in the flve major areas of need: physical, soctal, psychological, educational, and finencial. Some are specifically identifled as needs by the inmte. Others, however, were found by inference, but not imputation. For example, the allenation by choice of this population from group interaction was inferred from the small number of groups they sought.

Regarding the more speciflc needs, if an inmate did not indicate a particular category as one of his unmet needs, it was assumed that he was meeting this need to his satisPaction. No attempt sade by the interviewer to indieate whet a social worker might see as a need for the individual. The question regarding immediate post-release needs called for a spontaneous rather than a categorized response. Angmers were reveding of the current level of functioning of the individual and served as an excellent point of 
departure for probing into long-range nesds.

Imnediate Post-Release Needs: On the day of release 22 Inmates felt they would need a job; 20 would need money; 17 would need clothing; 12 would need lodging; and eight would need transportation. Nineteen men replied that they needed "nothing". Of the elght men needing transportation two men needed a ride to town; one man wanted "the next freight train to Nevada", and one "needed a car" to "get any kind of a job".

Responses to question $\# 39$ revealed that there were some resources in the background to meet the above needs. Fourteen had savings, eamings, or, "personel resources". thirteen expected their ramilies to help; eleven hoped to find employment; four were going to a social agency; three had friends who would help; ten had no ldea how to meet these needs.

In the summer meeting of the research group with four inmates of the Washington County Jail some time was spent in discussing post-release immediate needs. These four men were emphotic in their endorsement of suggested "center of operations" where they could, for Instance, recelve telephone messages from prospective employers. As one inmate said:

\footnotetext{
"I've got one buck. There's no work money here so that one buck, plus the clothes on my back are all I've got. I don't dare even buy a toothbrush. I'm $22 \mathrm{mil}$ les from Portland and I'II walk to there or hicch a ride. I'lI plck up a used newspaper to look for jobs.
} 
I can't call many to see if they're still.

open -. I can't go out to see more than two, even walking back to town. The cops will pick me up for vagrancy before I get a job -. they always do."

This man wes alienated from family and friends possibly an extreme case. However, two of the others reported being in a similar sicuation except they could temporaisly "bunk in" with frlends or relatives "but not for more than a couple of days". Their friends and relatives were having subsistence problems of their own, according to these men. These Washington County inmates pere not alone In having this feeling.

As previously stated, the research group avolded personal counseling with the inmates they were interview ing, but the raport was such that difficulty was frequentily experienced, in terminating the interview. The men seemed eager to talk in the majority of cases, and the problem most frequentiy discussed was "What am I golng to do the first sea days after" I get out?" In other words, where do 20 men go for money, 17 for clothing, 12 for lodging, and 8 for transportation? True, the earnings from work in fa11 are given to the Inmate on his release. Based on the modal sentence (180 days) and $25 \%$ per diem earnings (approximately $\$ 1.25$ per week for 26 weeks) Inmates could have funds or between $\$ 32.50$ and $\$ 39.00$ on release. This amount does not last much are than a werk, spealking realistically of today ${ }^{\circ}$ sostm- of -iving. For the single, homeless man seeking 
employment, needing clothes, traveling by public transpor-tation, at cetera, it may be adequate. What about the man with a family, the 111, the unemployable, the alcoholie?

There are also psychological and social implications to conslder but they cannot be included here. The question may be raised though as to the degree of self-respect and autonomy any man can feel when he $1 \mathrm{~s}$ alone and friendless, with a rapidy dwinding supply of money. If his affectional ties are to an ant1-social or asocial group in the community, how well motivated is he to break these ties and form relationships more acceptable to society?

Long Range Heeds: The question regarding long-range needs was not predicated on chronic conditions such as need for a job or money. This question was designed to measure what the Inmate saw as a need in order to build a better Iife in the future. Some who answered "job", or "house", following some probing were found to be referring to 2 better job, or a house rather than a rented apartment. In other words, the fact that thege are seen as long-range needs, or galls, for the future, introduces a time dimension which would allow for seli-improvement in order to better attain these long-range needs. During this time lapse -- from seeing certain need to attalning that need - - Is the perlod when soc1al worle services could be utllized. That 1s, such services could be utilized assuming the individual (I) was aware of 
the existence of such agenc1es; and (2) was motivated to use the services.

Question $\# 4.1$ relates to long-range needs as the inmate saw them. These are shown, ranked according to mean extensity, how much this is wanted or seen as desirable, in Chart 10. Also shown is the mean intensity, the importance of this particular need to the inmate, which is obtained from question \#42. The differentiation was difficult for some of the inmates. At the time the questionnalre was drawn up, it was felt by the research group that the logic was sound.

In an attempt toward bullding theory, the thought behind measurement of these needs on two dimensions exm tensity and intensity) was that a higher intensity rating (as compared with extensity for the same need) would be a crude measure of the effort the lndividual might expend to achieve fulfillment or alleviation of this need.

This could be schemetized as a simple ratio:

$$
\frac{\text { Intensity }}{\text { Extensity }}=\text { Effort to achieve }
$$

It was felt that the greater the answer was beyond 1.0 , the greater would be the potential effort.

As anticipated, there were differences between the extensity and the intensity of needs, as seen by the inmates. In 3 ome categories the extensity of the need was given hagher weight than the intensity, the importance of this need to the individual. Needs for job, housing, license, 
medical care, clothing, money owed, legal services, and garnishment were scored by inmates to this effect. Comments from the inmates regarding their answers indicate that they felt these needs would be ot least partially met in some manner. Public welfare, missions or health clinics could be ut1lized. Need for a license could be met by moving to another state. Garnishment or threatened suit for money owed was dismissed with remarks such as, "You can't get blood out of a turnip".

Six categories, Including "other", education, famlly, fine, recreation, and religion, were found to be velghted lower as to extensity of the need but higher in intensitys or Importance to the individual. AII intensity and extensity P1gures for long-range needs are shown in Chart 10. Pox the above six categorles the ratio between extensity and intensity, where intensity was the higher mean, were:

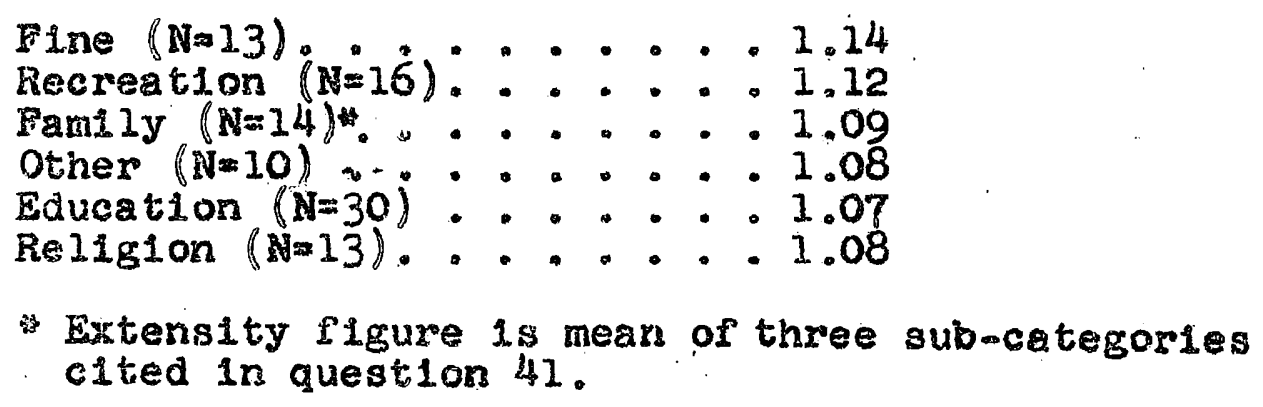

With the exception of the education category, the number of men citing these as needs was small. The ratios between interist ty and extensity of reed are minor and did not appear to be significant. The low ratio could be due to (1) $1 \mathrm{rg}^{\prime} \mathrm{ter}$ Vlewer variance in scoring, (2) inmate difficulty in 
discrimination, or (3) low effort to achieve.

All socletal factors being equal, there are undoubtedly other variables which affect the goal-directed behavior of the adjudicated law-breaker upon his release. The amount already possessed of the item the inmate sees as lacking or desirable, the intensity of his desire to attain or possess more of this 1tem, the time it will take to attain this goal in a socially acceptable manner, all are highly important factors in determining future behavior in an individualistic society.

Th1s logic may be schematized by a formula based on a goal-airected theory of soclally acceptable behav1or. In this case, 11 behavior is assumed to be related to the amount of tension required to achieve a goal, then the tension is related to the amount of the Item possessed; the amount desired; the intensity of the desire; and the time it w1II take to attain the goa I by lawful means.

$$
\begin{aligned}
& \mathrm{E}: \mathrm{B} \text { Where } \mathrm{E} \text { is tension, } \mathrm{B} \text { is behavior } \\
& \text { and : indicates a measure of } \\
& \text { correlation } \\
& E=\frac{D V_{1} T-1}{V_{2}} \\
& D=\text { Intensity of desire } \\
& \nabla_{1}=\text { Amount desired } \\
& T=\text { TIme the goal is ahead of } \\
& \text { present } \\
& V_{2}=\text { Amount possessed }
\end{aligned}
$$

The time element bears a negative exponent so theoretically the greater the time span (between the present and achlevement of the goal by non-deviant behavior) the greater the possib1lity that the non-deviant behavior w11 be abandoned. 
The tension (E) may be reduced in three ways: (1) lowering the intensity of desire; (2) adding to the amount possessed; or, (3) lowering the amount seen as destrable. The use of social work services may help the individual in managing the tension by: (1) personal or group counsel1ing toward more realistic thinking about the intensity of desire or the amount desired; (2) supplementing the amount possessed (placing client in contact with agencles who function in this specific area, that is, employment and tralning services, medical services, etc.); or (3) helping the client set short-term goals towards the desired end which may be more realistically attalned.

On the other hand, if tension cannot be reduced nor garl satisfaction postponed, recidivism is more likely to be the outcone.

These other significant variables were beyond the scope of this study and demand a more rellable instrument than the structured questionnalre interview utilized herein. However, the logic appears to be sound and the more complex formula ma have heuristio value for future exploration. Needs of Greater Extensity: Job, Money Housing: Chart 11 summarized the data on the long-range needs; mean extensity (column 2) and intensity (column 5), range of extensity (column 3), and number of inmates citing this as need (column 4).

The inmates felt their greatest need was a job, with 
42 of the 59 inmates (71\%) stating this was a need. This also recelved the highest mean extensity (92.8) and intensity $(90.8)$ on the hundred point scale.

Money was c1ted as a need by 40 of the 59 men (68\%). The extensity mean was 88.5 and the intensity mean was 84.7. Some of the inmates said that money was not too Important per se, if they had a job. "If you have a job, you can get what you need. If you don't have a job then you need money." Probing elicited further information which indicated that the respondents lived from pay-check to pay-check and they interpreted the need for money to mean savings, compensation, or welfare.

The need for housing was given by 25 of the 59 inmates (44\%) with a mean extensity of 86.9 and an intensity mean of 78.6 .

Fourth in rank order of extensity was the ilcense category. This was seen as a need by 31 of the 59 inmates (53\%). Extensity mean was 81.4 and intens1ty mean was 77.0 . The residual category recelved the second hlghest mean intensity, 87.1 , was cited by ten men (17\% of the population), and had an extensity mean of $81.0 \ldots$ or fifth in rank order of extensity.

Additional comment on these findings will be found in the following chapter.

Needs of Lesser Extensity: Five categories of need recelved mean extensity ratings of 70.0 to 75.0 . Twenty-two 
men need medical attention, with a mean extensity of 74.9; 22 men need clothing with a mean extensity of 74.3 ; 22 men show need regarding the amount of money they owe (excluding current fine, if any) with a mean extensity of $74.1 ; 30$ men need educetion with a mean extensity of 72.3 ; and 15 men show need in regard to their families, with an extensity of 70.0 .

The five remaining categories of need were cited by the fewest men and with the lowest degrees of extensity. Eleven men indlcated need in the legal category with a mean extensity of 69.1 ; seven men indicated need regarding actual or potential garnishment, with a mean extensity of 65.7; 13 men indicated need regarding a current fine, with a mean extensity of 56.5 ; 16 men cited need in the recreational category, with a mean extens1ty of $53.7 ; 13$ men had religlous needs with a mean extensity of 51.2 .

Self-Concept or Inmates

How do these men feel about themselves? How do they feel about the society they live in -- more specifically, the soclety of the non-deviant? How do they interact with others outside of the institution? These are important questions in determining psychological needs of inmates. The questions in the Self-Concept area of the questionnalre were an attempt to elicit data for inferential purposes. Ben were asked "What bothers you most about yourself?" 
Seven categorles were given to be evaluated, including one reslduel. Self-consolousness, aggress1veness, and lack of self-confldence were traits indlcated by 20 inmates and the mean intensities for these traits were $67.1,65.0$, and 65.4 respectively. In the residual category 27 inmates stated irresponsibility (9), impulsive behavior (9), lack of training (2), and low self-concept (4), bothered them to a mean intensity of 79.6. Such 1tems as personal appearance and mental abilities were ranked by three and six men with mean intensities of 43.3 and 54.6 respectively. It is of interest to note that the traits which most bothered the Inutes were 211 in areas which might be changed if the inmate sought help.

Inmetes were asked if they had tried to overcome the bothersome tralt clted in the preceeding question and if so, how hard they had tried. The highest mean extensity for trying to overcome the trait was 49.4 (self-consclousness), rollowed by 40.7 (residual category), and 40.6 (physical appearance). The mean extensity figures indicate to the research group that, while the inmates know some of the tralts which interfere with more adequate adjustment to 118 aituation they have not tried very hard to overcome these traits.

What methods had been employed in trying to overcome these factors? Thirty-seven Inmetes had talked to others; 13 had help from counselor; and $81 x$ had help from a 
teacher. Elght had gone to a social agency in an attempt to allevlate what bothered them most about themselves.

Six categorles, one residual, were given to ellcit information regarding positive attributes and the extensity of these good tra1ts. Forty-four of the 59 inmates (75\%) considered physical skills as one of their better qualities, with a mean extensity of 76.2 . Th1s was most orten a reflection of his work on the job rather than an interest in sports. Thirty men considered their moral qualities to be a positive factor, to mean extensity of 70.2 . Twenty-nine men cited personality fmean extensity, 72.4), 28 men sald mental abilities (mean extensity, 71.2 ), and 27 said leadership (mean extensity, 59.6).

In reply to question as to what they thought would need to be strengthened to help them stay out of trouble, 37 answered "better understanding of themselves" and four sald vocational or educational tralning. However, in another question asking what would help most in staying out of trouble, but calling for sponteneous response, spec1fics mentioned most often were staying away from alcohol (12) and holding a job (17).

In this same category of self-concept, Inmates were asked if they usually got along with people. The mean extensity of this answer was 76.9 with a range of 25-100 $(N=59)$. This difference in evaluation of how the inmate "gets along" with others and how well he thinks others like 
him (mean extensity of 70.9 , range 10-1.00) could imply a belief on the part of the inmates that they are making more of an effort to be acceptable to society than society is making to accept them.

Many Inmates Loners

Despite the median age of 24 , with the implication of group affiliation and interaction continuing from edolescence, the inmates were found to be quite interested in dolng things by themselves. When asked how many close friends or buddies they had the nean number of friends was 3.6. One of the younger immates stated he had fifty; th1s raised the mean value. Twenty-five of the inmates stated they had none and all other answers (33) were fifteen or under.

They were also asked what groups they were in including labor unions, bowling teams, or soclal clubs. The mean was less than one, with range of $0-10$. Similar to the answers on close friends, 32 of the inmates answered none.

The intes seemed to be quite ambiguous about how much of shock their srest and Incarceration was to those who knew them. Answers ranged from "I haven't let anybody lmow" to "ly old man's been teling me it would happen for years". They indicated little worry about these significant others and did not believe their own arrest and incarcerar tion has caused much trouble. 
Extensity of inmate association with their familles had a mean of $61.7(N=59)$ which indicates a degree of allenation from the family of origin. Another question which might indicate allenation (How do you get along with your wife, family, friends?) recelved a mean of 59.4. Comparing this mean with the mean of 76.9 for "getting along with people" reflects some ambiguity on the pert of the Inmates regarding the depth of relationships with others.

The Inmate was asked if he talked with anyone special when he "needed to talk things over". Twenty-eight of the innates answered in the negative. The 31 who answered in the affirmative were then asked to ldentify the person. Twenty-one sald a member of their nuclear family; twelve said friends; nine said a member of the extended family; three sald wife; and four sald a professional person.

Parents and relatives were clted as helprul persons by 32 inmstes but parents and relatives were clted as least helpful persons by nineteen other Inmates.

The Inmates showed little interest in group therapy on a non-professional level -- this question recelved mean extensity of 23.7. Croup activity of any type was not favored. Rany of their cholces for spare time activity may be done elther individualiy or with others present but with little interaction occurring (TV, reading and studying, hobbies, spectator sports, etc). When asked their cholce of companion for chosen free-time activities there was 
overlap in the answers, as some inmates had given two or three activity items, some of which, such as tennis require a partner. Forty-three like to do their spare-time activities with friends, 36 preferred activities which could be done alone, 13 plcked relatives, elght chose the1r wives and three chose their children, as companions for sparetime activity.

With this apparent tendency toward 1solation and allenation, the inmates have specifics they cite as their main worries. In line with the findings on needs, job is highest on the list of worries, receiving an intensity of $89.0(\mathrm{~N}=32)$. Worry regarding chlldren was next, with an intensity of $86.9(N=18)$, followed by money, 33.7 $(N=22)$, and other, $82.7(N=28)$. This "other" category included worrles about the future, alcohollsm, behavior, family, incarceration, 11cense, education, and housing. Twelve men worried about their girl Frlends (77.6): anothex twelve worpled about their wives 873.7 ). (It may be pertinent to repeat that only nine men were living with their wives athough 26 were legaliy markied.) Parents were a source of worry for 20 men but recelved a mean intensity of 69.0 .

Although 19 assigned the blame for thelr trouble with the l.aw to such factors as associates, and 24 to thelr past record; 31 answered that the reason was that they drank too mueh, and 16 replied that it was their own ant-social behavior. 
Thirty-seven of the men felt they had recelved a fair deal when they were arrested and sentenced. of the 21 who answered no to this question, all thought the sentence was too heavy and 11 said they were unfustly convicted. There was overlap in the responses with few respondents thinking they got a falr deal but the sentence was too heavy. No efforts were made to clarlfy these differences.

Inmate Feelings about M.C.C.I.

In an effort at finding both positive and negative Inmate feelings regarding M.C.C.I. two questions calling for a spontaneous answer were in the questionnalre. Things that bothered the inmates received an intensity mean of 60.2. The specifics given most often were later categorized as incarceration, and Included "belng locked up", "loss of freedom", etc. although my qualified this answer by saying this was better than any other detention facility. Nine men disliked authority in general, nine disiked the other inmates, and eight disliked the lack of rehabilitation. What they I1ked about M.C.C.I. recelved an intensity mean of 86.2 indicating a positive attitude towards the institution. Specifics mentioned most often were the genexal institution (30); Preedom to move around (16); recreation program (16); and food (13).

The visiting privileges recelved a favorable intensity mean of 88.4 , from 51 inmates. E1ght Inmates were 
dissatisfied with the visiting situation, with a mean intensity of 37.5 .

Fifty of the men gave a positive intensity mean of 96.9 to the mail privileges; nine men were dissatisfled to an intensity mean of 43.9 . Comments from the latter were to the effect that censorship of mail was not in keeping with the honor system of the institution.

The recreation program recelved an intensity mean of 79.9 In Inmate answers which is also a positive response. However, one older inmate sa1d, "Them athaletes (sic) is always thumping around."

Hany of the inmates remarked upon the generai attitude of the staff and the helpfulness of some individual staff members. One endorsement given was. "You wouldn't evern know some of 'em was cops."

Post-Release Plans

Within the limitations of an imperfect questionnalre and a stringent time schedule, the ummet needs of the inmate population of M.C.C.I. have been delineated. The hypothesis that these needs fall within the areas of human need served by sociai work agencies and commun1ty institutions has been supported. The question now arises, where will this population go upon release? W1th whom w1ll they live? How long can they stay? What communities will they be living in? Twenty-two men w131 live alone; 17 with parents; 
nine with a wife; elght with a relative; and three with "other".

Whether they will live alone or with someone the population indicated they can stay: indefinitely (46), less than one month (5), less than six months (2), less than one year (1), and don't know (5).

Forty men (68\%) will return to live in Wultnomah County; nine men (15\%) expect to live in Oregon, the majorIty in Washington or Clackamas Counties; eight (14\%) were going out-of-state, at least two because they could obtain a driver's license; and two did not know where they would go, meaning with reference to needs.

To recapitulate, the unmet needs of the inmate population of M.C.C.I. have been dichotomized into post-release needs of immediate urgency, and long-range needs seen as necessary for future functioning in a more adequate manner. The descriptive findings of this study show that the population of 59 men recognized a variety of interpelated needs, of varied mean intensities and oxtensities. Responses showed total of 102 post-release needs and 320 long-range needs.

Two needs indicated by the majority of the respondents were for a job and/or money.

Post-release needs have been ranked by the mean extensity of need. Data on inmate self-concept, affectional t1es, and group membership by cholce, have been evaluated. 
Destination of inmates upon release, as well as potential Ilving racilites have been cited. 


\section{CHAPTER VII}

\section{FINDINGS: INRERENTIAL}

In addition to the core questions regarding extensity and Intensity of need, other questions relating to reed were posed throughout the questionnaire. Inferences may be drawn by comparing various answers, grouped under the five headlings of universal needs.

These five areas of need are:

1. Physical needs: Food, clothing, shelter, medical care.

2. Soclal Needs: Interpersonal relationsh1ps, group affiliation by cholce, religlous, and recreational.

3. Psychological needs: Self-concept, w1llingness to accept help, desire for change.

4. Educational needs: Vocationa 1 and academic tralning.

5. Financlal needs: Post-release funds, debts, employment.

These areas w111 be considered separately, with some of the inferences phich may be drawn from the data.

Physical Needs

Inmediately following their release, 12 men will need lodging and 17 will need clothing. Physlcal needs for the future include 26 men needing housing, 22 men needing clothlng, and 22 men needing medical care.

Food was not mentioned as a need. However, money and job (covered under financial need) were cited as 
post-release needs by 20 and 22 inmates respectively. Possibly food is a primary reason for the need of a job or money; the soup kitchens are avaliable if money or job are not. For these two reasons, food is not seen as need by the Inmate population.

We must also consider the obvious possiblit.ty that, should the soup kitchens close down, minor offense may be conmitted resulting in incarceration.

When specifically asked how their health was, six answered poor and no one sald very poor. Thirteen ilsted specific hesith problems. The remalning 53 all sald their health was good or very good. However, 22 men c1ted the need for medical care and 1 tranked sixth in extensity. A more rellable agreement appears in the need for housing. Twenty-six men indicated this as a need. When asked in another question with whom they would live upon release, 22 expected to live alone and an additional five indicated they could stay less than one month at their anticipated shared housing.

Soc10.1 Needs

Interpersonal relationships and group affillation by cholce have been discussed at some length in the chapter on descriptive flindings.

S1xteen men responded to the recreational need category. giving this a mean extensity of 53.7 and a mean 
intensity of 60.0 .

Thirteen men indicated a religious need, giving this a mean extensity of 51.2 and a mean intensity of 55.4 In another question, 14 men knew a priest or minister to whom they could turn. The 59 inmates gave a mean intensity of 36.1 to the question: How helpful do you think the church could be?

It was assumed that social interaction was a basic human need but the inmate population does not indicate that they have major unmet soc1al needs. However, the minor number of friends, of group affiliation by cholce, and of urmet needs shown in this area may be due to several possibilities:

1. This may not be a basic human need.

2. Iimftations of the questionnalre in delineating their social interaction. These needs may be met in a deviant manner which was not disclosed.

3. This may be denial of need as a defense of self: Psychological Needs

Self-concept has been discussed at length in descrip. tive Iindings.

As positive qualities, 44 of the inmates thought they were good at physical skills, 30 thought their moral qualities were good, 29 men clted personality, 28 sald mental. ablilties and 27 said leadership.

When listing problems that bothered them most about 
themselves, 20 innates each cited self-consciousness, aggressiveness, and lack of self-confldence. Nine each stated they were bothered by irresponsibility or impulsive behavior.

Thirty-seven said a better understanding of themselves would help them stay out of trouble and other factors mentioned were staylng away from alcohol, and holding a job.

These problem areas are dealt with by soclal work agencles whose runction it is to ald Individuals with "a personal or family problem." Agencles 11sted in where to Turn are categorized under the area of need which they serve.

The inmate was asked if he knew of an agency that could help with his particular type of problem. Seventeen replied in the affirmative; 42 did not know of any such ageney. However, 35 indleated they had recelved agency help in the past. This discrepancy may be interpreted in two ways: (1) previous agency contact was not seen as helpful or relevant to the current particular need; and/or (2) no agency was known to help inmates whose need related to such an area as a driver ${ }^{\circ}$ icense.

When asked "If you knew of such an agency would you txy 1t?" replies were: Twelve, yes; s1x, maybe; and 41 , no. Oit the basts of these repiles the conclusion reached is that 70 of the men would not use an agency for the currerst 
problem if they knew of one.

A list of places to turn to for help would not be ut1lized to a great extent. Inmate 1deas as to what type of list might be helpful to chem included sixteen suggestions for soclal agency referral (AA, Mental Health, Family Centers, YMCA, Halfway House), and Individual counseling; eleven for employment information; and five for legal, financial, or pre-release information.

If outside speakers come to the institution, topics the Inmates would like to hear about included: Job and employment (29); counselling (21); and general non-personal toples (11). However, eleven men were not interested enough to suggest a topic and the mean response to the question on having outside speakers was 51.3 for the population as a whole.

These men see some of thelr dysfunctional attributes but the desire for change is questionable. Motivation to accept or to seek help appears to be low, although psychologleal needs are shown by the daca. Mean flgures may obscure willingness to accept help because of the age range of the population.

Therefore several scattergrams were drawn to find potential patterns of distribution. Sone of the results have been mentioned previously, such as the age and charge distribution.

The modal, 180 day sentence was recelved by men in 
a11 of the three age categorles of Chart 1. (Appendix)

It is of interest to note that this sentence was also received In all of the offense categorles listed in Chart 4. As has been previously noted, the driving offenses cluster around the under-25 age quadrant. A scattergram for age and the question "How much does being in trouble with the lan bother you?" reveals a cluster of the under25 aged inmates in the highly-welghted intensity quadrant (75 - 200). A Ch1-square employing the median age (24) and the median score (75) as axes gave the following results:

$$
x^{2}=6.24 \quad \text { d.f. } \quad 1 \quad .01<p<.02
$$

There is, therefore, a significant difference the .02 level between those above and those below the median age Who are bothered more than 75 on a hundred polnt scale by "being in trouble with the law". These younger men are bothered more by trouble with the law than are the oldex men.

A scattergram was drawn for age and the question "If you knew of an agency which could help with your particular type of problem would you use 1t?" This question called for yes, no, or maybe answer. A cluster in the no/under 25 quadrant suggested further testing. The relationship between the "no" answers, and below median age group gave the following result in a Ch1-square:

$$
x^{2}=13.08 \text { d.f. }=1 \quad p<.001
$$


There is a signifleant difference at the .001 level, which raises the question of how one can effectively work with this age group (under 25), many of whom are in ja11 for driving offenses. The assuraption of a high intensity of "bother" in any particular instance as indicative of potential effort to change is not necessar11y disproved, but the under-25 age inmates do not see a social work ageney as the vehicle for such potential change.

Educationa 1 Needs

Education was seen as a need by 30 Inmates with an extensity of 72.3 and an intensity of 77.2 . Fifty men indicated elsewhere in the questionnalre that additional education or training would help him (mean extensity 74.1)。 Education be seen as helpful, particularly in view of current emphasis on education, without being seen as a need by the individue 1 . Older Inmates and those with less than an elghth grade eduction were realistic in saying they could not make it in schools todsy, or it would require too wuch time needed for work. Therefore 1 esmot be assumed that Inereased motivation would enable this adalional 20 men to see additional education as a need. However, to augment their economic Iunctioning they might be accepting of practical on the job treining of short duration. 
Financial Needs

The Immediate necessity of money upon release has been discussed in the previous chapter, as has the need for a job as a long-range need of the highest order. Another question regarding future plans asked if the inmate had a job to go to. Twenty of the men answered yes; 23 sald no; and 16 sald maybe. Even though only 23 were definitely without a job to go to, 42 of the 59 respondents $(71 \%)$ said that job was a need. Some interpreted this question to mean need for a better job than the one to which they were returning. However, 31 inmates indicated they had trouble in the past either in getting or holding a job so this could be a recurrent need.

Almost half (28) of the men replied that they had trouble with money in the past, indicating that this may de a constant or a recurrent need. However, in the subcategory of debts, consideration should be given to inmate attitudes regarding specifies such as fine, garnishment, and amount of money owed. These three items were within the lower half of unmet needs in extensity and intensity.

The evidence of these answers is that the men sat the need for a fob and money as beling highest on the list of unnet needs but the obligation to sectle finselal obligain tions low. 
Statistical Analysis of Job Needs

Inasmuch as employment and money appear as constant or recurrent needs in the inmate population, the need for a job was analyzed in considerable depth. Statistical analysis was also required to validate the findings which have been described herein.

The research hypothesis suggested that there would be no difference between interviewers in the research group and that they would not attribute to the men profections from their own midale class, or other biases.

Training sessions, pretests and an objective schedule were alds towards objectivity. In addition, analysis of variance and supporting tests were used to test the null hypothesis of no differences anong interviewers and/or inmates.

Since this question was a key one, it was chosen for detalled study. An $F$ of inmate and intervlewer variances showed no significant difference.

$$
\mathbf{P}=1.28(36,5) \quad \mathrm{p}>.05
$$

The probability of different means and different variability is rejected by this and other tests. The probsbility of the same means and varlablilties is highly likely, wth considerable of the variability due to chance, most due to actual variation among the inmates, and least due to interviewer differences, as w11 be seen below. By inspection 
and the above observations it seemed clearly improbable that there were difrerent means and the same variability.

The restaual varlance was large $(2,852.25)$. LResidual varlance represents the difference between the total sum of squares $(10,005.6)$ and the sum of between-interview squares, plus within-group squares $(7.153 .35) .7$ Thts is considerable unexplatned varlance and an attempt was made to account for 1t. By inspection, there appeared to be considerable variation in the range of scores and in the intervlewers" recording high intensity scores for this question. In order for the reader to follow the reasonIng more closely, answers to question 41 appear in Chart 12.

The total mean welght of 92.8 on a hundred point scale, with a total standard deviation of 15.6 and a range of 20 to 100 , indicate that this is not a normal distribution but is heavily skewed to the left.

The standard devlations for individual interviewers show a wide spread, but only one 18 more than two standard deviations from the mean, and another 1 s between one and two standard deviations from the mean. Inasmuch as these were the two men in the research group, it was felt that immates might not have been as open and free with responses to them as to the women intervlewers. It was also believed possible that men interviewers might have; by chance, interviewed fewer married men. The assumption behind this was 
that married men, even if divoreed or separated, would feel greater need for a job because of family responsibil.o ities.

To test this possibility, a Chi-square test was done on the number of responses recelved from marled versus never-married men, as given to men versus women intervlewers. The result of this test was:

$$
\mathrm{x}^{2}=0.007 \quad \mathrm{~d}_{0} \mathrm{f}_{\mathrm{f}}=1 \quad \text { p }>.95
$$

This is not a significant difference and supports a null hypothesis that there is no difference between the distribution of married/never married inmates to men/women inter viewers.

The number of responses per interviewer was examined. It was noted that two of the three interviewers who listed seven or more Inmates with a need for a job welghted these as a tots 3 need, or 100 . The question arose as to whether those intervlewers finding more job need in their samples were interpreting this need differentiy from those not encountering this need so frequently.

At this point it should be stated that many inmates had difficulty in giving their answers a numerical welght on hundred point seale. It was necessary both to lead and interpret answers for these men although no figure was recorded without their verification.

A Chi-square to test differences in the weight given ("100" or "under 100") and the number of responses recelved 
("under 7" or "7 or more") gave the following result:

$$
x^{2}=5.49 \quad \text { d. } 0=1 \quad .01<p<.02
$$

A null hypotheses that there is no difference between the weight given a reply and those interviewers obtaining seven or more responses, as contrasted with those interviewers obtalning less than seven replies, was not supported. There was significant difference among the observers associated with estimations of the seriousness of this problem. This significant difference was obscured in the andysis of varlance because the variances were unequally distributed. We must, therefore, assume that the residual variance was due in part to differences among interviewers in their estimation of seriousness and in part to unknown factors. The interviewers were asked how they interpreted the inmates" responses. No inconsisteney in logic, nor in reasonable assumptions or criterion could be found. Differences could plausibly be attributed to differences among the Inmates and not to the interviewer bias.

The possiblilty of inmate irresponsibility could not be overlooked. For instance, question \#13 askis if the inmate has a job to go to on his release. Interviewer 2 had replies of eight no, and two maybe, so the nine answers (on 41.) welghted at 200 appear val1d. Interviewer 4, had rive men answer yes, three maybe, and two no, so the nine answers welghted at 100 appear unrealistic. Interviewer 6 had nine men reply no to question 仕13, yet only four answers 
ranging from 50 to 90 weight. As noted above, these last two inconsistencles may be due to inmate irresponsibility, to interviewer differences, or to difficulties in discrimination. It is undoubtedly easier to decide between yes and no than it is to make the finer discrimination from a range of 0 to 100.

Sunumary

The mean weighted values and the range of unnet post-release and long-range needs of the inmate population of M.C.C.I. are given in full in Appendix B, in addition to a summary of answers to the complete questionnaire. This complete data is 1ncluded for the reader who may be interested in answers not analyzed or compared in this chapter.

Many more questions were asked than have been commented on or analyzed. Time I1mitations necessitated confining attention to those questions deemed most pertinent. Some of the questions were asked in the search for repport with the individual and though not pertinent to the focus of this study may of interest to ochers.

The for hypothesis of inmates having unnet needs was supported by inspection.

The major hypothesds of no difference among 1ntervlewers or inmetes reporting the needs was supported by andysis of variance. The sub-hypothesis of no difference 
among Interviewers in recording intensity of need was not supported by Ch1-square.

The fact that only answers to the need for a job were covered in the statist1cal analysis for validity of the study may be a limitation. This may not be true of other indings but there do not appear to be significant differences from other needs, which were c1ted by fewer respondents. 


\section{EVALUATION AND IMPLLICATIONS}

The major hypothes1s states that jall 1nmates, during incarceration and upon rease from the institution of confinement, have unmet needs which could be setisfied through adequate social work services.

Conduct of the project involved six graduate students who interviewed 59 inmates at M.C.C.I. by use of an administered questionnalre which consisted of 73 scheduled and open-ended questions.

This chapter ill discuss the values and limitations of the study, possible pelationships between the lindings and the literature and Implications as they relate to the practice of soc12l work.

Critique of the Questionnale

General reactions to the questionnalre as a tool in the hands of the interviewers showed that certain modiflca tlons were indicated. The ambigulty of sane questions was puzzling to the Inmates. Some questions were complicated and unwleldy; others were somewhat threatening and tended to put the men on the defensive. Everyday matters pertaining to job, education and the like should have come flust in the series of questions.

Certain questions were so compat as to be overlosded, whlle others, minute and detalled, could have been combined 
more economically. There were several near-synonymous questions, the wording of which did not differ significantly from others. However, these were useful as a crude test of reliability. In some, phrasing and sentence structure were faulty and contributed to the confusion of those interviewed.

Scaling. In reviewing administration of the questionnalre, it was found that the requirement that a value on a hundred-point scale be assigned to answers was a difflcult expectation and resulted in somewhat arbitrary response in some instances. In general, the instrument was seen as highly time-consuming because of the need for frequent explanations before the men could comprehend the meanings of some questions.

Pre-test. The questionneire in general was diff1cult in portions because of the arbitrary function of assigning answers on a hundred-point scale. Due to time limits, only one pretest was done and after that inftial testing, considerable alteration and adjustment was effected on the questionnaire. More pretests would have been helpful, particularly if there had been sufficient time allotted to afford ample discussion and analysis of meanings. Thls kind of prior knowledge and facility in handling the tool would have maximized the efflclency of the questionnaire. Added training of those administering the questionnalre before the pre-test could have been intensifled and 
followed up by discussion and suggestions. It was felt by some that elicitation of responses would have been more easliy achleved if several pre-test interviews had been conducted. There were only two training sessions.

A number of offenses Involved alcoholics. In the main there was consensus that experience proves that alcoholles are not generally disposed to rolce special needs so long as board and room are currently adequate. Indigenous in the alcoholic syndrome is the dependent position which is enjoyed even in M.C.C.I. Therefore, this fact could have introduced a disavowal in their folt needs or increased their dependency on the institution for needsatisfaction.

Researcher's Evaluation. Ech member of the research project was asked to make critique of the questionnalre after completion of all interviewing. A summary of these responses was revealing. It was surprising that among six interviewers there was relative consensus regaxding the usefulness of the total 73 questions, with only minor variations and differences of opinion regardIng some of these questions. Elght questions were serlously criticized by all researchers. Question 4 -- How close are your family connections? Interviewers found this question to be ambiguous and vague. The question was intended to get at the closeness of relationshlp between the man and his immediate or 
nuclear family. The inmate found this difficult to answex because he was often close to h1s chlidren but resented his wife, and vice versa, or close to his mother but resistant to his father. How should the question be asked? "How would you describe the relationship which existed between you and other nembers of the family?", with answers 1tem1zed.

Question 7 -- How much of a shock was all this to those who kmow you?

Th1s question was regarded as too general. The word "shock" and the phrase, "to those who know you" ellc1ted many questions from the men and required much explanation from the interviewers. A better construction would read: "How do you think your family and frlends feel about your being here?" Question 25 -- Who 18 lesst helpful to you?

Implicit in this question is a negative response and consequentiy it appeared threatening to the men. They appeared to be defensive and found difficulty in answering. We also questioned the usefulness of this question to the study. Because the results were so widely diversifled, there was no andysis of the findings. Question 26 -. How easy has it been to get the help you ore your family needs?

This question showed some inconsistency in recording. The other scales in the questionnalre ran from "easy" to "difflcult", but this one ranged from "difficult" to "easy". 
In addition to being awkward in structure, this question was repetitious, too complex, and not limsted to any specific period of the man's 11fe. The general response from the men to this question was that they were not quite sure what was being asked. Question 53 -- What do you need to put this plan through? When seen in context w1th the two questions Immed1ately preceding 1t, this question has a faulty referent. The question was posed in an effort to get at the particular program or tangible help that would facilitate the response in the previous question, "What plans do you have?" If there were a negative reply in Question 51, (Do you often think additional educetion or training would help you? a. How much?) then, Question 52, (What plans do you have?) and 53 (above) would not be applicable. Possibly. these three questions should have been combined. Question 60 .- In what areas does 1 t bother you?

In administering this question the interviewer had to explain the relationship between it and the previous question. It was necessary to explain the word "areas" as relating to the particular ways in which being in trouble with the law affected them. For example: "Would it affect your family relationshlp?", or, "Would it affect your employment opportunities?".

Question 67 -- What do you think you are good at?

There was unanimous agreement that this question 
combined acquired skilis with character traits and moral attributes, thus confusing two 1ssues. It was somewhat awhord and unwleldy and could have been more productive were 1t asked differentiy. Furthermore, the areas in which the men were required to indicate their skilis and proficlencles were in some instances beyond their intellectual grasp as constderable explanation was required. However, this question also placed the men in an ego-strengthening position and afforded them some pride in being able to say, "I am good at..."

Question 69 -.. What do you think needs to be strengthened so you' 11 get along better outside of here?

This question very nearly duplicated parts of Question 61, and therefore could have been combined. However, 1t wes found that answers to Question 69 usually referred to areas of self-concept whereas referents in Question 61 embraced self-concept and soc12 1 or communtty resources. Question 71 ... Would you word some of these questions differentiy?

Question 72 - Hould you use other types of questions? a. Suggestions not covered?

Question 73 -- Do you have any other questions or suggestions about this study?

These quastions were designed to provide the inmates with an opportunity to voice their general reactions and contribute to the questionalye and the interviewing process In genera1. Approximately 30 per cent of the men did not 
have any criticism or suggestions. They felt that the quest1onna1re "covered everything", or "was pretty good", or "I couldn't do better", or "No, I don"t have anything to add." Most of the remaining 20 per cent of the men used this time to ventilate feelings about something which was not pertinent to the questions asked. The responses of the remaining men are recorded below:

"Some words are too big and difficult to understand." "Study is fine, but I need something to help me right now."

The questions are all different but they are too much alike."

The information gained from this section was not significant in terms of usefulness to this study. However, the Inclusion of these questions was seen as appropriate because they did give the men opportunity to express their feelings.

Relationship to the Iiterature

There are recognized relationships botween the ilterature and the findings as they concern needs. R. $q_{0}$. Andry stated that the need for satisfaction and reward through meaningful work 13 to be met by rocational training and gutdance; the need for mutuliy effective and gratifying Inter-personal relationships is to be handied with the experience of working with other people (teamwork, group 
work); the need to recognize and develop a sense of responsibility is to be handled through payment of fines coupled with the jail sentence; and the need for pleasure is to be accomplished through leisure time activity and accupational therapy. These needs were advanced in a study of paroled short-term offenders in England and correlated with those specifled as the Ilve major areas of th1s study in Chapter $V$.

Joseph R. Silver advised that the obvious problems of Inmates fall Into the category of "concrete needs", a term that seems more appropriate, descriptively, than "physical" needs as used in the project formulation. Elmer W. Olsen differentlated between needs as recognized by the staff of the institution and the parolees; the latter being designated as "elemental felt needs", which correspond readily with those mentioned in this study.

This study was concerned with unmet needs which might be alleviated, at least to a degree, by referral to social work agencies and communty institutions. Treger, using need as a baste premise, discussed the problems facing the social work fleld in 1 ts efforts to work with offenders. Studt, in her writings, used social work principles to formulate a structure of professionalism geared toward correctional services. She outlined needed skilis and knowledge required for other divisions of sceis I service. Although the ilterature review revealed some 
negative feelings toward use of this discipline in relation to treatment and rehabilitation, there also was recognition that the fleld of soclal work already was involved in areas of corrections and could become an effective resource for use by correctional institutions, particularly at the time of release and/or parole of the inmate. Carle F. O'Neil supported this Idea.

Projections from the Literature. Review of the 11terature showed a dearth of information pertinent to commun Ity resources directiy related to corrections and the shortterm offendex. However, it is possible to make a rough projection showing the feaslbility of greater involvement and communication by local public and private agencles. If a typology or similar classification scheme could be developed around the concept of Inmate need, then w1th some training, referrals could be made by workers in the correctional agencles to appropriate public and private agencles for follow-up care at time of release, particularly where social work service might make the difference between a patiern of recidivism or a readjustment to social. norms.

Public Agencies. The Public Welfare Department in Oregon, upon officlal request, writes social history on the family backgrounds of inmates for state correctional institutions. Caseworkers srequently have the families of inmates in their caseloads during the period of incarceration. 
Sometimes the released prisoner, if there is physical or emotional incapacity, is eligible for public assistance.

In counties less complex than Multnomah, there is frequent contact by ja11 officlals and the office of the district attorney on case situations. Multnomah County has been assigned a special branch of the State Attorney General's Office known as Welrare Recovery Division (WRD). This office manages legal matters of the County Welfare Department in 1 ts relationship with clients and is the coordinating agency between the Welfare Department and jail official.

The Social Security Act of 1962, encouraged public welfare agencles to broaden the scope and quality of services to clients. The emphasis of thls act was on the meeting of needs through intensive service caseloads which are small enough to enable the worker to give adequate counselling, planning and service. In addition, public welfare was involved in work-training and educational programs through cooperative planning with the employment service and other programs of this nature. Thus, it is geared to handle the concrete need of employment and training.

The California Department of Public Weltare has demonstrated keen interest in resolving the problems of inter-agency involvement in cases where the parents of chlldren supported by Ald to Pamilies with Dependent 
Children are in State correctional institutions. This department has supported a number of pllot projects culminating in an inter-departmental guide setting forth state policy and procedure for the sharing of information among county welfare departments, state correctional institutions, and state perole and probation offices.

Review of communtty social service resources with an Idea of 1dentifying and broadening existing programs to Include spectalized services for released short-term prisoners, as stated in the initial planning of the project, was not feastible in this study. A depth research would have been required which could specifically study institutions and agencies to determine what aspects of planning they could provide with their service. Two studies pertinent to sarvices provided by social agencies were reviewed in Chapter IV -. the Report of the Priorities Comittee of the Portland Community Counc1l, and Recommendations made to the State Board of Control by the Oregon Council on Crime and Delinquency. Pertinent sections of the former study 111 be discussed In Chapter IX.

Implications Warranted from Data

Findings of this study indicate that inmates have needs which could be met by existing soclel work agencies. The needs, which span a wide area of personal and social we11-being, seem to cluster around those needs designated 
as economic, namely job and money.

However, it appears that the inmate, upon release, would be unlikely to make voluntary contact with social agencies that could directly or indirectly provide for his needs. This conclusion appears warranted by virtue of their responses to question 48:

Do you know of an agency which could help you with your type of problem?

a. Will you use it when you get out?

Forty-two men did not know of such an sgency; fortyone men would not use it, even if they knew of 1 ts existence.

The men seemed to be responsive to receiving information if they did not have to take the initiative. On the hundred point scale, interest of the total inmate population in having speakers from the outside was 51.3. Areas of interest included jobs and employment, 29 men; counselling, 21 men; and general topics, 11 men.

The conclusion drawn from the above paragraph would Indicate the strong possibility that a professional worker (social worker) at M.C.C.I. coula be functional with rehabilitation of the inmate population. By his professional relationship and service to the inmate, the worker might serve not only as a motivating influence, but also as a broldge between the 1nmate and the communtty agencies providing for those needs.

The age group embracing inmates twenty-rive years 
of age and under accounted for the major portion of the driving and larceny offenses. This age group also showed the highest degree of concern for being in trouble with the law and the least motivation for seeking help. Hence, such a combination of factors would indicate that prior counseling could be of value both to the inmate and the general community which shoulders the burden of financial responsibility for incarcerated men. Samuel Mencher discussed the place of early intervention. He stated, "A social service is most effective and least costly when the problem it is designed to meet... Is dealt with as quickly as possible after it arises." $\bar{D} .77$

Economic Needs. The immediate needs at release of the average Inmate M.C.C.I. were not as pressing as his future needs. The zeason was that the inmate's earnings, 25 cents per day, were deposited in his account until the day of his release. With a sentence of 180 days as the mode, and an average work week of flve days, the average inmate leaves H.C.C.I. WIth $\$ 32.50$. However, if an inmate had to provide for his basic needs such as street clothes, transportation, room and board, in a very short time his rinances would be depleted. Such minimal funds indicate the urgency for early job procurement. Counseling to stimulate effort, to extend support and encouragement during this period (post-release and job finding) would be a positive help. This picture is a reflection of the general condition 
throughout the country, but in Hultnomah County conditions are little above average.

In answering the question, "how much money do prisoners get on release?", Lols Wille studied four types of economic assistance systems. These systems were cash gratuitles or "gate money", earnings while in prison, loans given by the state to released prisoners, and losn funds from private agencles. The gate money most commonly pald to released prisoners ranged from a high of $\$ 50$ to nothing. The low rate of pay (sometimes as low as 4 cents a day) IImits the amount of money a prisoner can earn during his incarceration.

Increased economic assistance to released prisoners-whether in the form of unemployment benerits, loans, 1ncreased opportunity to earn while in prison or superior job training -- does not mean that counselling will become unnecessary 。

To facilitate post-release difficulties, pre-release arrangements are recommended. Possibly, the men could be given time out of the institution, prior to release, to actively seek employment and make arrangements for adequate housing. A social worker or other professlonal personnel famillar with the community and environmental resources could be of invaluable assistance during this phase. Another possibility that could amellorate post-release difficulties is that of establishing ar infomation bureau 
or job placement office at M.C.C.I. The administration of this center could be included in the portfolio of the ja1l counsellor or social worker. Some weeks prior to his release, an inmate would indicate to the counselior the time of $\mathrm{h} 1 \mathrm{~s}$ release, the type of occupation desired and other pertinent information relative to job placement. The worker, who would be in dally contact with the Employment Bureau and other agencles engaged in job placement, could have a position for the inmate immediately upon release or could offer him some definite leads. In addition to job placement, thls worker could offer counselilng and suggestions on all that is involved in finding job.

Soc1al Needs. The establishment of a down-town center would appear helpful. This could be a type of a half-way house where men could receive telephone messages regarding potential employment, have a cup of coffee, and talk with other men in quiet surroundings. In establishing such a center, careful consideration should be given to the name. A name that constantiy reminds the community of ex-prisoners within their midst could reinforce the existing negative public attitude toward the man with a "xecord" 。

Efforts should be made also to diversify the population by encouraging men who have not been Incarcerated to participate in 1 ts social program. This would tend to reduce the propensity of the public to label the men who 
v1sit as ex-inmates. Constant evaluation would be needed to guard against deterioration into soup lines and flop houses.

Summary

Chapter VIII discussed the values and limitations, relationships between the findings and the literature, and Implications drawn from the data. In general, the question. nalre was seen as useful research tool for gathering data. However, several modifications were recommended for its improvement. The over-all response of the prisoners to the questionnalre was favorable.

The work of Andry, Silver, and Olson had particular significence for this study. Projection from the literature Indicated that public and voluntary agencies can and should become more involved with treatment of the released misdemeanant of fender.

Implications favored the use of social workers within the institution itself, the establishment of a jobplacement office, and the creation of a down-town social. center。

NOTE TO CHAPTER VIII

1. Hille, Lois, "Miney Against Crime", Pederal Probation, Vo1. XXVI, No. 4, Dec. 1962, pp. 34-38. 
CHAPTER IX

SUMPARY AND SUGGESTIONS FOR FUTURE STUDIES

In this concluding chapter, a summary of the study w11l be given along with suggestions for ruture studies.

This research project was undertaken as a descriptive and exploratory study. The primary goal was to determine the kinds, irequency, and intensity of needs confronting varlous types of prisoners upon their release from the correctional institution. The population consisted of 60 Inmates of the Multnomah County Correctional Institution. An open-ended questionnalre of 73 questions was administered on an Individual basis omphasizing needs in economic, social, personal, and family areas. The verbal responses of the men, which were recorded by the Intervlewer, provided the data for the study. Validity or rellability of responses not questioned. Confldential face sheet information from the files, however, did support some of the responses of the men. Statistical analyses were made whenever possible to determine correlation between seis of information.

The results showed that there was a signiflcant percentage of men who had post-release needs, espocially in the area of economic security - - job and money..

Some of the inmates Indicated various ways of meeting their needs, but a small percentage of men in the sample had no ways or Ideas by which these needs would be met, 
Although a comprehensive study of agencies was not undertaken, a limited investigation of social agencies polnted to a minimum of agencies offering post-release services for misdemeanant offenders. The services were inadequate to meet the wide range of needs. This fact was a Iso indicated from the Report of the Priorities Committee, Which was mentioned earlier in this study. By observation, there were no significant variations between extensity and intensity of needs as cited by the older and younger members of the population. However, there was a significant difference in their attitude toward the acceptance and use of help. Young inmates typlcally reported that they would not avall themselves of the services of social agencles even if the services were provided.

The profession of social work has defined the fleld of corrections as an appropriate setting for the practice of social work. The profession has a body of knowledge Including sk111s, understanding, and techniques necessary in the therapeutic milieu of the offender. These professionel skilis and techniques must be employed in several areas, namely, administration, inter-agency relationship, Individual, group and community. The generic aspects of social work recognize the needs of the offender in the institutional setting as well as in the community. 
Recommendations for Future Research and Action

In conducting a study of this nature, numierous questions, Ideas and speculations arise. In addition to Its own conclusions, this, as other studies, has opened up new areas of Investigetion. Some of these new areas warrant closer scrutiny by future researchers.

One of the findings indicated that between $68 \%$ and $83 \%$ of the Inmates w111 continue to reside in Hultnomah County and the surrounding area upon the1r release from M.C.C.I. The sum of their unmet needs 111 go with them from the institution into the C1ty of Portland and 1 ts environs. This belng so, there is an indicated need not only for reassessing the soctal agencies which could provide services and practical help, but also there is a need to make these services easily accessible to the men.

A suggested project would involve a depth study of the existing soclal agencles in the greater Portland area (both those now providing services to inmates and those that are not) to determine to what extent they are equipped and wlling to respond to the needs of released prisoner"s. Such a study would be similar to the 1962 "Report of the Priorities Committee, but the emphasis woula be specific11y geared toward the needs of prisoners. Report of the Priorities Committee. In 1962, the Portland Community Counc1l made fortat study of the 
Tri-County (Multnomah, Clackamas and Washington) Community Services in relation to the community needs. The results of this study was published under the caption, Report of the Priorities Committee, Portland, Oregon, 1962. Fiftyfour flelds of services were identified, defined and classifled.

Each service was analyzed in terms of three interrelated, yet separate, criteria:

1) Considerations of desirability, importance, and effectiveness.

2) The degree of unmet community needs.

3) Considerations of financing.

The Priorities Compttee found the "Service of Correctional Inst1tutions for Adults" to be in the rank of third communtty need category.

"While the cost of criminal activity is constantly rising, correctional institutions are positioned in the third community need eategory because they protect the community only briefly (95\% of aduits committed to institutions return to the community) and do not serve well to rehabilitate individuals. (There is a recidivism rate of approximately $45 \%$ nationaliy.) Probation service at the court level for $70 \%$ or $80 \%$ of first of fenders would be a much less expensive and more effective rehabliltative and protective mea sure.

"Correctiona I Institutions in Oregon are considered to have good standards of cleanliness and care, to provide sufficlent vocational activity to keep prisoners occupled and to deal in a humane manner with them. Parole supervision is suppiled to only $44 \%$ as contrasted with $99 \%$ in washington and $87 \%$ in California, thereby depriving the released prisoner of crucial assistance in becoming established in the community as a law 
ablding citizen and adding greatly to costs by having to be recommitted when new offenses occur. More institutional expansion should be avolded and investment made in full time parole board and professional starf, a service much less expensive and more effective than institutionglization. (2)

In interpreting the material from the Priorities

Report, it should be remembered that the priority plan was based on Identiflable flelds of service offered by the community and not on the needs of the individual. It is possible that the needs of the individual and the needs provided by "flelds of service", are polar, and as such, are unrelated. Community services should be geared to meet identifled needs and not merely to provide service per se.

Another section of the Priorlties Report that has relevance to this study was the "Assistance to Single Mnployabie Men". (3) This service provides financial assistance to employable men who are temporarily in need of the basic necessities of life (food, shelcer, clothing). Nine agencles were 11sted, three public and s1x private, as offering services.

Although this service was positioned in the third community need category, there was only 25 per cent capab11ity of neeting needs. The report stated that:

\footnotetext{
"The single employable man has generaily been excluded from eliglbility from public welfare asslstance even though it has long been established that other methods of dealing wh this particular group (soup lines, flop houses, etc..) are debliltating to the
} 
personality and only compound the problems of the single man.

"Estimates of the number involved are less than 500. A local survey revealed that on a sampling basis almost forty (40) per cent of the men had been in Oregon over three years. Many are regularly employed in seasonal agriculture and are needed then.

"As with many prograns of financial assistance, this should be only means to an end. Because the single employable man presents many complex problems which are often difficult or impossible to solve based on our present knowledge, this service should relate to other programs which attempt to treat the disorders making for financial dependency." (4)

This source was cited not only because it offered a possible avenue of meeting needs of released prisoners. but also to point out the inadequacy of services offered single unemployed men. Wny prisoners, upon release, fall into the category of single employable men in need of the basic necessities of IIfe.

In the rirst chapter, readers were cautioned about sweeping generalizations. However, in spite of the screenIng process and the psychological testings which influenced the transfer of the Rocky Butte prisoner to M.C.C.I.g there is the possibility that the needs of the prisoners at Rocky Butte and prisoners all around this state are not dissimilar to those 1dentifled at M.C.C.I. Therefore, a researech design could be drawn up to determine to what extent the needs of prisoners are similar or dissimilar from one institution to the next. Could a social agency 
that is currentiy engaged in a treatment program expand its service to include other institutions with similar inmete needs?

In presenting their report, the Priorities Committee felt that:

"New services and new methods...
do not necessarily require new agencies.
In fact, existing agencies need to be
constantly examining their efforts to
discover new and better ways to provide
needed services and to accomplish better
results
sary services shor obsolescent or unneces-
bility of each existing community sesponsi-
and of those which might be established in
the future." (5)

Determining Family Meed. Because of their incarceration, some men were unable to provide for their famm 11 les and dependents. It is not known to what degree or how dequately familles and dependents were provided for prior to incarceration. However, the fact of incarceration has created definite family needs. A suggested study is that of determining the real needs of the inmate's family, the level of service required to meet those needs, the social agencies currently engaged in providing for some of those needs, and to ascertain the extent of interagency communication, cooperation, and coordination mong agencies providing services for the same famlly. Comparison of the areas of need as 1dentified by the family with the perceptual needs of the peisoner would be interesting and useful. 
ConcIusion

If the correctional program in Multnomah County is to involve treatment, rehabilitation, education, prevention and research, then the helping professions, especially those directly involved with the individual and his intraand inter-personal relationships, (e.g., Social Work) must exert greater influence and leadership in this program. If corrections is not solely the responsiblilty of a law enforcement agency but also the responsibility of a.1 privete and public social agencies and citizens, then soelal work must play an active role.

The study identified various areas of unmet needs confronting incarcerated men both within and without the Institution of confinement. Although the primary purpose has been achieved, the project should not be regarded as complete. The nature of the results seem to indicate that more extensive evaluation should follow. Therefore, it is hoped that the findings and recommendations herein reported might be given immediate consideration by social workers, public and private agencles concerned with planing and working with Incarcerated and released men, graduate schools of social work, and other helping professions. The study has shown that even for a group of inmates in a relatively favorable situation there are many unmet needs of valous kinds, ranging from relatively small 
importance to serious. Tests show that it is possible for middle-class social workers to elicit these needs without infecting their own biases, but that care must be taken in asserting their valence.

It was shown that there are valld bases for inferring needs not recognized by the inmates. For instance, both apathy and resistance were found, Indicating readjustments before treatment could be facilitated.

It was further shown that the men, the institution, and the community lacked the racilities to meet the needs of the men appropriately.

There was a wide range of Individual differences in needs and in ability to cope with them, indicaing an Individualized approsch as destrable if not indeed necessary. 


\section{NOTES TQ CHAPIER IX}

1. Report of the Priorities Committee, Portland, Oregon, October, 1962, p.2.

2. Tb1d., p. 41 .

3. Ibid.

4. Io1d.

5. Iold。 
Theory and Background

Barnes, Harry Elmer and Teeters, Negley, New Horlzons in Criminology, 3rd Edition, Prentice-Hall, Inc., Englewood CIIffs, New Jersey, 1959.

Chase, Stuart, "American Values: A Generation of" Change". The Public Opinion Quarterly,

Vol. XXIX, No. 3, FaII, 1965, PP. 368-376.

Clemmer, Donald, The Prison Community, Rinehart, New York, 1940.

Cressey, Donald $R$. . The Prison, Holt, Rinehart, and Winston, Inc., New York, 1961.

Dressler, David, Readings in Criminology and Penology, Columbia University Press, New York and London, 1964.

Elliott, Mabel A., Crime in Modern Society, Harper and Brothers, New Tork, 1952.

Q1bbons, Don C., Chang1ng the Iawbreaker, The Treatment of Delinquents and Criminals, Prentice-Hali, Inc.. Englewood CIIIT', New Jersey, 1965.

Giaser, Daniel, The Effectiveness of a Prison and Parole System, the Bobbs-Herril Company, Inc., Indianapo113, Ind., 1964.

Gleuck, Sheldon and Gleuck, Eleanord, Ventures in Criminology, Selected Recent Papers, Harvard University press, Cambridge, Mass., 1964.

Hearn, Gordon, Theory Bullding in Soclal Work, University of Toronto Press, Toronto, 1958.

Howard, D. I., John Howard: Prison Reformer, Archer House, Inc., New York, 1963.

Naess, S1r1, "Comparing Theories of Criminogenasis", Joumal of Research in Crime and Delinquency, ซol. 1. No. 2, July 1964, pp. 171-188. 
Queen, Stuart Alfred, The Passing of the County Ja11, George Bante Publishing Company, Menasha, Wisconsin, 1920.

Robinson, Louis N., Ja1ls, Care and Treatment of Misdemeanant Prisoners in the United States, The John C. Winston Company. Philedelphia. 1924.

Shaw, George Bernard, The Crime of Imprisonment, Philosophical Library, New York, 1946.

Smith, Robert C., "The Rature of Criminal Behavlours", American Journa I of Corrections, Vol. 25-36, No. 6, November-December 1963-64, pp. 26-29.

Sutherland, E. H., and Cressey, Donald R., Principles of Criminology, 5th Edition, Lippincott. Phlladelphia, 1955.

Turk, Austin T., "Prospects for Theories of Crimina I Behaviour"." The Journal of Criminal Law Criminology and Pollce Sclence, V01. 55, Wo. 4, 1964, pp. 454-461.

Tyler, Alice Felt, Freedom's Ferment, Harper and Row, New York, 1944.

Vold, George B., Theoretical Criminology, Oxford Univers1ty Press, New York, 1958.

Wines, Frederick Howard, Punishment and Reformation, Thomas Y. CroweII Company, New York, 1923.

Theory: Psychosocial Behavior

Erikson, Eric H., Ego and the Identity Cycle, International Universities Press, Inc., New York, 1959.

Lelghton, Alexender $H_{,}$Clausen, John $A_{.}$, Hlson, Robert N. Explorations in Soc10l Psychiatry, Basic Books, Wew York, 1957. 
Theory: Socili Work

Hamilton, Gordon, Theory and Practice of Soc1al Work, Columbia University Press, New Tork, T954.

Hol11s, Florence, Casework: A Psychosoclal Therapy, Random House, New York, 1964.

Mencher, Samue1, "Principles of Soc1al Work Organization". Soc121 Casework, Vol. 44, No. 5, May 1963, pp. 262-266.

MIIner, John C., "Preedom and Authority in Social Work", Soclal Work Papers, Vol. 8, The School of Sociel Work, University of Southern Cal1fornia, 1961 .

ONN11, Carle F., "Intens1ve Casework with Captive Clients". Social Casework, Vol. 40, No. 9 , November, 1959, pp. 486-491.

Overton, Allce, "Establishing the Relationship in Social Work" Crime and Delinquency, Vol. 11, No. 3, July i965, pp. 229-238.

Regensburg, Jeanette, "The Curriculum Study: Implications for the Practice of Social Casework", Soc 1a 1 Casework. Vol. 41, No. I, January í60, pp. 13-18.

S1lver, Joseph R., "C1tizen Participation in the Fléld of Corrections", American Correctional Association, Portiand, Oregon, 1963, pp. 80-85.

Studt, El11ot, A Conceptus 1 Approsch to Teaching Herlals: Iilustrations from the Field of Corrections, Council on Social Work Bducation, New York CIty, 1965.

Studt, Elliot, Education for Soc1al Workers in the Correctione I FleIa, CouncII on Soc1al Hork Education, Vol. 5, New York C1ty, New York, 1959.

Studt, E111ot, "Worker-CI1ent Authority Relationships in Soclal Work", Soclal Work, Vol. 4 , No. 1, January 1959, pp. 18-28. 
Methodology

Allen, Allce, et al, "Use of the Depth Interview in Examining Attitudes of Delinquent Boys: An Exploratory Study", A Group Project, School of Soclal Work, Portland State College, Portland, Oregon, 1964 .

Arkin, Herbert, and Colton, Raymond $R_{\text {. . Statistical }}$ Methods, 4 th Edition, Barnes and Noble, New Fork, 1939.

Current Projects in the Prevention, Control, and Treatment of Crime and Delinquency, VOI. IV, National Research and Information Center on Crime and Delinquency, National Council on Crime and Delinquency, New York, 1964.

Kahn, Alfred $\mathbf{J}_{\text {, }}$ "The Design of Research", Soc1al Work Research, University of Chicago Press, Chicago, 1960.

Mark, Hary Louise, Statistios in the king, Ohio State University. Columbus, 1958.

Morgan, Ralph W., "The Extension of Casework Principles into Questionnaire Construction", Social Casework, Vol. 40, No. 1, January, 1959, pp. 27-32。

Rozyck1, Jerome Joseph, "Early Rec1divism Among First Offenders", Doctoral Dissertation, The Catholic University of America, Washington, D. C., 1948 .

Case, John D., Major, USMC (Retired), "Modern Corrections in an Old County Jail", American Journe 1 of Corrections, Vol. 27, No. I, January-February 1965 , pp. 4-9.

Clark, Donald E., Letter to Kultnomah County Civil Service Commission, Portland, Oregon, June 7,1965 . Copies avaliable at office of Sheriff. 
Correspondence Course for Ja1lers, In1ted States Bureau of Prisons, \#1 to \#10. Pamphlets ava1lable through American Prison Association, Department of Ja1ls, Washington, D. C., n.d.

Frledman, Sidney, and Esselstyn, T. Conway, "The Adjustment of Children of Jall Inmates". Federal Probation, Vol. 29, No. 4, December 1965. pp. 55-59.

Q111, Howard B., "What is a Community Prison?", Federal Probation, Vol. XXIX, No. 3, September 1965, pp. 15-18.

Glaser, Donald, Zeman, Eugene S., and Dean, Charles W., Money Against Crime, A Survey of Economic Assistance. Wimeographed. John howard Association, Chicago, Illinols, n.d.

Inmate Manual, M.C.C.I., County of Multnomah, Sherift's office, 1963.

Moshofsiky, William V., Letter to the Honorable Tom MeCali, Secretary of State, 2-3-65. Coples avallable at Oregon Council on Crime and Delinquency, Portland, Oregon.

Purpose, Organization, and Departments, Multnomah County Sheriff's Orifice, Portiana, Oregon, 1965.

Price, Ray R., and La Ped1s, Edwin R., "Ja1l Inmates also are People who need People", Pederal Probation, Vol. XXIX, No. 3, September 1965. pp. 29-35.

Rubington, Earl, "The Alcoholic and the Ja11", Federal Probation, Vol. XXIX, No. 2, June 1965, po. 30-33.

Sanderson, W1IIIam and Olmos, Robert, "Series of Articles on Portiand Jalls". The Oregonian. (Portland, Oregon): The Sunday Tregonian Porum, $p .1$, col. 3 through 6 , November 28 , 1965; section III, p. 6 , col. 4 through 6 , November 29, 1965: Section III, p. 16, col. 1 through 8, November 30, 1965; Section I. p. 24, c01. 1 through 8, December 1, 1965; Section II, p. 48, col. I through 8, December 2. 1965. 
Service Report, John Howard Association, Ch1cago, III., 1964: (Mimeographed)

Standard Act for State Correctional Services, Proposed Final Draft' mimeographed report ava11able at Oregon Counc1I on Crime and Delinquency, Portland, Oregon, 1965.

Tinsley, Harry $C_{.}$, and Hunter, Harris $G .$, "Summary of Pre-release Procedures". American Correctional Association, 1962, pp. 180-183.

Walen, R. P., and Lyons, V. A., "Medical Problems of 500 Prisoners on Admission to a County Ja11", Public Health Reporter, Washingtion, D。C., Vol. 77, No. 6, 1962, pp. 497-502.

Za Iba, Serap10 P., Women Prisoners and thelr Families, Monograph, State of Calirornia, Departments of Public Welfare and Corrections, Delmar Publishing Co., 1964.

Post-Care of the Misdemeanant orfender

Andry, R. G., The Short-term Prisoner, Vol. 8 of the Libraxy of Criminology; Delinquency \& Deviant Social Behaviour, Stevens \& Sons, Lond on, 1963.

Court Services for Families and Children in Oregon. $A$ survey by the National Councli on Crime and Delinqueney, December 1965.

Heimler, Eugene, "Looking Behind Cold Facts", New Soc1ety, reprint, Apri1 18, 1963, p. 5.

Kennedy, Robert F., "Halfway Houses Pay Off" Crime and Delinquency, $\nabla 01.10$, No. 1 , January, 1964, pp. 1-7.

McHilian, David R., "Work Purlough for the Jalled Prisoner", Federa I Probation, V01. XXIX, No. 1, March 1965, pp. 33-34.

Olsen, Elmer, W., Supervisor, Correctional Casework, Trainee Untt, Paxole and Communtty Services Division, Deperiment of Correction, dakland, California. Letter to Sister Wary Patrick O Meara. Coples avaliable in Corrections Project Plies, Portland State College, Portland, Oregon, November 9, 1965. 
Pxlorities Cormittee Report, Portiend Community Council, 1902. Mimeographed copies avallable Community Council, Portland, Oregon.

Robinson, Cyril D., "Alternatives to Arrest of Lesser Offenders". Crime and Delinquency, Vol. II, No. 1, January, 1965, pp. 8-21.

Sullivan, Clyde, Grant, Marguerite Q., and Grant, J. Douglas, "The Development of Interpersonai Maturity: Applications to Delinquency", Psych1atry, Nov., 1957, p. 373.

Treger, Harvey, "Reluctance of the Social Agency to Work with the orfender" Federal Probation, Vol. XXIX, No. 1, March 1965, pp. 23-28.

We11, Thomas P., and Price, Charles P., "Alcohollsm In a Metropolitan City: A Suggested Comprehensive Rehabilitation Program", American Correctional Association, Philadelphla, Pennsyivania, 1962, pp. 103-118.

Where to Turn, A D1rectory of Health, Welfare and Recreation agencles, prepared by the Communtty Counc11, Portland, Oregon, July, 1964.

Hille, Lols, "Money against Crime", Pederal Probation, Vol. 26, No. 4, December 1962, pp. 34-38, 
APPENDICES 
APFENDIX A

What Can I Call You?

Date

Age

Pace of B1rth

(Ask a few questions not on questionnaire) 
QUESTIONDHA IRE - CORRECTIONS

Interviewer

FARTLY SITUATION. -..-.-

DEtg

1. a. Never married

b. Engaged

c. Married

d. Common-law

0. Was Ilving with wife?

f. Will be living with wife?

g. Was living with mom not wife?

h. Will be living with woman not wife?

1. D1vorced?_WL_ (No, of times)

1. W1dowed? (Mo. of times)

k. Othex

2. Supporting

a. 敞fe?

D. Exwlfe?

c. Parents?

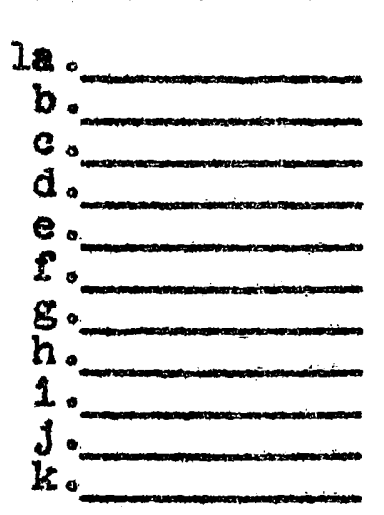
do Chtidren?
e. Other
d. Chtldren?
e. Other

3. Do you have children? Number? $3.1 \%$

2. $0-100$

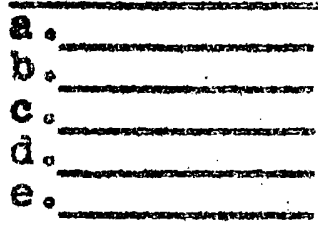
Ages and sex (male) (Feme) 


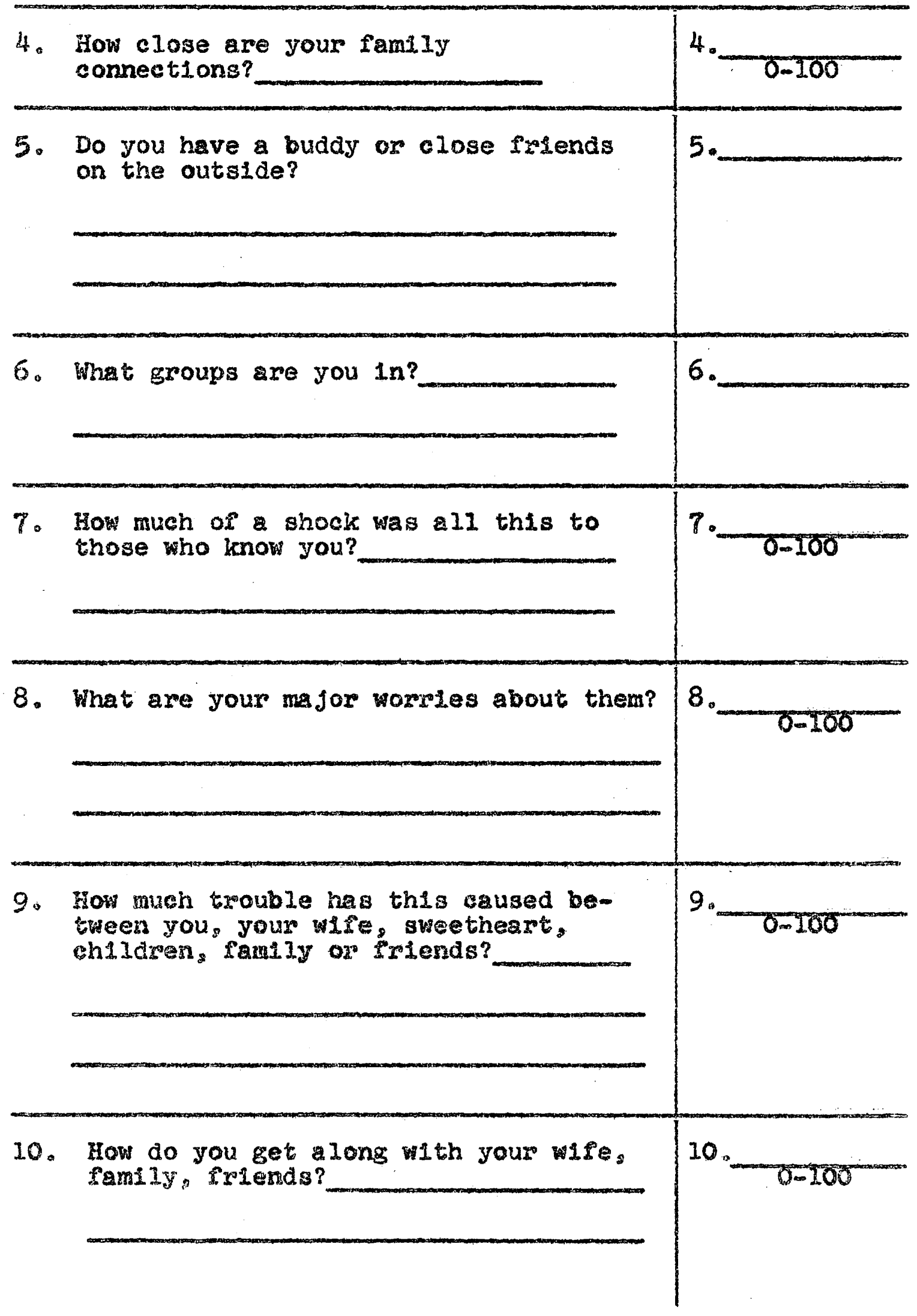


11. What is or was the problem in your marriage?

a. Childzen

b. Discipliñe

c. Helping

d. In-laws

e. Sex

f. Alcohol

B. Housing

12. How serious was this problem?

12 .

11 .

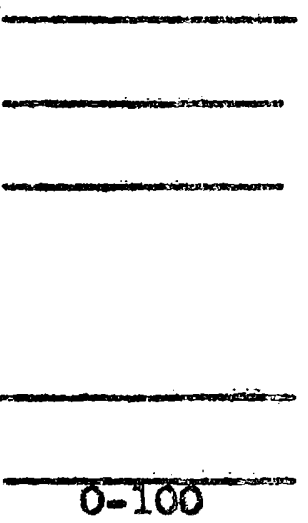

13. Do Jou have a job to go to?

13. Yes

No.

Majbe

14. What kind of woriker are you?
a. Skilled
b. Sem1-sitiled
. Casue1

15. Is your line of work

(a) Steady

(b) See s ona I

c) odd Jobs

16. a. How well does your line of work pay?

(1) Monthly

b. How well does it cover your needs?
(1) Entirely
(2) Above average
(3) Below average

14

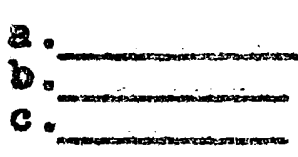

25.

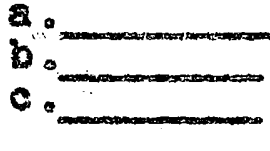

162

Anmus I

b.

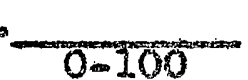

27. To what town and county w111 you go wher you get out?

17.

18. With whom w111 you Itve?

18. 
19. How long can you stay?

19.

20. How good are the living arrangements? 20.

SOCIAL CONTACTS. .......

21. What things do you like to do best

in your spare time? (List in order

of Importance - highest first)

a.

b.

c.

a.

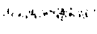

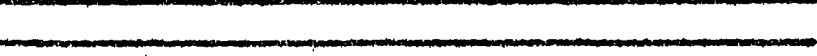

21

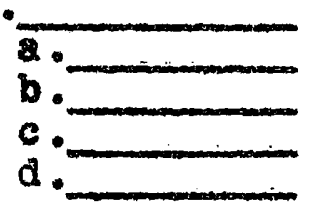

22. W1th whom do you prefer doing this?

a. Wife

b. Ch1laren

c. Friend

d. Relative

e. Alone

fo other

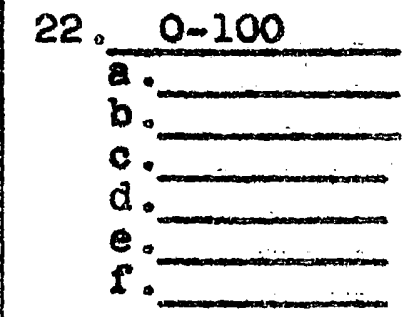

23. When you need to talk things over, 23 is there any one special you go to?

a. Why?

a.

\begin{tabular}{l|l|l}
\hline 24. Who is most helpful to you? & 24. \\
\hline 25. Who is least helpful to you? & 25. \\
\hline
\end{tabular}




26. How easy has it been to get the
help you or your family needs?
(Scale, difflcult to easy)
$\begin{array}{ll}\text { a. Religlous } & \text { d. Money } \\ \text { b. Medical } & \text { e. Legal } \\ \text { c. Job } & \text { f. Other }\end{array}$

27. How much would you like it to have people come in here and tell where and how to go about helping yourself? (Scale, Not much-Very much)

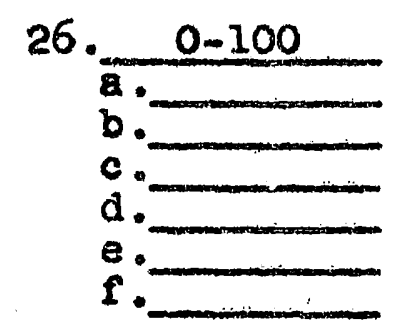

27.

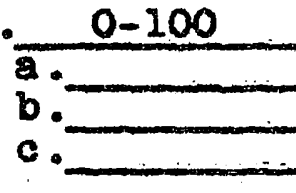

28. What would you like to have them 28. talk about?

29. How often do you turn to your church for help?

29.

$0-100$

30.

$0-100$

30. How much help do
church could be?

think the

(0.200

31. Do you have a priest/minister to whom you turn for help?

31.

INCARCERATION.

32.13 there anything about being here at MCCI that especlaliy bothers you?
a.
b.
c.
d.
e.

32.2.

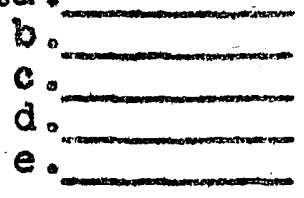


33. How much does this bother you?

33.

$0-100$

35.

35. How do you feel
situation here?

about visiting $0-100$

36. How do you feel about the postal (ma1) situation here?

36. $0-100$

37. How do you feel about the recreation program here?

37. 0.100

\&OST RELEASE.

38. What are you going to need the day you are released?

38.

39. How are you golng: to get them?

39.

40. What program or staff member helps

40. you in maklng plans for meeting these needs?

.

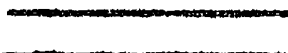


41. In the long run, what do you see your needs are going to be when you are released? (Probe)

a. Job

b. Money

c. Housing

d. Clothing

e. Pamily

(Wife)

Chlidren

(Other)

f. Educational

g. Medical

h. Recreation

1. Religious

J. Legar

k. Fine

1. Garnishee

M. License
41. $0-100$

a.

b.

c.

d.

e.

f.

B.

h.

1.

J.

k.

1 .

m. 
n. Amount of Money

o. other____

a.

○.

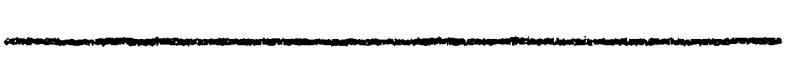

42. How Important is this to you?

42

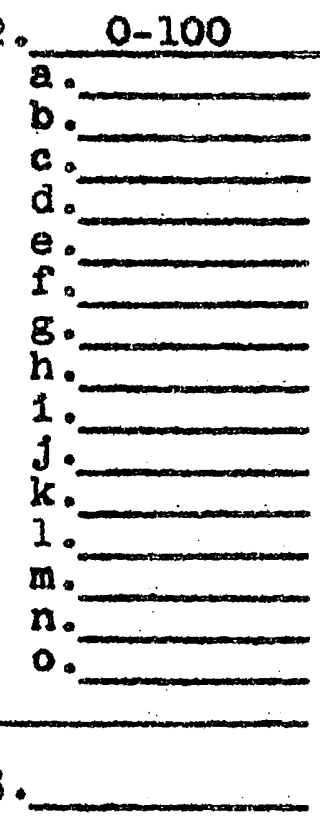

43. Have you had trouble wth this in the past?

43.

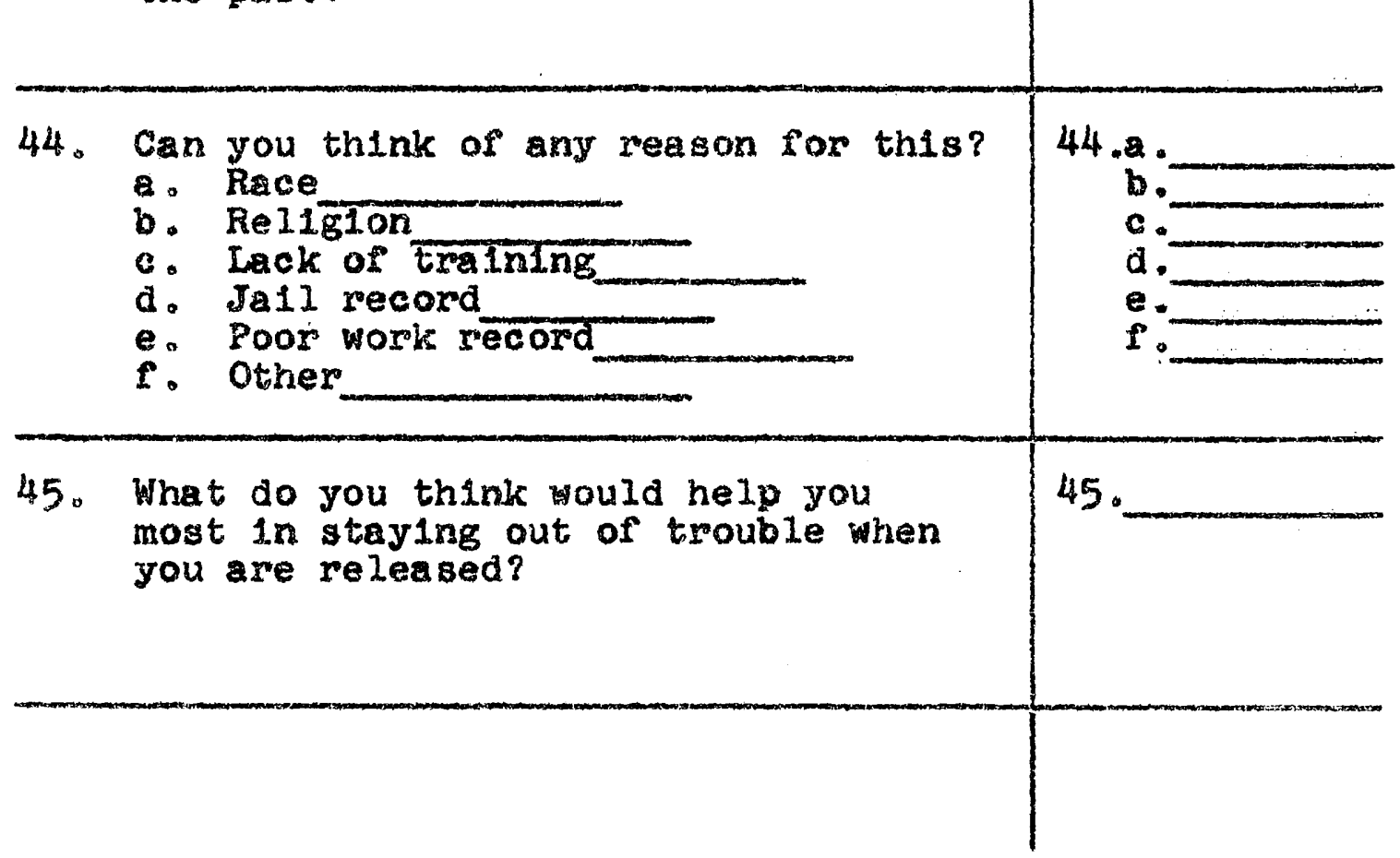


46. Do you think it would help to have a list of places (agencies) or people who could offer you services or counseling when you get out?

a. What would you guggest?

46.

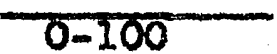

a.

47.

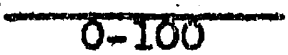

47. When you are released, do you think it would help if you could join a group dealing with your type of problems?

48. Do you know of an ageney which could help you with your type of problems?

a. W111 you use it when you get out?

48.

a.

49.

49. Have you received help from a soctal agency in the past?

50. Which one?

50.

EDUCATION.

51. Do you often think additional education or training would help you?

a. How much?

52. What plans do you have?

52.

a. 0.100 
53. What do you need to put this plan through?

a. Vocational training?

b. Academic training?

c . Other?

53.

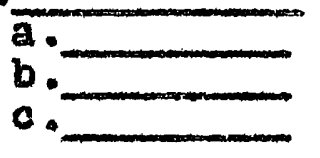

\section{SELS-CONCEPT}

54. Generally how is your health?

Very poor__ Poor_aood

Very good

a. Llst any problems.

55. Do you usually get along with people?

55.

a.

54.
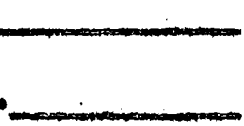

$0-100$

56. Do you think most people like you?

56.

$0=100$

57. What are the main things you worry about?57.

a. Parents

b. Job

c. W1fe

d. Children

a Girl friend

I. Nioney

g. Other

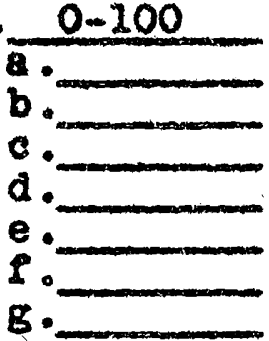

58. Why do you think you have trouble with the law?

a. People you go with?

b. Drink too much?

c. Melghborhood you IIve In?

d. Past record?

e. Other?

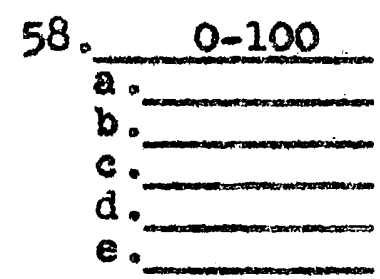


59. How much does being in trouble with the law bother you?

59.

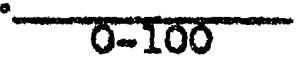

60. In what areas does it bother you?

60.

61. What do you think would help you most $r, 1)$ stay out of trouble?

a. Becter understanding of self?

b. Gritting along with people?

c. Sielp for a soclal agency?

a. Help from a priest/minister?

e. More education?

s. Ab1lity to hold a job?

g. Other?

62. How hard have you tried to do anything about this?

61.

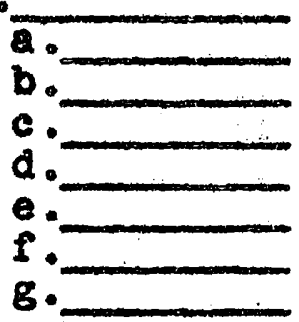

62.

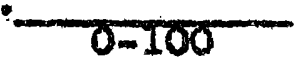

63. What bothers you most about yourself?

a. Physlcal appearance?

b. Mental abilities?

c. Personal appearance (grooming)?

d. Self-consclousness?

e. Agressiveness?

f. Lack self-confidence?

g. Other?

63.

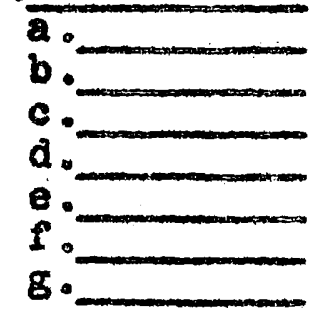


64. How much does this bother you?

64. $0-100$

65. How hard have you tried to
overcome this?

66. In what way?

a. Talk to others?

b. Social Agency?

c. Counselor?

d. Teacher?

e. Other

67. What do you think you are good at?

a. Physica I skil1a?

b. Personality?

c. Leadership?

d. Morel qualities?

e. Mental abilities?

f. Other?

67.

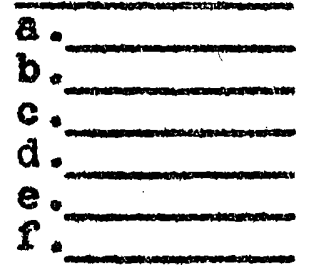


68. How good?

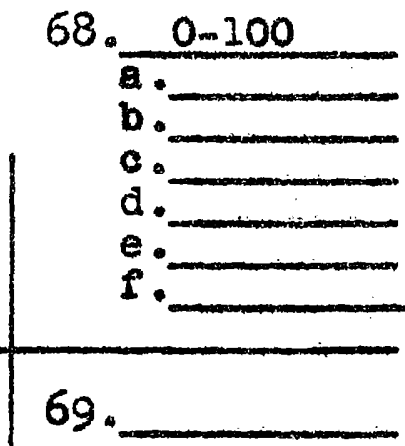

69. What do you think needs to be streng thened so you 11 get along bettex outs1de of hexe?

70. Regarding your arrest and sentence to jail/MCCI, do you think you got - fair deal?

a. Unjustiy convicted?

b. Too heavy antence?

c. In what way?

70.

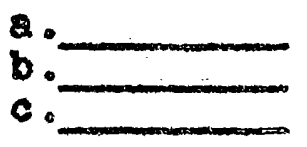

IMMATE EVALUATION.

In

71. Would you mord some of these questions differently?

71.

72. Would you use other types of questions?

a Suggestions not covered?

73. Do you have any other questions or suggestions about this study?

73.

72.

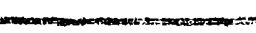




\section{SUMMARY OF QUESTIONNAIRE RESPONSES}

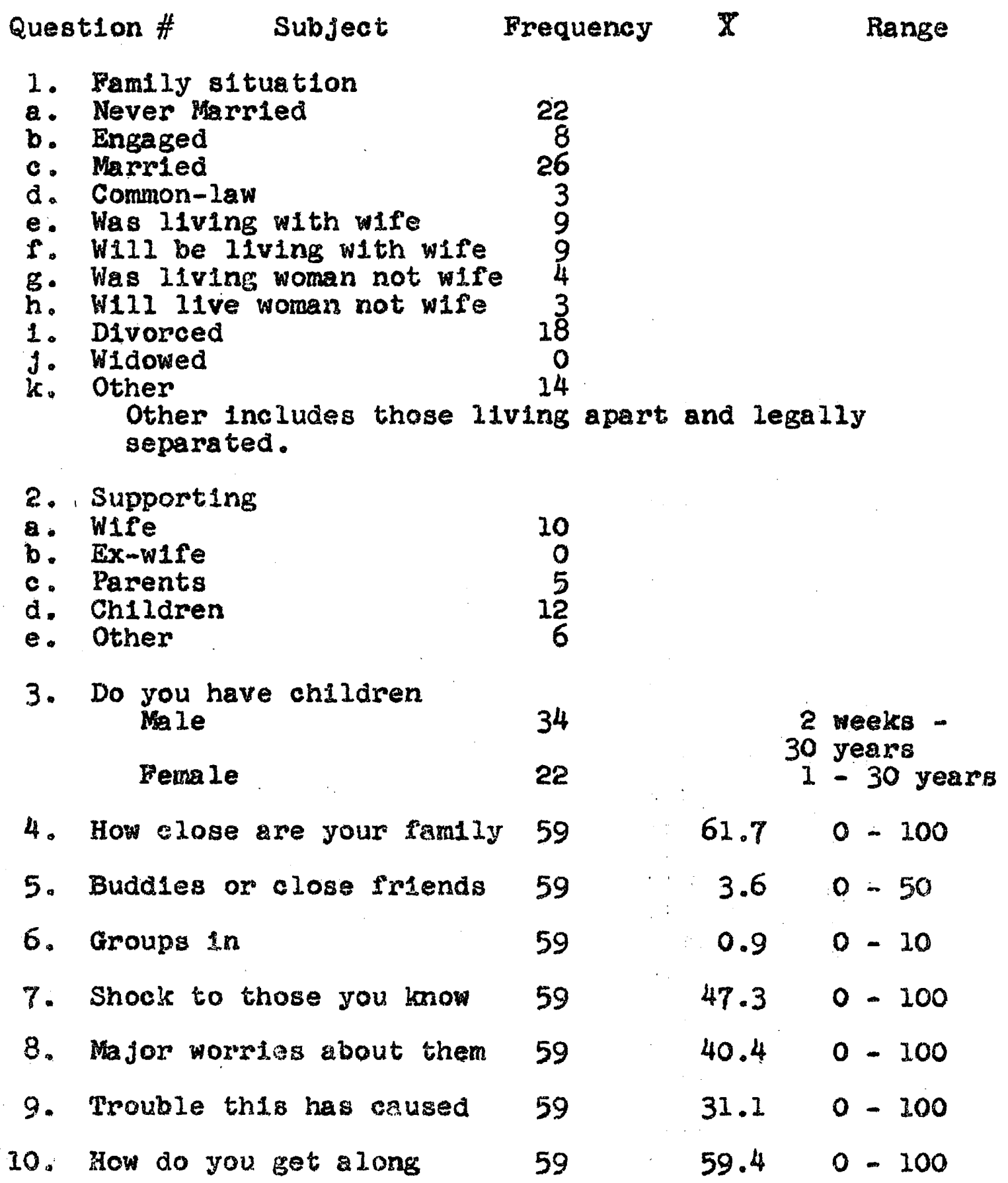


Question \# Subject Frequency $\bar{X}$ Range

11. 12. Problems in marriage 31

a. Children 1

b. Discipline 1

c. Helping 0

d. In-laws 8

f. Alcohol 20

g. Housing 6

h. Other 24

Other includes: absence in jail, prison, running

around 3; Religion 1; money 2; non-employment 2; wife 8

(working 1, grlping 3, Incompatiblilty 2, lesblan 1

drinking I); Irresponsibility 2; disposition 3; narcotics 1.

13. Have job to go to

Yes

No

Maybe

14. Kind of worker

Skilled

Sem1-skilied

Casua 1

15. Xind of work

Steady

Odd Jobs

Seasonal

16. Annual income Cover needs ent1rely

Above-average

Below-average

17. Town or county go to

Multnomah County

Oregon

Out of state

Don't know

18. Live with

Alone

Parents

Wife

Relative

Other
20

23

16

16

21.5

21.5

34.5
16.5

8.0

$49 \$ 4,472 \$ 200-18,000$

31

19

40

8

2

22

17

8

3 
Question \#

$$
\text { Subject }
$$

Frequency $\quad \mathrm{X}$

Range

19. How long can stay

Indef Initely

Less than month

Less than 6 months

Less than 12 months

Don't know

46
5
2
1
5

20. How good living arrangements

$\begin{array}{lr}\text { Good } & 22 \\ \text { Fair } & 21 \\ \text { Poor } & 1 \\ \text { Don't know } & 15\end{array}$

Social Contacts

21. Do in spare time: Active sports 76; (outdoor 44, indoor 23) Social activities 25; Shows and IV 16; Hunting and flshing 14; Cycling, flying, and driving 14; Spectator sports 11; Hobbles 10; Drinking 10; Music 9; Studying 3; Reading 2; and one each of riding zoo train, hunting Indian relics, inventing jlingles, sleeping, dominoes, cooking, painting, thinking, and traveling.

22.
Wife
ChIldren
Friend
Relative
Alone
Other
8
43
13
36

23. Talk to anyone

Yes

No

31

Who

28

Wife

Nuclear family

18

Extended family

Minister or priest

Friends

Psychlatrist

No one

3

12

$\frac{1}{8}$ 
Question \# Subject Frequency $\mathbb{X}$ Range

24. Who is most helpful
Parent or parents
Relative
17
Professional
15
Friend
17
Other
12
"Other" Includes no one, self, legal guardian, employer, and don't know.

25. Who is least helpful
Parent or parents
Relative
Professional
Friends
Self
Other
30
"Other" Includes: no one, foreman at work, probation orficer, and don't know,

26. How easy to get help

a. Re11gious

b. Medical

c. Job

d. Money

e. Legal

f. Other

Never needed help

27. People come in and talk 59

28. What talk about

Genere I toplos
Counselling
Jobs and employment
Not interested

29. Turn to church for help 59

30. How helpful church can be 59

31. Priest or minister you turn to No

Yes

45

14
$71.80-100$

$78.4 \quad 10-100$

$69.010-100$

$65.85=100$

$61.90-100$

$65.0 \quad 0-100$

$51.30-100$

11.

29)

1

$9.10-90$

$36.10-100$ 
194

Question \# Subject Frequency $X$ Range

32. Things that bother at MCCI $59 \quad 60.2 \quad 0-100$

Lack of rehab.

Incarceration

Dislike authority

Other Inmates

Noise

No music inst.

Staff rules

Miscellaneous

4
8
34
9
9
4
2
5
6

(Worry, tension, ma11 censorship, food)

34. Like about at MCCI

$\begin{array}{lr}\text { General } & 30 \\ \text { Freedom } & 15 \\ \text { Dignity } & 9 \\ \text { Work } & 11 \\ \text { Recreation } & 16 \\ \text { Pood } & 13 \\ \text { Library } & 7 \\ \text { Ma11 visiting } & 5\end{array}$

$59 \quad 86.2 \quad 0-100$

35. Visiting situation

Satisfied

Dissatisfied

$\begin{array}{rrr}51 & 88.4 & 50=100 \\ 8 & 37.5 & 0=100\end{array}$

36. Ma11. situation

Setisfied

Dissatisfied

$\begin{array}{rrr}50 & 86.9 & 50-100 \\ 9 & 43.9 & 0=100\end{array}$

37. Recreation program

$59 \quad 79.9 \quad 40-200$

38. Colng to need day of release

Nothing

Money

Lodging

19

Food

Clothing

Job 22

Other 12

"Other" Includes: Ride to town a car, transportation, treatment, a woman, and "A drink and a girl".

39. How going to get them

Find employment

Self

21

Family

Friends

Soc1al agency

No 1dea

14

13

4

10 
Question \#. Subject Frequency $\bar{X}$ Range

40. Staff or programs help you

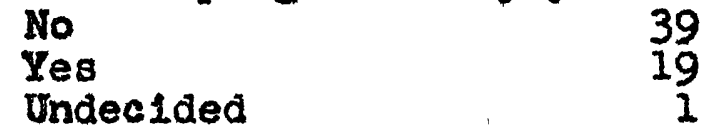

41. Iong range needs

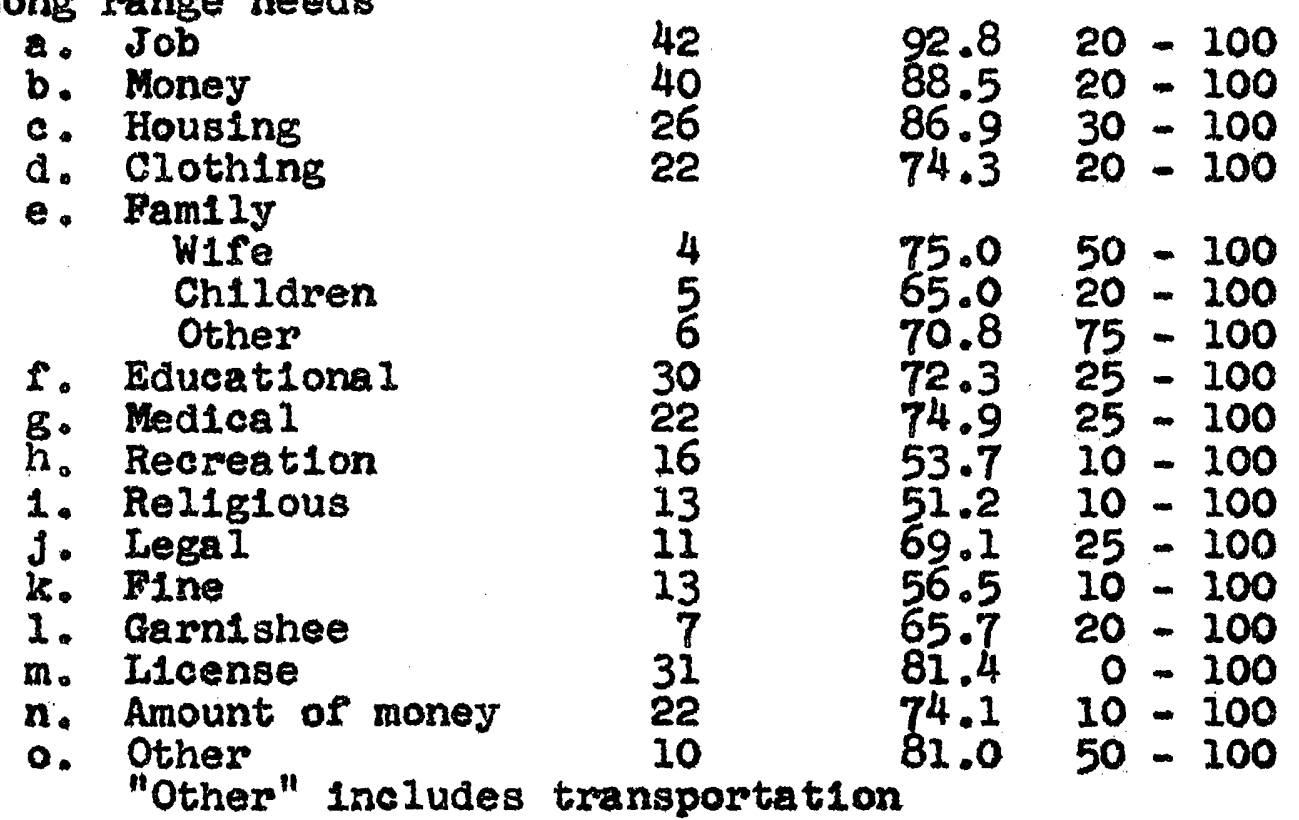

42. How Important to you

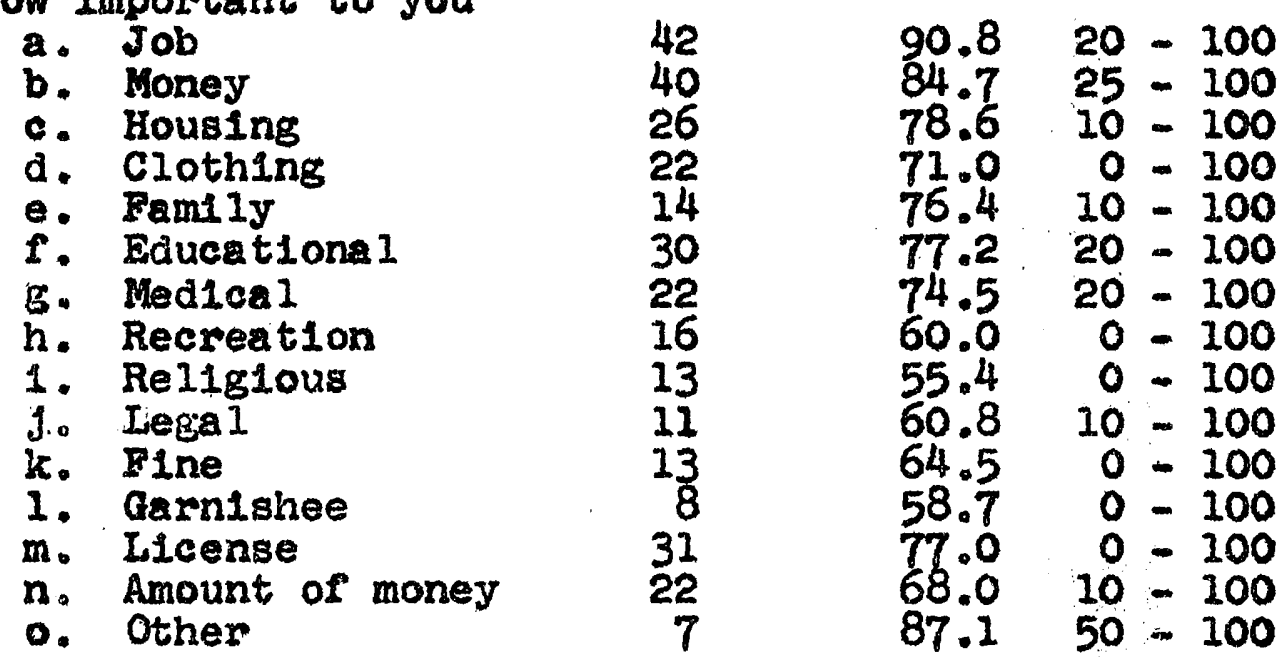

43. Trouble with these in past
a. 31
b. 28
c. 8
d. 10
e. 9

f. 8

g. 8

h. 5

1. 2

k. 8

1. 3

m. 21

n. 5 
Question \#

Subject

Frequency

$\overline{\mathbf{X}}$

Range

44. Reason for this trouble

$$
\begin{aligned}
& \text { 2. Race } \\
& \text { b. Religion } \\
& \text { c. Lack of training } 15 \\
& \text { d. Ja1l record } \\
& \text { e. Poor work record } 10 \\
& \text { f. Other } 6 \\
& \text { "Other" Included: Alcohol \& drugs, 13; } \\
& \text { Att1tudes, 13; Economics, 4; Wrong compan- } \\
& \text { lons, 4; Driving and past record, 4; } \\
& \text { Health, 2; and no answer, 9. }
\end{aligned}
$$

45. Help most stay out trouble

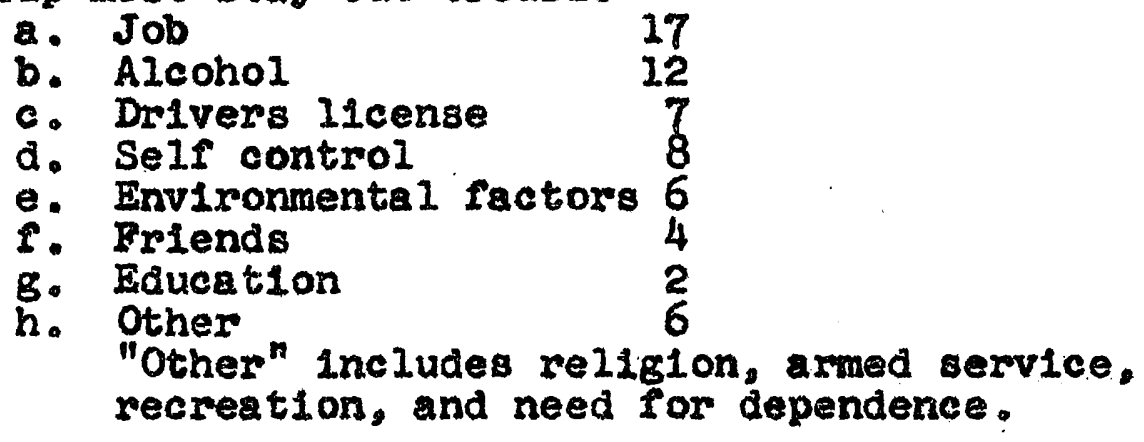

46. List of places help $59 \quad 45.1 \quad 0-100$
a Individua 1 counseling 5
b. Employrment
11
c. Lega I \& Inancial 3
d. Social agency 11

47. Help to join a group 59

$23.7 \quad 0-100$

48. Know an agency could help you $\begin{array}{ll}\text { Yes } & 17 \\ \text { No } & 42\end{array}$

W11l you try $1 t$

$\begin{array}{lr}\text { Yes } & 12 \\ \text { No } & 41 \\ \text { Paybe } & 6\end{array}$

49. Have agency help in past Yes No 
Question \# Subject Frequency $\bar{X}$ Range

50. Which one

$\begin{array}{lr}\text { Public } & 27 \\ \text { Voluntary } & 5 \\ \text { Health } & 5 \\ \text { Legal } & 1\end{array}$

Agencles 11sted were: Welfare, Indian agency, JDH, Farole and probstion, Huit. Co. Hospital, Dammasch Hospltal, MA, Salvation Army, Veterans administration.

51. Additional education help

$$
\begin{aligned}
& \text { Yes } \\
& \text { No }
\end{aligned}
$$

How much

52. What plans do you have

Vocationa 1

Academic

53. Need to put this through
a. Vooational training
b. Acedemic training
c. Other
Money 4
Motivation 2
Securelty
Time
No plans

54. How is your health

$\begin{array}{lr}\text { Very poox } & 0 \\ \text { Poor } & 6 \\ \text { Cood } & 37 \\ \text { Very good } & 16 \\ \text { oblems } & \\ \text { Dental } & 11 \\ \text { Physleal } & \\ \text { Permanent } & 10 \\ \text { Temporary } & 13 \\ \text { Emotiona 1 } & 2\end{array}$

55. Usua 11y get along with people

59

$76.925-100$

56. How people Iike you

59

$70.910-100$ 
Question \#

Subject

Frequency $\quad \mathrm{X}$

Range

57.
a. Parents
b. Job
20
c. Wife
d. ChIldren
e. Girl friend
f. Money
8. Other $\begin{array}{cc}28 & 82.7 \\ & 10\end{array}$
32
18
12
22
$69.05-100$
$89.030-100$
$73.7 \quad 30-100$
$86.9 \quad 40-100$
$77.6 \quad 15-100$
behavior 7; family 4; incarceration 6 ;
11cense 4; educetion 1 ; and housing, 1 .

58. Why have trouble with law
a. People you go with
b. Drink too much
19
$76.550-100$
c. Nelghborhood live in
d. Past record
31
e. Other
24
28
$90.620-100$
$79.425-100$
$66.7 \quad 10-100$

"Other" Included: Ant1-social behavior 16; Unlicensed driving 7; Race 2; Marrlage 1; and other 1.

59. Trouble with law bother you59

$62.10-100$

60. In what areas bother you

$\begin{array}{lr}\text { Self } & 24 \\ \text { Family } & 10 \\ \text { Friends } & 2 \\ \text { Other (pollce methods) } & 1\end{array}$

61. Help most stay out trouble

a. Better understanding of seif 23

b. Getting along with people il

c. Help from social agency 11

d. Help from priest or minister 10

e. More education 20

f. Ablilty to hold a job 18

8. Other 31

"Other" Included: Self Improvement 22; and Social responsibility 7 .

62. Tried to do something about $49 \quad 48.1 \quad 0-100$ 
Question \# Subject Frequency $X$ Range

63. 64. Bothers about self

a. Physical appearance $9 \quad 71.6 \quad 25-100$

b. Mental abilities

c. Personal appearance 3

d. Self-consclousness 20

$54.620=90$

$\begin{array}{ll}\text { e. Aggressiveness } & 20 \\ \text { f. Lack self-confldence } 20\end{array}$

$43.3 \quad 30-50$

$67.125-100$

f. Leck self-confidence $20 \quad 65.4 \quad 10-100$

g. Other $27 \quad 79.6 \quad 10-100$

"Other" Included: Impulsive behavior 9; Irresponsibility 9; Lack of training 2; and low self concept 4 .

65. Tried to overcome this

$\begin{array}{lrll}\text { a. Physical appearance } & 8 & 40.6 & 0-100 \\ \text { b. Mental abilities } & 6 & 21.6 & 0=100 \\ \text { c. Personal appearance } & 3 . & 27.0 & 0=80 \\ \text { d. Self-consciousness } 20 & 49.4 & 0=100 \\ \text { e. Agrressiveness } & 20 & 38.3 & 0=100 \\ \text { f. Lack self-confidence } 18 & 43.2 & 0=100 \\ \text { g. Other } & 22 & 40.7 & 0=100\end{array}$

66. In what way
a. Talk to others
16
b. Soclal Agency
8
c. Counsellor
d. Teacher
e. Other
*ost-In "othex" should have been included in - taik to others (66a)

67. \& 68. What good at and how good

$\begin{array}{llll}\text { a. Physical sk11is } & 44 & 76.2 & 50-100 \\ \text { b. Personality } & 29 & 72.4 & 25-100 \\ \text { c. Leadership } & 27 & 59.6 & 25=100 \\ \text { d. Moral qualities } & 30 & 70.2 & 30=100 \\ \text { e. Mental abilities } & 28 & 71.2 & 30=100 \\ \text { f. Other } & 15 & 86.7 & 50-100\end{array}$

69. What needs strengthened

Better understanding

Vocationa 1 and Educationa 37

70. D1d you get fa1r deal

Yes

37

No

21

Unjustiy convicted

Too heavy a sentence

Police methods unfair

Record prejudiced 
APPENDIX C

Chart 1

In tes by Age

$\begin{array}{lll}25 \text { or under } & 34 \\ 26 \text { to } 40 & & 14 \\ 41 \text { to } 62 & & 12 \\ \text { Mean } & \text { Total } & 60 \\ \text { Range } \quad 29.5 & \\ \text { Mang } 62 & \end{array}$

Chart 2

Inmate Education

1 to 9 years

10 to 12 years

13 to 14 years

Total

36

68

Heludes 14 high school graduates

Mean

Range $\quad 2$ to 14 years

Chart 3

Length of Senterce

30 to 89 days

90 to 149 days

150 to 269 days

210 to 269 days

270 to 329 days

330 to 389 days

Over 390

5
5
29
2
1
16
2

*wo men vere serving consecutive sentences on two charges totaling over 390 days.

Mean 266.2 days Median 205 days

Range $\quad 30-730$ days Mode 180 days 
Chart 4

Inmate Offenses

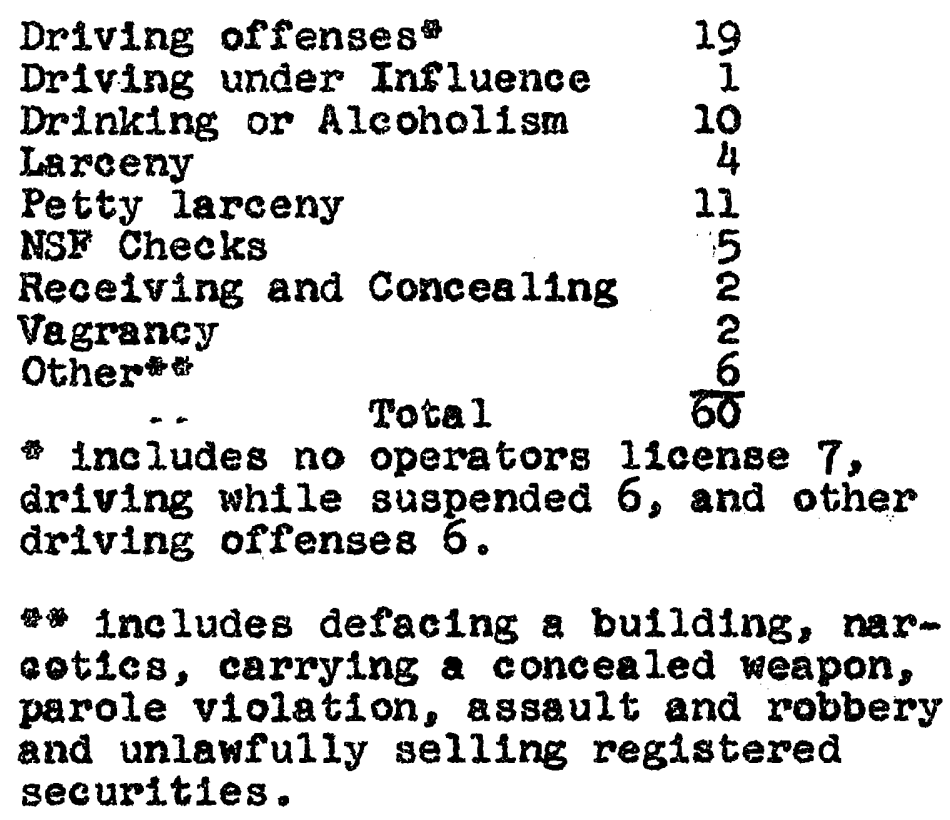

Chart 5

Annual Income fest.)

Under $\$ 1000$
$\$ 1000=1999$
$2000=2999$
$3000-3999$
$4000=4999$
$5000=5999$
$6000=6999$
$7000=7999$
$8000=8999$
$9000=9999$
over 10000

Chart 6

Kind of Worker (\#14)

Sk111ed

Semi-skilled

Casua 1

16

21.5

$21: 5 \%$

- One man considered himself to be in

- both categrries. 


\title{
Chart 7 \\ Kind of Work (\#15)
}

Steady

Odd-jobs

Seasona 1

Tota 1

34.5 뱅

16

$8.5^{\text {埇 }}$

59

* One man worked steady when possible otherw1se d1d odd-jobs. Another man did odd-jobs during winter months and was chlefly a seasonal worker.

chart 8

Job walting (\#13)

Yes

Mo

Mybe

\begin{tabular}{rr} 
& 20 \\
& 23 \\
Total & 16 \\
\hline & 59
\end{tabular}

Chart 9

Mrital status

Never Harried

Mrried at present

Living with wife

"Common Iaw"

living apart

23

59

$\quad 3.4$

\author{
Chast 10 \\ Parental Status \\ Number of men who are Pathers 23 \\ Number of children under 18 * 49 \\ Range 2 weeks to 17 years
}


Chart 11

Needs of Inmates ranked by Extensity with Intensity

Need

Meen

Exteng1ty

\# or

Mean

Job

92.8

Range Men

Intensity

Money

88.5

20-100

42

90.8

Housing

86.9

20-100

40

84.7

Jucense

81.4

$30-100$

26

78.6

Othert

81.0

$0-100$

31

77.0

Medica'

74.9

$50-100$

10

87.1

clothing

74.3

25-100

22

74.5

Amount Money Ored.

74.1

20-100

22

71.0

Educationa 1

72.3

$10-100$

22

68.0

Fans.1y

70.0

$25-100$

30

77.2

Lega 1

69.1

25-100

15

76.4

Garnishee

65.7

25-100

.11

60.8

Pine

56.5

20-100

7

58.7

Recreational

53.7

10-100

13

64.5

ReI1gfous

51.2

$10-100$

16

60.0

$10-100$

13

55.4

* Includes: 1 back support, 1 dental, 1 want to be free, 1 to own home, 1 budgeting, 1 transportation, 1 a wan, 3 not stated. 
Chart 12

Replies to Question 4la\#

Weed for a Job

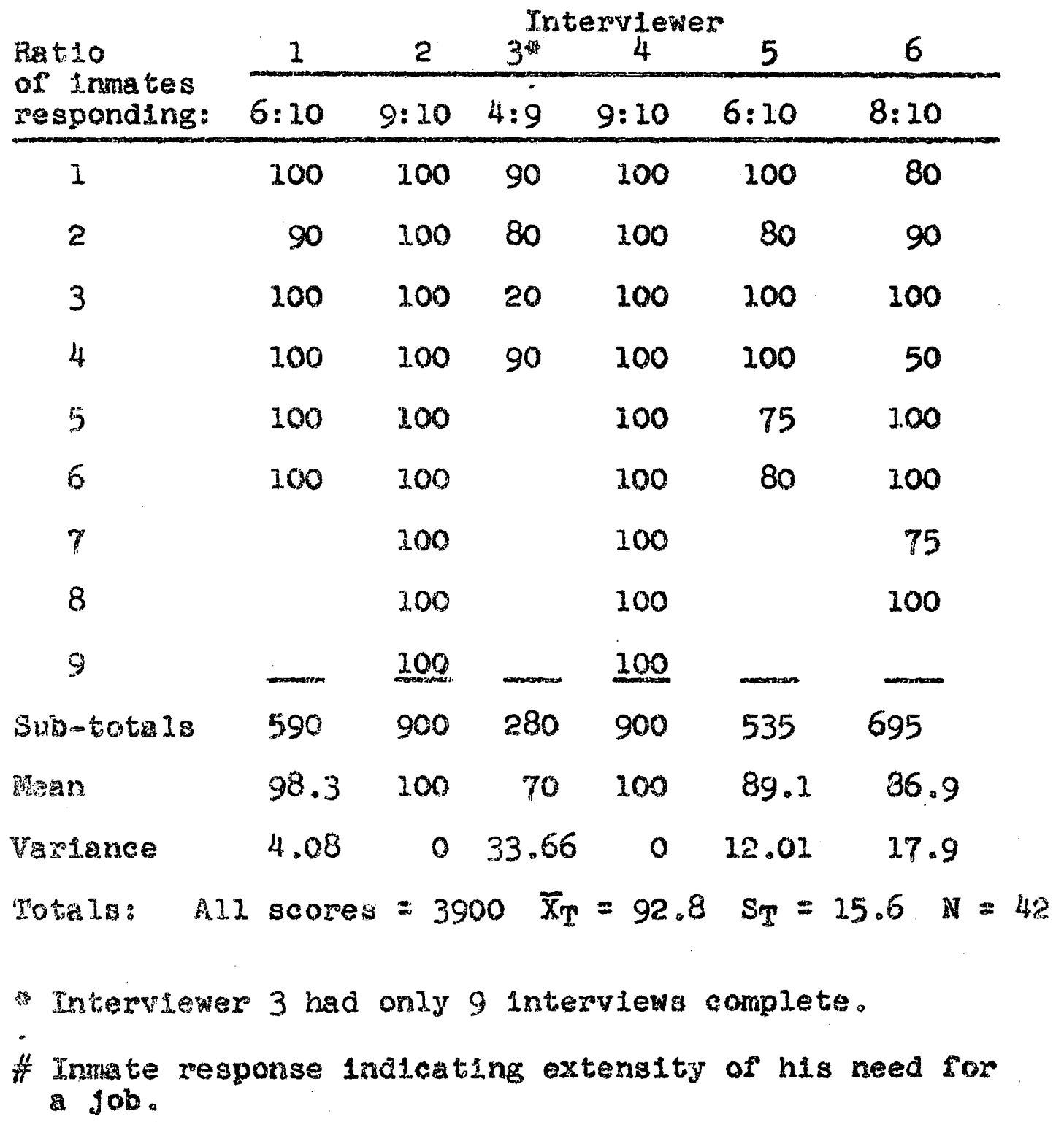

